SPHECIDAE AND POMPILIDAE (HYMENOPTERA)

COLLECTED BY MR. K. M. GUICHARD

IN WEST AFRICA AND ETHIOPIA

I 94 I-I 948

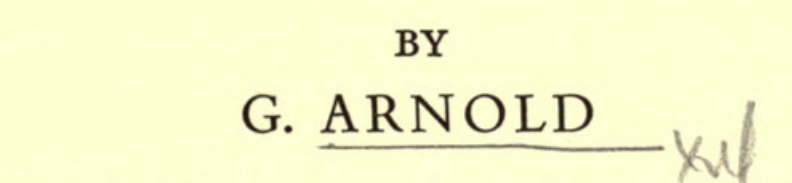

National Museum of Southern Rhodesia

Bulawayo

Pp. 95-183; Pls. 4-5; 65 Text-figures

\begin{abstract}
BULLETIN OF
THE BRITISH MUSEUM (NATURAL HISTORY) ENTOMOLOGY Vol. 2 No. 3

LONDON : I95I
\end{abstract}


THE BULLETIN OF THE BRITISH MUSEUM (NATURAL HISTORY), instituted in 1949, is issued in five series, corresponding to the Departments of the Museum.

Parts appear at irregular intervals as they become ready. Volumes will contain about three or four hundred pages, and will not necessarily be completed within one calendar year.

This paper is Vol. 2, No. 3, of the Entomological series.

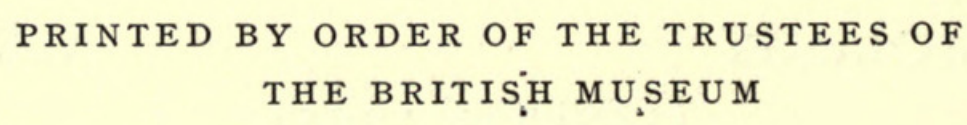




\title{
SPHECIDAE AND POMPILIDAE (HYMENOPTERA) COLLECTED BY MR. K. M. GUICHARD IN WEST AFRICA AND ETHIOPIA, I94I-I948
}

\author{
$B y$ G. ARNOLD \\ PART I. SPHECIDAE
}

THIs paper is based on a collection of nearly 700 specimens which Mr. R. B. Benson of the British Museum has submitted to me for study. It is of considerable interest, since it is derived from regions from which there have been few new records within at least the last fifty years. The great majority of the species from West Africa known up to the date of Dalla Torre's Catalogus Hymenopterorum, I897, were made known chiefly by F. Smith and F. F. Kohl, and after that date by R. E. Turner. The proportion of new species is considerable, especially of the Cercerinae. On the other hand, the tribes Miscophini, Psenini, and Pemphredonini, of which the members are small or very small, are barely represented.

In the following list of species I have given only the original reference, which in many cases applies to only one sex. For descriptions of the other sex, if known, the reader should refer to my monograph of the African Sphecidae published in the Annals of the Transvaal Museum, 9-14, I922-I93I, and to several papers published in the Occasional Papers of the National Museum of Southern Rhodesia.

Types of new species are in the British Museum.

The least magnification required to resolve the sculpture with a stereoscopic binocular microscope is indicated in brackets, e.g. (40 diameters).

\section{Subfamily TRYPOXYloninaE}

1833, Ann. Soc. Ent. Fr. 2: 408.

Pison xanthopus Brullé

Kpeve, Gold Coast, June I942, I ô.

1906, Spolia Hymen.: 213.

\section{Pison allonymum Schulz}

Haramaia, Ethiopia, June I948, I ㅇ․

Pison montanum Cameron

I910, Sjöstedt's Kilimandjaro-Meru Exped. 8: 289.

Dilla (Sidamo) Ethiopia, June I948, 2 హో.

Trypoxylon viduum sp. $\mathrm{n}$.

(FIGS. I, I $a-c$ )

๙. II mm. long. Black. Wings hyaline, slightly smoky beyond the cells. Clypeus 
and face up to the scutate area, and the temples with silvery, the occiput with short and black pubescence. Thorax with the usual whitish and erect pubescence, nowhere dense. Clypeus twice as wide in front as long, the anterior margin feebly convex. Facial shield entire, slightly longer than wide across the lateral angles, from which is emitted a carina extending over the inner half of the ocular sinuses. The shield is closely punctured, the punctures largest at the sides, the interspaces about as wide as the punctures. Behind the scutate area but not reaching the posterior ocelli, the
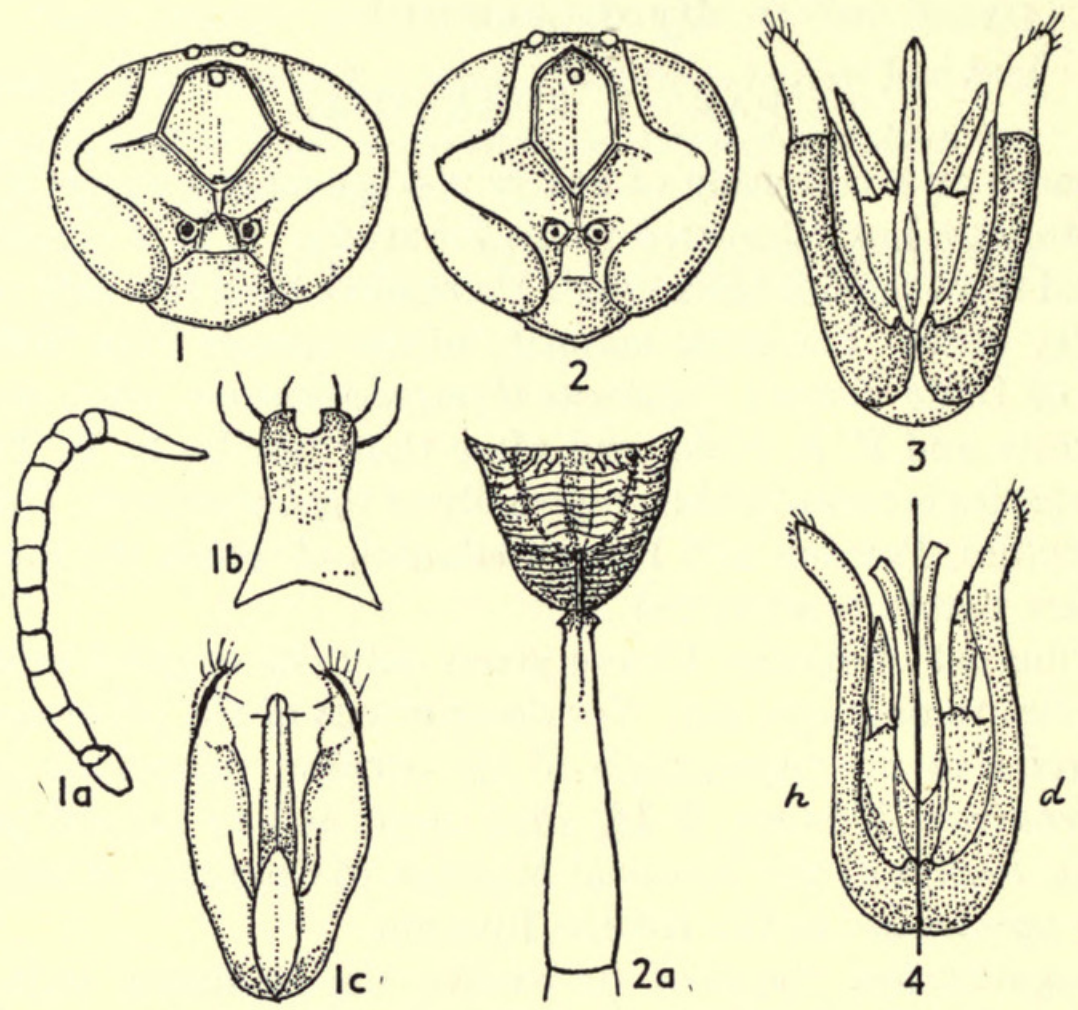

FIG. I. Trypoxylon viduum $\hat{\sigma}$, head, $\times$ I5 $_{5}$. FIG. Ia. Trypoxylon viduum $\hat{\delta}$, antenna, $\times \mathbf{I}_{5}$. Fig. Ib. Trypoxylon viduum ${ }^{\star}, 8$ th sternite, $\times 27$. FIG. Ic. Trypoxylon viduum $\widehat{0}$, genitalia, $\times 27$. FIG. 2. Trypoxylon acutangulum , head, $\times$ I5 $_{5}$. FIG. 2a. Trypoxylon acutangulum ㅇ, epinotum and petiole, $\times$ 5. FIg. 3. Philanthus ugandicus $\hat{\sigma}$, genitalia, $\times 2$ I. FIG. 4. Philanthus histrio $\hat{\sigma}$, genitalia, $h$; Philanthus histrio, race distinctus, $d, \times 24$.

puncturation is larger and deeper at the sides. Second joint of the flagellum twice as long as wide, as long as the third, the apical joint acute, four times longer than wide at the base and nearly as long as the four proceeding joints united. Interocular distance on the vertex equal to the length of the first three joints of the flagellum plus half of the fourth. Posterior ocelli as far from the eyes as from each other. Pronotum and mesonotum nitidulous, the former with sparse punctures and rounded shoulders, the mesonotum sparsely punctured in the middle but more closely at the sides, the punctures about as large as those on the facial shield. Mesopleura shining, a little more finely punctured than the mesonotum. (Scutellum and metanotum obscured by the pin.) The $\mathrm{U}$-shaped area of the epinotum obliquely rugose over the basal third, the median groove wide and transversely costate, the rest of the area finely rugose, the sides of the epinotal dorsum and the declivity very coarsely transversely rugose and with anastomoses. The sides of the epinotum shining, vertically and not closely striate. Petiole slender, fully six and a half times longer than wide 
across the node, and as long as the second, third, and half the fourth tergites united. The second tergite is as long as the third, and not quite twice as long as wide behind. Second abscissa of the radius twice as long as the first. The eighth sternite resembles that of T. abditum Arnold, but differs in having three stout bristles emitted from each arm; the genitalia are like those of $T$. cognatum Arnold but the outer paramera are narrower.

Jowaha, N. of Debra Sina, 6,00o ft., Ethiopia, I of. $^{\text {. }}$

This could be the of of $T$. latiscutatum Arnold, but I hesitate to ascribe it to that species in the absence of females from the same locality.

\section{Trypoxylon acutangulum sp. $\mathrm{n}$.}

(FIGs. 2, 2a)

ㅇ. $9 \mathrm{~mm}$. long. Black. Tarsi dark brown, the apical joint of the hind pair ochreous. Wings hyaline, the veins black, the costa brownish-yellow at the base. Clypeus and lower half of the face with silvery pubescence, the thorax with sparse whitish pubescence. Facial shield and ocular sinuses dull, closely and very finely punctured (30 diameters), the vertex in front of and between the ocelli less closely punctured and with a row of larger punctures behind the shield. Anterior margin of the clypeus convex. Facial shield entire, narrow, three-fourths longer than wide across the lateral angles, the apical angle acute. A faint trace of a carina is emitted from the angles into the ocular sinuses. Interocular distance on the vertex equal to the length of the first two joints of the flagellum plus two-thirds of the third joint. Posterior ocelli almost contiguous with the eyes. Second joint of the flagellum as long as the third. Shoulders of the pronotum rounded. Mesonotum and scutellum shining, very finely punctured, the interspaces fully twice as wide as the punctures on the sides of the mesonotum, wider on the disk. Mesopleura more finely punctured and more sparsely than the mesonotum. Median area of the epinotal dorsum U-shaped, one-fourth wider at the base than long, shallowly grooved down the middle, reticulate-rugose at the base, transversely and finely rugose elsewhere, the rugae extending over the lateral areas of the dorsum. Declivity transversely rugose and finely punctured, and with a deep median longitudinal impression. There is a deep pit at the brow of the declivity. Sides of the epinotum shining, finely transversely striate. Petiole four and a half times longer than wide behind, as long as the second tergite plus two-thirds of the third. Second abscissa of the radius two and a half times longer than the first.

Niamey, French West Africa, August I.944, I ㅇ.

Remotely related to $T$. kohli Arnold, but smaller, with a narrower facial shield and a shorter petiole.

Subfamily Philanthinae

Philanthus coarctatus Spinola

1838, Ann. Soc. Ent. Fr. 7: 486.

Ufdem, Ethiopia, August I944, I ô. 


\section{Philanthus rubidus Arnold}

P. abyssinicus Arnold, 1932, Occ. Pap. Rhod. Mus. 1: 7 .

P. rubidus Arnold, 1946, Occ. Pap. Nat. Mus. S. Rhod. 12: 82.

River Errer, near Harar, Ethiopia, May 1948, I ô.

\section{Philanthus ugandicus Magretti}

1908, Bull. Mus. Hist. Nat., Paris, 14: 188.

Adis Ababa, Dessie, and Zuquala (9,00o ft.), Ethiopia, 7 추․

Philanthus histrio distinctus subsp. n.

(FIG. $4 d$ )

P. histrio Fabricius, 1804, Syst. Piez.: 301.

o. I2 mm. long. Black, the occiput slightly rufescent. The pale markings on the head and abdomen are similar to those of histrio i. sp. but the colour is creamy white instead of yellow, the clypeus has a rectangular black macula in the middle of the anterior margin, and the maculae on the second tergite are larger and not triangular, but nearly round.

The thorax is entirely black. Fore legs brown, middle and hind femora black, their tibiae and tarsi brownish, the former with the apical third whitish on the outside, and also the first four tarsal joints. Puncturation on the vertex behind the ocelli larger and wider apart than in the type of the species; the puncturation of the mesonotum also a little coarser, otherwise the sculpture is like that of the type of the species. The second joint of the flagellum is thinner, being nearly four times longer than the third. The genitalia differ slightly, the apical third of the outer paramera being narrower and more acute at the apex. (Fig. $4 h$, genitalia of histrio i. sp.)

Debra Sina, Ethiopia, November I945.

\section{Philanthus loefflingi Dahlbom, var. meneliki Arnold} 1925, Ann. Transv. Mus. 11: 150.

Bishoftu; Ethiopia, June I948, I oै.

Philanthus dichrous dolosus Kohl, var. abyssinicus Arnold 1925, Ann. Transv. Mus. 11: 162.

Goré, Ethiopia, February I948, I ô, 2 우우.

In these specimens the thorax is entirely black, as are also the middle and hind legs.

\section{Philanthus fuscipennis consimilis Kohl}

1891, Ann. naturh. Hofmus. Wien, 6: 349.

Bishoftu and Jowaha, Ethiopia, $3 \widehat{\jmath} \widehat{s}$. These three are a slight variety in which the hind tibiae are yellow. In one of the specimens from Jowaha the scutellum and postscutellum are also yellow.

\section{Subfamily CERCERINAE}

In Plates 4 and 5 the male genitalia of the majority of the species described hereunder are illustrated. For figures of other species included in the Guichard collection 
and which are also found in the southern half of the continent the reader should refer to my paper on Cerceris published in the Journal of the Entomological Society of Southern Africa, 5, I942. For the sections into which I have separated the females, the chapter on the genus in my monograph of the African Sphecidae, in the Annals of the Transvaal Museum, 14, part 2, should be consulted. These sections are solely for the purpose of facilitating the identification of the species and are not natural, as can be seen by a comparison of the genitalia of the corresponding males. For example, the genitalia of species in which the females have such distinctive characters as a porrect clypeus lamina, sections B and C, or a median tubercle, section $\mathrm{E}$, can differ considerably.

I am unable to recognize the validity of the subgenus Apiraptrix Shestakov, which is based on the presence of a basal platform on the second sternite. In some species there is a more or less distinct median carina on that segment which is sometimes flattened cephalad. The basal platform appears to have arisen by a gradual reduction of the carina, but the platform is by no means always distinctly defined. In fact an examination of a fair proportion of the species shows that there is a gradation from a raised area with well-defined margins to one which is barely recognizable. In one case, $C$. varicincta Cameron, this variability is exhibited within the species.

\title{
Cerceris longiuscula sp. n.
}

\author{
(FIGS. 5, 5a; PL. 4, FIG. I)
}

๙. I4 mm. long. Black. Apical margin of the first tergite and all of the following tergite pale burnt umber, the second and third paler than the rest. Sternites $2-7$ dull yellow, stained with brown over their apical halves. Apical third of the fore and middle tibiae and all the tarsi, pale reddish-brown. The following parts are creamy white: clypeus excepting the black anterior third, sides of the face up to the level of the antennal sockets, lower half of the frontal triangle, a small round spot at the top of the temples, a small transverse spot on the pronotal shoulders, a triangular spot on the mesopleura below the tegulae, and a transverse spot on each side of the scutellum.

Wings pale fuscous. Clypeus dull, very finely rugulose, and with a few shallow punctures superimposed; the lateral sclerites with sparse, decumbent, and yellow pubescence. The rest of the head dull, with a microscopic and dense puncturation, on which is superimposed a larger and deeper one which becomes finer dorsad, the interspaces a little wider than the punctures. Between the ocellar area and the antennal sockets there are also a few longitudinal rugae. The frontal carina is high and acute. Thorax dull. Anterior face of the pronotum almost smooth, the dorsal face finely and very sparsely punctured. The puncturation of the mesonotum and scutellum a little larger and closer than that of the face, that of the mesopleura much larger and closer, reticulate punctate; the metapleura are costate except over the middle third. The epinotum, excepting the triangular area and the somewhat shining middle lower half of the declivity, has a puncturation about twice as large as that of the mesonotum, but less close; the triangular area is obliquely costate, eight costae on each side. Tergites microscopically reticulate and dull, with a very sparse, small, 
and shallow puncturation on the second to sixth tergites, the first tergite with a sparse and large one.

Pygidial area coarsely punctured, rectangular, twice as long as wide, the apical margin straight. Sternites shining, shallowly punctured, the sixth with a small tooth on each side near the apical margin. Median area of the clypeus long, about half as long again as wide, produced well beyond the lateral sclerites, shallowly grooved in the middle of the apical half, the apical margin feebly concave. Inner orbits feebly divergent below, the interocular distance across the clypeus very little greater than across the vertex. Posterior ocelli twice as far from the eyes as from each other; the interocular distance on the vertex equal to the length of the first four joints of the flagellum. The second joint is twice as long as wide at the apex and one-fourth longer than the third, the apical joint twice as long as wide at the base and obliquely truncate.

Dorsum of the pronotum not short, as long as the third joint of the flagellum. Mesonotum wide, four-fifths wider than long. First tergite nearly twice as wide behind as long, the second two-thirds longer than the first and three-fourths wider behind than long. Posterior tibiae with six serrations.

Kpeve, Gold Coast, June I942, I o.

Not related to any other African species known to me. The outer paramera of the genitalia are distinctive, being produced into an acute tooth on the inside not far from the apex.

\section{Cerceris pallida Arnold, var. lutulenta var. $n$.}

\section{C. pallida Arnold, 1935, Bull. Soc. Sci. Nat. Maroc, 15: 5.}

ㅇ. I $5 \mathrm{~mm}$. long. This is a variety in which the colour of the head and thorax is dull ochreous, the mesothorax pale ferruginous, with the margins of the mesopleura and the middle of the epinotal declivity blackish. The tergites are ochreous, the first four black at the extreme base and apex. Legs reddish-yellow.

Boghé, Mauritania, September I943, I ․

\section{Cerceris moggionis sp. $\mathrm{n}$.}

$$
\text { (FIgs. 6, 6a and 6b; PL. 4, FIG. 2) }
$$

6. I3 $\mathrm{mm}$. long. A streak on the upper half of the median area of the clypeus and the posterior margins of the lateral sclerites straw-yellow, the rest of the clypeus brown. Sides of the face, frontal triangle, and the frontal carina also pale yellow, the vertex reddish-brown at the sides, the rest of the head black. Antennae ferruginous, the last three joints black. Pronotum dark ferruginous, blackish in the middle and at the lower margins of the sides, the tegulae ferruginous, the rest of the thorax black. Abdomen pale ferruginous or yellowish-red, the apical half of the first tergite pale yellow, a median triangular area on the second sternite and the basal halves of the third to sixth sternites, blackish. Legs pale ferruginous. A small elongate spot on the outside of the apical half of the anterior femora, the apical two-thirds of the underside of the middle and hind femora, the upper side of the hind coxae and the upper side of the middle and hind tibiae, pale yellow. 
Wings pale fuscous, with a violaceous tint, darkest on the costal margin and radial cell. Head with a decumbent silvery pubescence, less dense on the vertex than elsewhere. Epinotum with exserted, fairly long and white pilosity. Abdomen with short, sparse, and yellowish pubescence. Clypeus dull and smooth, the rest of the head and the dorsum of the pronotum reticulate-punctate, the punctures about one-third as wide as the anterior ocellus. Anterior face of the pronotum shallowly punctured, the sides transversely rugose. Metapleura transversely costate above and below, the rest
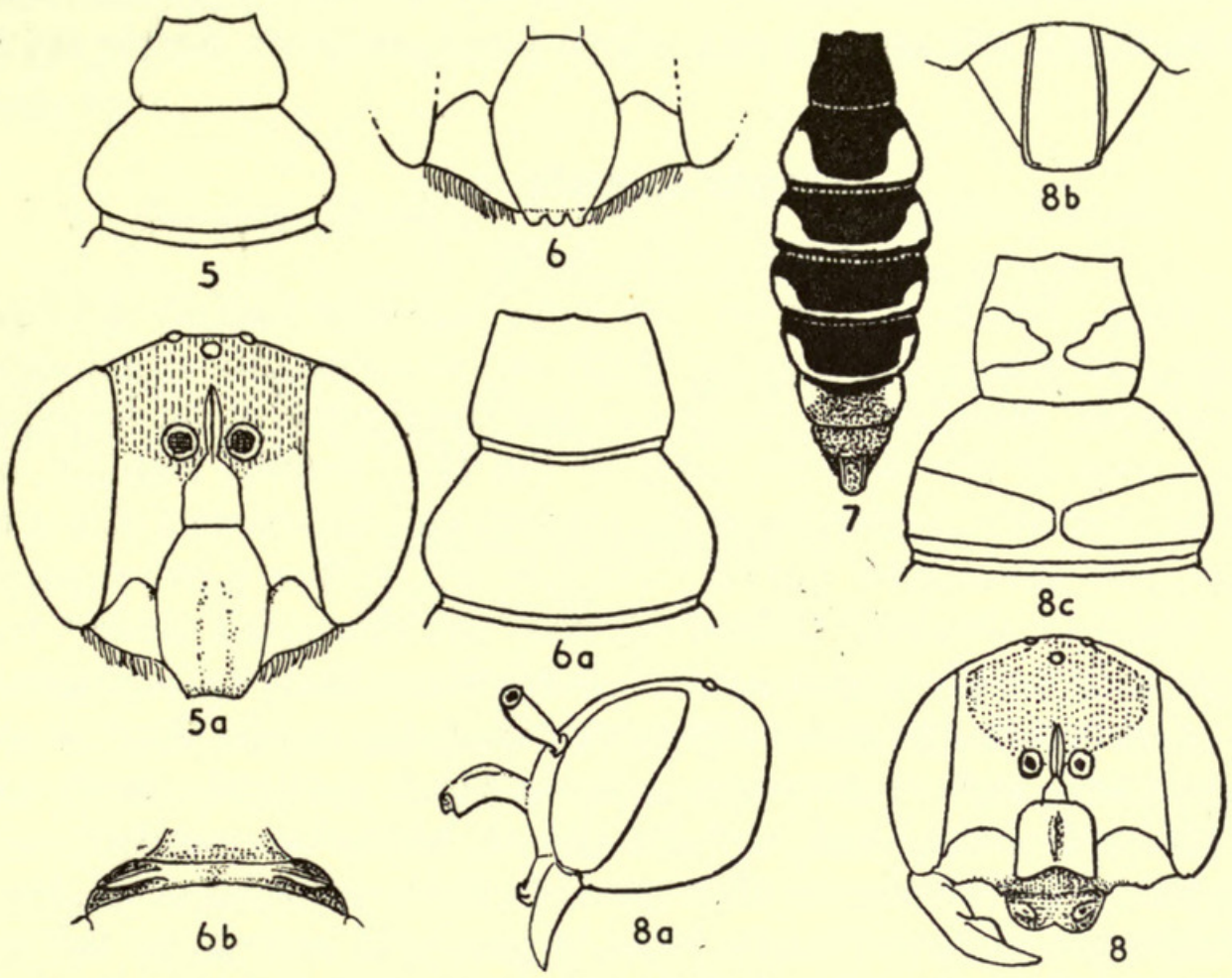

Fig. 5. Cerceris guichardi $\hat{\delta}$, first two tergites, $\times 6$. Fig. 5a. Cerceris guichardi $\hat{\delta}$, head, $\times$ Io. Fig. 6. Cerceris moggionis ${ }^{\star}$, clypeus, $\times$ Io. Fig. 6 a. Cerceris moggionis ${ }^{\star}$, first two tergites, $\times$ Io. Fig. 7. Cerceris insignita $\hat{\delta}$, abdomen, $\times 6$ (stippled parts ferruginous). FIG. 8. Cerceris flavonasuta +, head, $\times$ Io. FIG. $8 a$. Cerceris flavonasuta , first two tergites, $\times$ Io. Fig. $8 b$. Cerceris

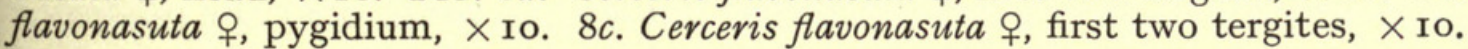

of the thorax strongly reticulate-punctate, the punctures on the mesothorax a little larger and deeper than those on the head. Median area of the epinotum with six large transverse costae. Tergites I-5 not quite dull, with fairly large punctures, the interspaces for the greater part twice as wide as the punctures, the sixth finely punctured and dull, the pygidial area nearly twice as long as wide, the lateral margins parallel over the basal half, convex outwardly on the apical half, the apical margin convex. Sternites I-6 shining, shallowly and sparsely punctured, the sixth with a yellow fimbria on its hind margin and a triangular tooth on each side. Median area of the clypeus oval, feebly convex, nearly half as long again as wide, the apical margin with three large and rounded teeth. Inner orbits parallel. Vertex wide, the interocular distance there equal to the length of the first five joints of the flagellum. Posterior ocelli twice as far from the eyes as from each other. Second joint of the flagellum a little more than twice as long as wide, two-fifths longer than the third, the apical joint half as long again as wide, transversely truncate at the apex. Shoulders ENTOM. 2. 3 
of the pronotum angular, raised to form a subcarinate tubercle. Mesopleura with a small tooth below. Scutellum depressed lengthwise in the middle. Epinotal dorsum short, about as long as the scutellum. First tergite three-eighths wider behind than long, second tergite seven-ninths wider than long. Hind tibiae with five serrations.

Moggio, Ethiopia, April 1948, I of.

Not related to any other Ethiopian species. The tuberculate pronotal shoulders and the shape of the outer paramera of the genitalia are distinctive. The outer paramera have on the inside, a little behind the middle of their length, a lamelliform fimbriated lobe, which can be seen only when those parts are widely splayed out.

\section{Cerceris insignita sp. $\mathrm{n}$.}

(FIG. 7 ; PL. 4, FIG. 3)

๙. II mm. long. Black. Antennae, occiput, posterior half of the temples, pronotum, tegulae, scutellum, metanotum, sixth and seventh abdominal segments, and the legs, ferruginous. Mandibles ferruginous, last three joints of the flagellum blackish above, median area of the clypeus, sides of the face, frontal triangle, and carina, yellowish-white ; the lateral sclerites of the clypeus pale brown and with a fine yellowish pubescence, the moustache brown. Tergites $2-5$ with a narrow pre-apical pale yellow band which is abruptly dilated laterad, the dilatation almost reaching the base, the sixth with a yellow spot on each side. Sternites fusco-ferruginous. Wings hyaline, the veins brown, the pterostigma ochreous, the apical third of the forewing pale fuscous. Clypeus and yellow areas of the face dull, shallowly, finely and sparsely punctured. The rest of the head, and the thorax, reticulate-punctate and dull, the punctures on the vertex about one-third as wide as the anterior ocelli, the punctures on the mesonotum and scutellum a little larger, and largest on the mesopleura. Triangular area of the epinotum slightly shining, closely and transversely rugose, the middle third of the epinotal declivity shining and almost smooth. Tergites I- 6 dull, sparsely punctured, the punctures as large as those on the vertex. Pygidial area shining, sparsely punctured, nearly parallel-sided but a little wider over the posterior half, the apical margin convex. Sternites smooth and shining, the sixth with a curved tooth on each side below which there is a bundle of ferruginous hairs; seventh sternite arcuately emarginate at the apex, the lateral margins raised or carinate.

Median area of the clypeus convex, suboval, half as long again as wide, the apical margin tridentate. Inner orbits parallel. Posterior ocelli twice as far from the eyes as from each other. Interocular distance on the vertex equal to the length of the first five joints of the flagellum. The second joint is twice as long as wide, one-fourth longer than the third, the apical joint truncate. Dorsum of the pronotum short, as long as the first joint of the flagellum, the shoulders subangular. First tergite as long as wide behind, the second two-thirds wider behind than long. Hind tibiae with five serrations.

Moggio, Ethiopia, April r948, I ot.

The colour pattern of the tergites is unlike that of any other Ethiopian species. Although so different in colour from C. moggionis, it is allied to that species, but the genitalia are different. The outer paramera are elongate triangular over the distal 
third and acute at the apex. Another specimen, also from Moggio, represents a variety, opulenta var. n., which differs from the type as follows:

๙ ${ }^{\star}$. I $\mathrm{mm}$. long. Occiput and temples black, the latter with a small ferruginous macula on top. The yellow areas on the tergites are more extensive, so much so that on the second tergite the black area is reduced to a transverse band at the base and a small triangular pre-apical macula, its base caudad. On the third tergite the black covers only the middle third of the segment, a little more on the fourth and fifth, but on the latter the black merges caudad into ferruginous. The first tergite is a little broader in proportion to its length, and the sculpture on the head and thorax is also a little shallower.

\section{Cerceris rufiscutis Cameron, var. decolorata Arnold}

C. rufiscutis Cameron, I9Io, Sjöstedt's Kilimandjaro-Meru Exped. 8: 278.

Arnold, 1931, Ann. Transv. Mus. 14: 182.

Haramaia, April I948, I 우 I đ*; Lake Bishoftu, Ethiopia, August I946, I 9 ; Moggio, April I945, I ơ; Lekempti, Ethiopia, June I946, I đ.

\section{Cerceris flavonasuta sp. $\mathrm{n}$.}

(FIGs. 8, 8a-c; PL. 4, FIG. 9)

ㅇ. I2.5 $\mathrm{mm}$. long. Head ferruginous, with a large macula extending from the antennal sockets to a little distance behind the ocellar area, and the anterior half of the temples black. Lamina of the clypeus pale yellow, its apical margin blackish; the median area below it black. Frontal carina pale yellow, mandibles fusco-ferruginous, antennae ferruginous, the fifth and following joints of the flagellum fuscous above. Thorax black, the metanotum pale yellow. Tergites I-4 and the basal half of the fifth black, the first to third with pre-apical yellow bands, narrowly interrupted in the middle and moderately dilated laterad, the fourth with a very thin pre-apical yellow band; the sternites I-4 black, the second and third with a large yellow macula on each side, the fifth and the whole of the apical segment ferruginous. Antennae, apices of the femora, tibiae, and tarsi ferruginous. The hind coxae with a pyriform yellow macula on the upper side. Wings hyaline, tinged with dull yellow, the pterostigma ochreous, the veins brown, the tegulae ferruginous.

Labrum wider than long, with a large tubercle on each side. Median area of the clypeus below the lamina smooth and shining. The lamina is free to its base, as long as wide, convex transversely and strongly so lengthwise, a little wider in front than behind, shining, sparsely punctured and broadly carinate lengthwise in the middle, the apical margin shallowly excised. Lateral sclerites of the clypeus shining and sparsely punctured.

Head dull and reticulate-punctate, finely on the face, more strongly on the vertex, with the meshes emphasized longitudinally, and more finely and closely on the occiput and upper part of the temples; the underside of the head is longitudinally rugose and fairly strongly punctured in between.

Thorax dull, pronotum closely and finely punctured, mesonotum and scutellum longitudinally and finely rugose, punctate, the punctures on the middle part of the 
mesonotum largest and not so large as on the upper part of the face. Metanotum finely and sparsely punctured.

Mesopleura and epinotum closely rugulose-punctulate, with a shallow larger puncturation superimposed. Triangular area of the epinotum closely and obliquely rugulose, finely punctured between the rugae. First tergite shining, with sparse and large punctures. The second to fifth closely and finely punctured over the basal half, more sparsely with larger punctures apically.

Pygidial area widened towards the straight apical margin, and half as long again as wide there. Sternites shining, shallowly and sparsely punctured, the sixth deeply and narrowly excised. Mandibles with a broad rounded tooth at the middle of the inner margin. Interocular distance on the vertex equal to the length of the first six joints of the flagellum, the second joint five-eighths longer than the third. Ocelli half as far again from the eyes as from each other. Temples wide, at their widest clearly wider than the eyes. Pronotal collar short, the shoulders rounded. Mesopleura with a feeble denticle below. First tergite as long as wide, the second three-fourths wider than long. Posterior tibiae with seven spiniferous serrations.

o. $9.5 \mathrm{~mm}$. long. Clypeus, frontal triangle and carina and lower two-thirds of the face, excepting a black streak extending from the antennal sockets to the clypeus, pale chrome yellow; the mandibles ochreous, black at the apex, the rest of the head black.

Pronotal collar with a transverse yellow band, narrowly interrupted in the middle. Apical margin of the fifth abdominal segment, and the whole of the sixth and seventh ferruginous. Posterior coxae and trochanters pale yellow on the underside. Eighth to eleventh joints of the flagellum infuscated on the upperside. Otherwise coloured like the 우.

The sculpture is everywhere a good deal more coarse than in the $q$. Yellow areas of the face and the clypeus dull, shallowly and sparsely punctured, the interspaces about three times wider than the punctures. Thorax dull, the abdomen nearly so. Pronotal collar sparsely and shallowly punctured. Mesonotum and scutellum clearly longitudinally and finely rugose with a shallow and not close puncturation in between the rugae. Mesopleura coarsely reticulate-punctate, the punctures about half as wide as one of the posterior ocelli. Triangular area of the epinotum closely, obliquely, and finely rugose, grooved down the middle; the rest of the epinotum with a large and deep puncturation. The abdominal segments have a microscopic and close fundamental puncturation on which is superimposed a larger one, the punctures as large as those on the epinotum, but more widely spaced, the interspaces being for the greater part two and a half times wider than the punctures. Pygidial area slightly widened towards the transverse apex, half as long again as wide, the sides slightly convex. Median area of the clypeus slightly flattened, a little longer than wide, the apex tridentate. Interocular distance on the vertex equal to the length of the first six joints of the flagellum. Apical joint of the flagellum curved, twice as long as wide, the apex transversely truncate. First tergite nearly one-fourth longer than wide. Posterior tibiae with six serrations.

Aselle, Ethiopia, July I947, I 우

This species belongs to the small section B in my key to the species (I93I, Ann. 
Transv. Mus. 14: I37), which also includes C. andersoni Turner. It differs from that species and the other four species by the shape of the clypeal lamina and pygidial area, and from proteles Brauns, bicolor Smith (Pl. 4, fig. 4), and pictiventris Gerstaecker by the colour of the abdomen.

\section{Cerceris fulviventris Guérin}

(PL. 4, FIG. 4)

1844, Icon. vègne anim. 7: 444 .

C. bicolor Smith, 1856, Cat. Hymen. B.M.: 447.

Guiglia, 1948, Ann. Mus. Stor. Nat. Genova, 63: 187.

Kaolack, August I943, I o ; Kaffrine, August I943, I o and I 9 .

Guiglia's redescription of fulviventris Guérin, based on the type, appears to me sufficient evidence that bicolor Smith should sink in synonymy. The colour of the ot in regard to the yellow markings is variable. In the $\sigma^{t}$ from Kaolack all the tergites have a short yellow streak on each side at the hind margin. It should also be noted

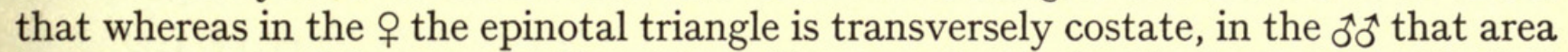
is coarsely reticulate-rugose. The ${ }^{*}$ is easily recognizable by the large semi-elliptical lobe, directed ventrad, on the inner inferior margin of the outer paramera of the genitalia.

19г3, Rev. zool. afr. 3: 207.

\section{Cerceris severini Kohl}

Brauns, 1926, Ann. Transv. Mus. 11: 289.

Diaforabe, French Sudan, August I944, I ô, I 9 ; Abbai Gorge, Ethiopia, October I945, I + ; Niamey, Niger Colony, August I944, I o ; Tillembeya, River Niger, French Sudan, September I944, 4 бేశ. The specimen from Abbai Gorge has the first tergite, excepting the apical margin, black, and third to fifth tergite infuscated in the middle.

It should be observed that there is an error in Dr. Brauns's translation of the original description, which runs 'The fourth (i.e. third) abscissa of the radius is one and a half times longer than the first three (i.e. two) united, which are very short.' Kohl says: 'Der Abschnitt der Radialader, welcher die 3 Cubitalzelle vorne begrenzt, ist sehr viel kürzer als das folgende Stück, welches mehr als $I_{2}^{\frac{1}{2}}$ Mal so lang als wie jenes ist.'

\section{Cerceris zavattarii Guiglia}

(PL. 4, FIG. 5)

1939, R. Accad. Ital. Miss. biol. Borana, 3 (2): 58.

I ascribe to this species, known to me only from the description, a specimen to which I refrain from giving a varietal name, since it differs only in minor details and greater size from one of the paratypes mentioned by Guiglia.

o. I4 mm. long. The dark areas of the head and thorax are black, without any ferruginous parts. The vertex has two small yellow spots behind the ocelli. The median maculae on the tergites are shorter, not reaching the apical margin, and also more semicircular, that on the first black and on the following fusco-ferruginous. The interocular distance on the vertex is equal to a little more than the length of the 
first four joints of the flagellum. The second joint of the flagellum is fairly slender, or two and three-fifths longer than wide at the apex, the apical joint is short and obliquely truncate. The dense exserted and yellow pilosity on the sternites, including even the eighth, is a distinctive character.

Bishoftu, 7,000 ft., Ethiopia, May I948.

This species bears a strong resemblance to $C$. nugax Arnold and like it has the sternites densely pilose. It can be distinguished, however, by the very different sculpture of the epinotal triangle, by the more slender antennae, the narrower first tergite, and the shape of the outer paramera of the genitalia, which are more acute at the apex and strongly dentate on the inner margin.

\section{Cerceris rhodesiae Brauns}

I929, Ann. Transv. Mus. 11: 330.

$$
\text { (PL. 4, FIG. 6) }
$$

\section{Arnold, 1942, J. Ent. Soc. S. Afr. 5: 20.}

I reduced this species to the rank of a subspecies of $C$. monocera Kohl, but on reexamination, and a more careful comparison of the genitalia, find that the latter organs are not identical as I believed. Since the stipites or outer paramera are in most cases curved, it is necessary in comparing them to arrange them in exactly the same plane. As a result, it can be seen that though the genitalia are very similar, in those of rhodesiae the dilatation or lobe on the inner margin of the outer paramera is less abrupt, and the distal portion beyond it is longer and rounder at the apex. Also the differences in the puncturation and in the colour pattern are too great to be considered merely subspecific. Furthermore, another character which I overlooked is to be seen in the radial cell. In rhodesiae it is truncate at the apex, whereas in monocera the apex is bluntly angular and ends on the costal margin. For these reasons rhodesiae must be restored to specific rank. A specimen in this collection represents a subspecies, rhodesiae haramaiae subsp. nov.

o. II $\mathrm{mm}$. long. In colour this differs from the species in having pale yellow bands, dilated laterad, on the second to sixth tergites, an elongate macula of the same colour on each side of the epinotal declivity and the scutellum entirely black. The upper sides of the femora are dark brown, almost black on the hind pair. The dorsum of the thorax is moderately shining, the mesonotum more strongly rugose lengthwise, and the punctures between the rugae deeper. The puncturation of the epinotum is larger and deeper and less close, the interspaces smooth and fully as wide as the punctures, whereas in rhodesiae i. sp. the interspaces form raised meshes.

The median area of the clypeus is shorter and does not project so far beyond the lateral sclerites, it is one-fourth longer than wide, in rhodesiae very nearly one-half longer than wide. The ocelli are one and three-quarter times farther from the eyes than from each other, in rhodesiae one and a half. The first tergite is wider, or as wide as long, and in rhodesiae one-fourth longer than wide. The genitalia barely differ, the outer paramera being a little less widely dilated anteriorly and slightly rounded at the apex.

Haramaia, Ethiopia, May I948, I ơ. 


\title{
Cerceris campsomeroides sp. n.
}

\author{
(PL. 4, FIG. 7)
}

§. I4 mm. long. Black. Clypeus, excepting a wide anterior margin, sides of face, frontal triangle and carina, wide apical bands moderately dilated laterad on the second, third and fourth tergites and an apical band covering only the middle third on the fifth tergite, chrome yellow. Fore and middle femora black, their apical fourth, like the tibiae and tarsi dull yellow, the hind legs also of that colour, but the femora more or less stained reddish on the apical half. Apical joint of the flagellum and ochreous below. Wing hyaline, the veins reddish ochreous, the pterostigma pale yellow, the apical margin of both wings faintly fuscous.

Head and thorax with a long, erect, yellowish-grey pilosity, the abdomen with a shorter, oblique and sparser one, on the sternites somewhat denser on the apical margins. Yellow area on the head dull, longitudinally rugulose and finely and fairly closely punctured. The upper part of the face, excepting a small smooth area below the anterior ocellus, closely punctured and rugulose, the vertex and upper part of the temples less closely, with larger punctures which are about one-third as wide as one of the posterior ocelli, the interspaces a little wider than the punctures. Lower half of the temples strigose lenghtwise and closely punctured, the punctures smaller than on the vertex. Sides of the pronotum coarsely wrinkled, the mesopleura obliquely costate. The rest of the thorax strongly punctured, the largest punctures, on the scutellum and metanotum, are half as wide as one of the posterior ocelli, the interspaces wider than the punctures. Those on the pro- and mesonotum slightly smaller, and a little closer, on the epinotum equally large but closer, or almost reticulatepunctate. The triangular area on epinotal dorsum is dull, obliquely rugose and punctured, its lateral margins not impressed and therefore rather indistinct. First tergite with a puncturation like that of the epinotum, the second to fifth more strongly punctured on the apical than on the basal half, the interspaces a little wider than the punctures; the sixth and seventh tergites sparsely and coarsely punctured, the pygidial area a little narrower at the base than at the apex and fully twice as long as wide at the base, the apical margin straight. Tumid areas of the sternites with a shallow and fairly large puncturation. The whole body fairly dull. Median area of the clypeus fairly flat, one-seventh longer than wide, the apical margin strongly tridentate. Temples a little wider than the eyes. Posterior ocelli very little farther from the eyes than from each other, the interocular distance on the vertex equal to the length of the first five joints of the flagellum. The apical joint of the flagellum curved, excavated below, the two preceding joints also concave below and feebly carinate lengthwise. Dorsum of the pronotum sloping cephalad, as long in the middle as the third joint of the flagellum, the shoulders rounded. First tergite one-fourth wider behind than long, the second a little shorter than the first and fully twice as wide behind as long. Hind tibiae with seven spiniferous serrations. Second abscissa of the radius twothirds longer than the first.

Accra, Gold Coast, I94I, I of.

Not closely related to any other Ethiopian species. In the colour and narrow 
abdomen this insect has a superficial resemblance to the males of some species of the Scoliid genus Campsomeris, e.g. C. clotho Saussure.

\section{C. iniqua Kohl}

1894, Ann. naturh. Hofmus. Wien, 9: 288.

Lekempti, 6,500 ft., Ethiopia, May I946, I ơ.

Cerceris nobilitata walegae subsp. $\mathrm{n}$.

C. nobilitata Cameron, 1905, Trans. S. Afr. Phil. Soc. 15: 216.

ㅇ. I0.5 $\mathrm{mm}$. long. Larger than nobilitata, and differing from that as follows: Dorsum of the pronotum raised on each side into a transverse pale yellow torus,
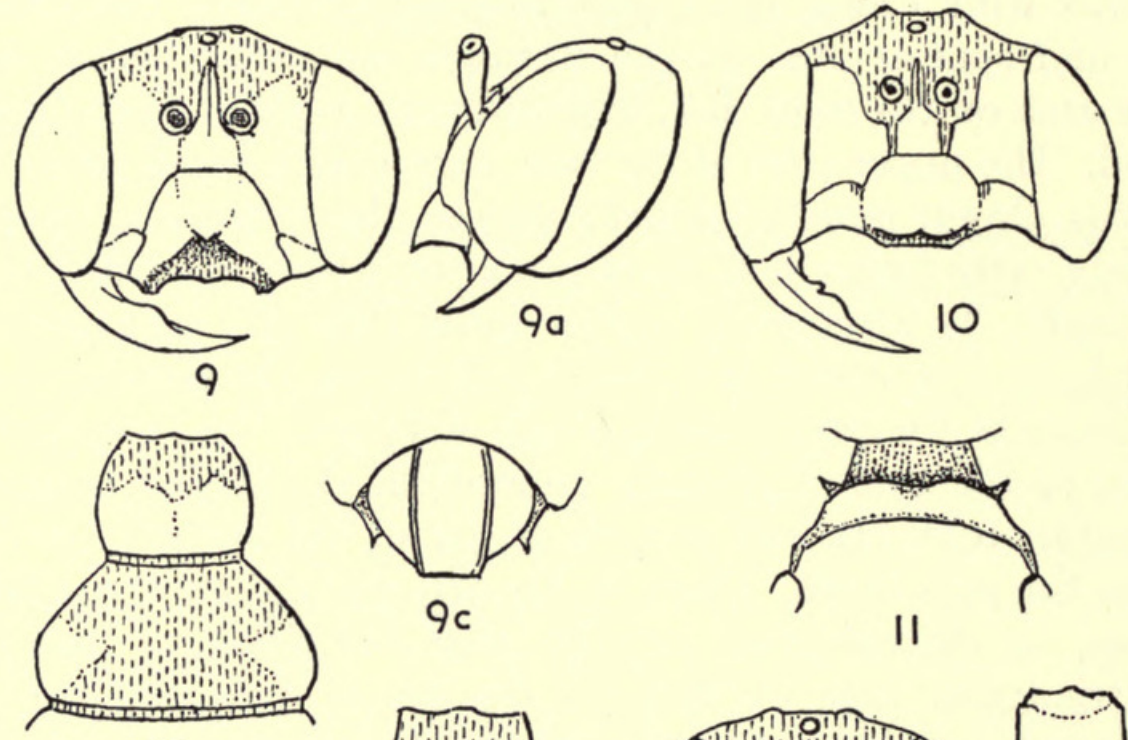

II

$9 b$

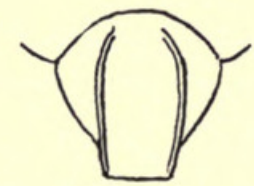

$1 \mathrm{Ob}$
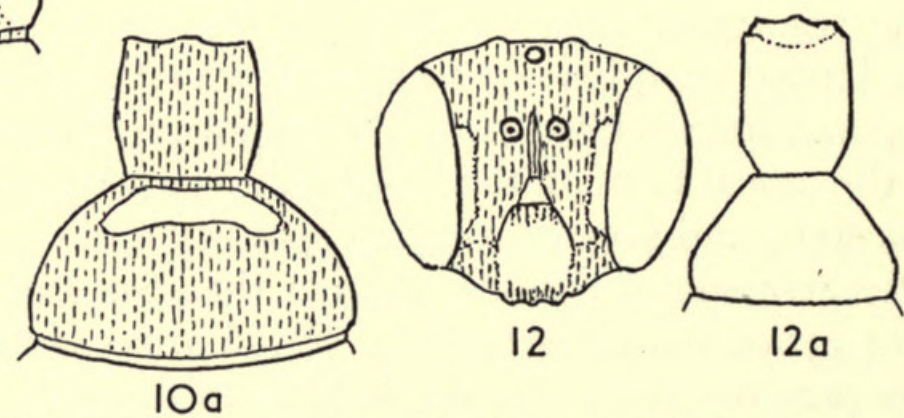

Figs. 9 and $9 a$. Cerceris facet $a$ 우, head, $\times 12$. Fig. $9 b$. Cerceris faceta, first two tergites, $\times 12$. FIg. 9c. Cerceris faceta, pygidium, $\times 12$. FIg. Io. Cerceris electra , head, $\times$ I2. FIg. Ioa. Cerceris electra, first two tergites, $\times$ I2. FIg. II. Cerceris maia ${ }^{*}$, pronotum, $\times$ I2. FIG. I2. Cerceris alcyone $\widehat{0}$, head, $\times \mathbf{I} 2$. FIG. I2a. Cerceris alcyone, first two tergites, $\times \mathbf{I} 2$.

similar to that in $C$. osiris Arnold but larger. Metanotum pale yellow, hind margin of mesopleura, the epinotum excepting the middle, and the first tergite and sternite and the second sternite, castaneous red. Second tergite black, the macula at the base yellow, not interrupted in the middle and larger. The apical band on the third tergite and the apical macula on the fifth pale ochreous, instead of yellowish-white, and larger. The puncturation of the abdomen is closer, the interspaces on the second to fifth tergites being, for the greater part, narrower than the punctures (wider in the type of the species). The first tergite is widest behind the middle, instead of at the 
middle. The fore and middle femora are stained with black above, and the hind femora are castaneous red. Otherwise like the type of the species.

Gambeila, $700 \mathrm{ft}$., in the territory of the Walega and Nuer tribes, Ethiopia, February, I948, I ㅇ․

The yellowish parts of the head have been discoloured to reddish-yellow by cyanide fumes.

In the presence of the tori on the pronotal dorsum this race resembles $C$. osiris, which is closely allied to nobilitata.

\section{Cerceris faceta sp. $n$. \\ (FIGS. 9, 9a-c; PL. 4, FIG. 8)}

․ $9 \mathrm{~mm}$. long. Black. The following parts are bright lemon-yellow: mandibles excepting the apex, clypeus excepting the median apical margin and the underside of the median cone, frontal carina, scapes, sides of the face, a small spot behind each eye, pronotal collar, tegulae, a round macula on the mesopleura below the wing-base, a round macula on each side of the scutellum, the metanotum, an ovoid macula on the sides of the epinotum, a band on the first tergite covering nearly the apical half, a transverse apical macula on each side of the second tergite, a wide apical band on the third, slightly dilated laterad, a much narrower one on the fourth, the apical half of the fifth, more or less triangular lateral maculae on the second, third, and fourth sternites, and the legs. The hind femora on the upper side, and the hind tibiae on the underside, streaked with black. The flagellum brownish-yellow above, ochreous below, the first two joints blackish. Wings hyaline, the forewing faintly fuscous at the apex, the pterostigma reddish-brown. Clypeus, face, and temples and mesopleura with fairly dense, whitish decumbent pubescence, elsewhere the pubescence is scanty. Yellow areas of the clypeus and face dull, not very closely punctured. Metanotum finely and sparsely punctured, metapleura obliquely rugose. Triangular area of the epinotum smooth and shining, grooved down the middle. The rest of the body is deeply and closely punctured. Second to fourth tergites are reticulate-punctate with punctures half as wide as one of the posterior ocelli, a little smaller but less close on the thorax and fifth tergite, smallest on the face and vertex which are reticulatepunctate. Pygidial area nearly twice as long as wide, the sides feebly convex, the apical margin straight, dull, coarsely punctured except over the apical third, which is rugulose. Sternites sparsely and coarsely punctured on the tumid areas. Mandibles with a low and wide tooth on the inner margin. Median area of the clypeus inflected in the anterior third, its anterior margin with a triangular tooth on each side; the basal two-thirds of the median area raised ventrad and ending in a short acute cone. Inner orbits feebly divergent above and below. Posterior ocelli half as far again from the eyes as from each other. Vertex wide, the interocular distance there equal to the length of the first seven joints of the flagellum. Pronotal dorsum convex transversely and lengthwise, in the middle as long as the second joint of the flagellum.

First tergite a little wider behind than long, the second as long as the first and twice as wide as long. Fifth sternite with an acute tooth on each side near the apical margin. Posterior tibiae with five spiniferous serrations.

ENTOM. 2. 3 
o. $7.5 \mathrm{~mm}$. long. Apical half of the sixth tergite yellow, the second to fifth sternites with small yellow maculae on each side; hind femora and tibiae yellowish-brown on the upper side; otherwise the colour is like that of the ?. Puncturation also as in the ㅇ.

Median area of the clypeus hexagonal, a little longer than wide, the apical margin tridentate. Apical joint of the flagellum two-fifths longer than wide, not emarginate on the inside, very little attenuated towards the rounded apex. The anterior inferior angles of the pronotum subdentate. Epimeron of the mesopleura swollen, clearly visible from the dorsal aspect. First tergite as long as wide, widest in the middle. Otherwise like the 우.

Fatick, Senegal, August I943, I o, I o

Related to $C$. rhodesiae Brauns, from which it differs by the smaller size, the smooth triangular area of the epinotum, the puncturation, and in the $\sigma^{t}$ also in the apical joint of the flagellum.

\section{Cerceris nugax Arnold}

I931, Ann. Transv. Mus. 14: I76.

(PL. 5, FIG. I7)

Tillembeya, River Niger, French Sudan, August I944, 2 đ̋స.

Fatick and Kaolack, Senegal, August I943, 3 రై

The specimens from Senegal differ from the type form in having the median triangular black area of the tergites wider.

A re-examination of the paratype from Dahalak (Dahleck) Island, Red Sea, indicates that it should be considered a distinct race, not only on account of its larger size, but also on account of the sculpture of the epinotal triangle and the shape of the outer paramera of the genitalia. The epinotal triangle is not arcuately and transversely costate all over as in the type and in the West African specimens listed above, but is obliquely costate, having about twelve costae divergent caudad from the base and four or five arcuate costae in the apical angle. The outer paramera are much blunter at the apex.

This race may be known as insularis (P1. 5, fig. I6).

\section{Cerceris yungvei Cameron}

(PL. 5, FIG. I8)

I9го, Sjöstedts Kilimandjaro-Meru Exped. 8: 273.

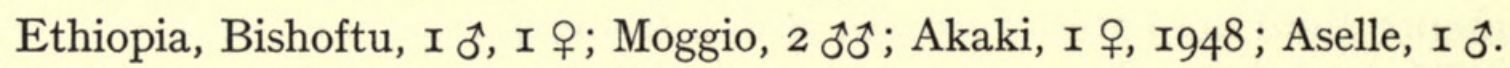

\section{Cerceris mazimba Brauns}

1926, Ann. Trans. Mus. 11: 295.

Arnold, 1942, J. Ent. Soc. S. Afr. 5: 9.

Tillembeya, River Niger, French Sudan, August I944, I 9,3 s.

In the $\delta, 9 \mathrm{~mm}$. long, the yellow markings on the abdomen are larger than in the type, but the genitalia do not differ. 


\section{Cerceris spinicaudata Cameron}

1905, Transv. S. Afr. Phil. Soc. 15: 2r6.

Accra, Gold Coast, 2 우우, August I94I ; Labadi, Gold Coast, I 0 , March ; Kaffrine, Senegal, I ô. August I943; Moggio, Ethiopia, I ô, June, I946

\section{Cerceris electra sp. n.}

(Figs. Io, Io $a$ and $b$ )

ㅇ. $8.5 \mathrm{~mm}$. long. Black. The following parts are yellowish-white: mandibles excepting the black apex, clypeus excepting the black anterior margin of the median area, sides of the face, frontal triangle and carina, upper side of the scapes, the outer thirds of the pronotal collar, the outer half of the tegulae, the metanotum, a broad transverse macula at the base of the second tergite, transverse apical bands on the third and fifth tergites, that of the third dilated laterad, and a large triangular macula on each side of the third sternite. Flagellum dark brown above, ochreous below. Fore and middle femora black above and at the base below, the underside yellowish-white, the hind femora with a spot of the same colour on the underside at the apex, the tibiae and tarsi pale yellow, the hind tibiae brownish above, the tarsal joints pale fuscous apically. Wings hyaline, the apex of the forewing fuscous, the pterostigma and veins brown. Clypeus and whitish areas of the face with a white and decumbent pubescence, the thorax and abdomen with sparse, short, and grey pubescence.

Clypeus and pale areas of the face dull, shallowly, finely and sparsely punctured, the rest of the head with punctures about one-third as wide as the anterior ocellus, the interspaces hardly wider than the punctures, except on the temples where they are a little wider.

Mesopleura coarsely reticulate-punctate and dull, the metapleura transversely striato-rugose, the triangular area of the epinotum shining, impunctate, and grooved down the middle. The rest of the thorax and the first five tergites moderately shining and with a strong puncturation. The punctures are about half as wide as the anterior ocellus, separated on the mesonotum and scutellum by interspaces wider than the punctures, and as wide on the tergites. Mesonotum impunctate. Tumid areas of the sternites less closely and more shallowly punctured than the tergites. The ventral margins of the first tergite are raised into a tubercle caudad, and the second sternite is feebly carinate lengthwise over the basal half. Pygidial area barrel-shaped, reticulate-rugose, nearly half as long again as wide, the apical margin straight. Mandibles with two small teeth on the inner margin. Median area of the clypeus fairly flat, a little wider than long, the anterior margin slightly inflected, the preapical margin forms two very short, wide, and convex lobes extending as far as the apical margin. Posterior ocelli a little farther from the eyes than from each other. Interocular distance on the vertex equal to the length of the first six joints of the flagellum plus half of the seventh. Second joint of the flagellum twice as long as wide. Anterior coxae produced outwardly in front, but not so much as in C. placida Arnold. First tergite about as long as wide, the sides feebly convex. Posterior tibiae with six spiniferous serrations. 
Labadi, Gold Coast, March I94I, I ㅇ.

Allied to $C$. placida from which it differs by the colour of the scutellum and tergites, the sparser puncturation of the thorax, the lamina of the pre-apical margin of the clypeus, and the narrower first tergite.

\section{Cerceris maia sp. n.}

(FIG. II ; PL. 5, FIG. IO)

๙. $8 \mathrm{~mm}$. long. Black. The following parts are pale yellow: clypeus excepting the black anterior margin, lower half of the face, a spot on the tegulae, apical bands on the second, third, fourth, and fifth tergites, that of the second dilated laterad, lateral maculae on the second to fourth sternites. The apical margin of the sternites, excepting the first, testaceous. Scapes yellow below, the flagellum ferruginous, paler below than above, the last four joints fusco-ferruginous above. Tarsi of the fore and middle legs reddish-yellow, the basal joint pale yellow except at the apex, the tibiae and trochanters ferruginous, darker above, the tibiae with a narrow reddish streak below. Trochanters and basal half of the hind femora pale yellow, the apical half black, the hind tibiae fusco-ferruginous, with a dorsal yellowish-white streak on the apical half, the hind tarsi reddish-yellow.

Wings smoky hyaline, the forewing beyond the cells and including the radial cell, pale fuscous, the pterostigma and veins dark brown. Head, dorsum of the thorax, first tergite, and sternites with a sparse, erect, and whitish pubescence. Clypeus and yellow areas of the face shining, strongly and closely punctured. Metapleura transversely costate, triangular area of the epinotum shining and smooth, feebly grooved down the middle; the rest of the body, excepting the basal halves of the sternites, coarsely reticulate-punctate, the punctures half as wide as the anterior ocellus, except on the head where they are a little smaller. Median area of the clypeus a trifle longer than wide, the anterior margin tridentate. Interocular distance on the vertex equal to the length of the first five joints of the flagellum plus two-thirds of the sixth. Posterior ocelli nearly half as far again from the eyes as from each other. Second joint of the flagellum one and a half times longer than wide, the apical third nearly twice as long as wide at the base, moderately curved and obliquely truncate. Anteroventral corners of the pronotum produced into acute triangular teeth, which are clearly visible when the insect is viewed from above.

Pronotal collar in the middle as long as the second joint of the flagellum. First tergite widened caudad, the sides convex, one-sixth wider behind than long, and as long as the second. Pygidial area half as long again as wide, the sides feebly convex, the apex rectilinear. Posterior tibiae with five serrations. Anterior coxae conically produced outwards, as in $C$. placita Arnold.

Moggio, Ethiopia, April I948, I ô.

Not related to any other Ethiopian species, and easily distinguished by the teeth of the pronotum.

Not to be confused with $C$. inconspicua Arnold, in which it is the prosternum which is dentate on each side. 
Cerceris alcyone sp. $n$.

(FIGS. I2, I2 $a$; PL. 5, FIG. II)

o. $8 \mathrm{~mm}$. long. Black. The following parts chrome yellow: the median area of the clypeus excepting the apical margin and extreme base, a narrow streak on each side of the face margining the eyes, frontal triangle and carina, an apical band slightly dilated laterad on the third tergite and on the third sternite, a very thin apical line on the fifth tergite (a brown one on the sixth), the apical half below of the hind coxae, and the hind trochanters. Mandibles ferruginous, black at the base and apex. Antennae dark brown, the first seven joints of the flagellum ferruginous below. Tegulae ferruginous. Fore legs pale ferruginous, the femora darker above. Middle femora and tibiae brownish above, red below. The tarsi brown excepting the basal joint, which is yellow. Hind legs brownish-red. Wings hyaline, the radial cell and anterior margin beyond it dark brown. Sternites nitidulous, the rest of the body dull. Clypeus and face not closely punctured, the interspaces about twice as wide as the punctures. Vertex and temples reticulate-punctate, the punctures one-fourth as wide as the anterior ocellus. Posterior margin of the sides of the pronotum transversely costate, the metapleura finely and transversely rugose, the triangular area of the epinotum transversely and arcuately rugose and grooved down the middle; the rest of the thorax coarsely reticulate-punctate, the punctures half as wide as the anterior ocellus. The puncturation of the tergites is as large as that of the thorax, but not quite so close, the interspaces being about half as wide as the punctures. The punctures on the tumid areas of the sternites are a little smaller than on the tergites. Median area of the clypeus feebly convex, one-third longer than wide, the apical margin distinctly tridentate. Interocular distance on the vertex equal to the length of the first seven joints of the flagellum. The second joint is twice as long as wide, and the apical two-fifths longer than wide at the base, and subconical. Posterior ocelli slightly farther from the eyes than from each other. First tergite onefourth longer than wide, narrower at the apex than at the base. Pygidial area about half as long again as wide, the apex transverse, the lateral margins feebly convex. Posterior tibiae with five serrations.

Moggio, Ethiopia, April I948, I ô.

This species resembles $C$. macalanga Brauns in the colour of the face and clypeus, but is not related. It is more closely related to C. spinicaudata Cameron, from which it differs by the colour pattern, closer puncturation, the rugose triangular area of the epinotum and the genitalia.

\section{Cerceris merope sp. $\mathrm{n}$.}

(FIgs. I3, I3 $a$, and I3 $b$; PL. 5, FIG. I2)

ㅇ. $8.5 \mathrm{~mm}$. long. Black. The following parts pale yellow: mandibles excepting the apex, clypeus excepting a narrow apical black margin, sides of the face, more narrowly above than below, upper side of the scapes, the outer thirds of the pronotal collar, the tegulae, metanotum, a transverse basal macula on the second tergite, an apical band very narrow mesad but reaching the base laterad on the third tergite, the tumid half of the third sternite, and an apical band on the fifth tergite dilated laterad, 
the fore and middle tibiae and underside of the femora, the posterior tibiae excepting an apical infuscation on the underside, the fore metatarsus, and the middle hind metatarsi excepting the extreme apex. The rest of the tarsal joints ochreous on the fore and middle legs, blackish on the hind legs.

Clypeus and yellow areas of the face shallowly and not very closely punctured. Vertex reticulate-punctate, the punctures one-third as wide as one of the ocelli;

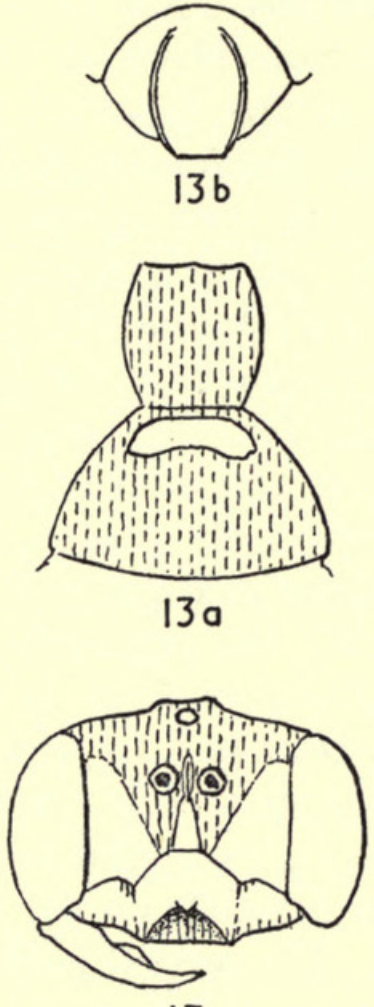

13
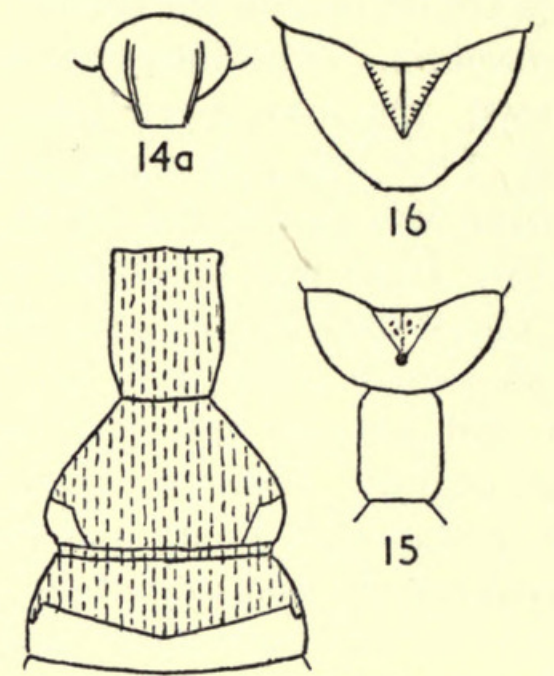

14

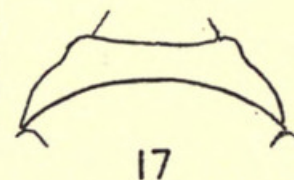

17

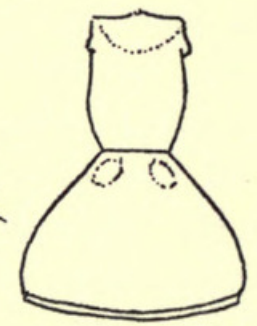

$17 a$

FIG. I3. Cerceris merope ㅇ, head, $\times$ I2. FIG. I3a. Cerceris merope first two tergites, $\times$ I2. FIG. I3b. Cerceris merope pygidium, $\times$ I2. FIG. I4. Cerceris sterope 0 , first three tergites, $\times 12$. FIG. I4a. Cerceris sterope, pygidium, $\times$ I5. FIG. I5. Cerceris celaeno ${ }^{2}$, epinotum and first tergite, $\times$ I2. FIg. I6. Cerceris macalanga 0 , epinotum and first tergite, $\times$ I2. FIG. I7. Cerceris taygete ${ }^{\alpha}$, pronotum, $\times \mathrm{I}_{3}$. FIG. I7a. Cerceris taygete, first two tergites, $\times \mathrm{I} 2$.

temples closely rugoso-punctate. Pronotal dorsum sparsely and not coarsely punctured, the anterior face a little more closely, the sides rugulose and shallowly punctured. Puncturation of the mesonotum, scutellum, and epinotum excepting the sides larger than that of the vertex, the interspaces on the mesonotum half as wide as the punctures, and fully as wide on the epinotum. Mesopleura coarsely reticulatepunctate, metapleura coriaceous, triangular area of the epinotum shining, grooved down the middle, very shallowly transversely rugose.

Puncturation of the tergites I-5 as large as on the epinotum, fairly close but not reticulate-punctate. Pygidial area barrel-shaped, closely rugose, two-thirds longer than wide, the apical margin straight. First and second sternites carinate lengthwise medially, the tumid areas punctured like the tergites. Mandibles with a low broad tooth on the inner margin. Median area of the clypeus as wide as long, its anterior two-fifths inflected, the inflection not extending to the lateral angles, its upper 
margin arcuate and slightly tuberculate in the middle. Inner orbits feebly divergent below. Second joint of the flagellum twice as long as wide, one-third longer than the third joint.

Posterior ocelli about one-fourth farther from the eyes than from each other. Interocular distance on the vertex equal to a little more than the length of the first seven joints of the flagellum. Dorsum of the pronotum as long in the middle as the first joint of the flagellum, the shoulders rounded. Anterior coxae produced outwardly into a blunt cone. Triangular area of the epinotum one-fourth longer than wide at the base. First tergite as long as wide, widest in the middle, the sides convex, as long as the second, the latter four-fifths wider behind than long. Posterior tibiae with five serrations.

o. $8.5 \mathrm{~mm}$. long. Hind tibiae without the apical fuscous streak on the inside, the hind metatarsus pale yellow, the remaining joints brownish-yellow. The puncturation everywhere coarser than in the 9 , especially on the pronotal dorsum, the arcuate and transverse rugae on the epinotal triangle more distinct than in the 9 . The median longitudinal carina on the first sternite does not reach the apical margin, that on the second almost obsolete. Pygidial area wider at the base than at the transverse apex, the sides straight, very little longer than wide at the base. The yellow maculae on the pronotal dorsum smaller than in the , covering only the outer fifths. Median area of the clypeus one-fourth longer than wide. Second joint of the flagellum twice as long as wide at the apex, barely longer than the third, the apical joint slightly longer than the third, and slightly longer than wide at the base, obliquely truncate. Otherwise like the o.

Accra, Gold Coast, September I94I, I 9 ; July, I ô. $^{*}$.

Allied to $C$. placida Arnold from which it differs by the colour, shape of the first tergite, the sculptured triangular area of the epinotum, and in the $q$ also in the shape of the clypeus.

\section{Cerceris sterope sp. $n$.}

\section{(FIgS. I4, I4 $a$; PL. 5, FIG. I3)}

\$. $7 \cdot 5-8 \cdot 5 \mathrm{~mm}$. long. Black. The following parts pale chrome-yellow: clypeus, face excepting a narrow black line dilated above of each side of the frontal carina, a very small spot on each side of the pronotal collar, outer third of the tegulae, a small apical spot on each side of the second tergite, apical bands on the third and fifth tergites, that of the third dilated laterad, the tibiae excepting a black streak on the underside and the base of the metatarsi. Fore and middle tarsi ochreous, the hind pair dark brown. Flagellum dark brown, the second to sixth and the apical joints pale ferruginous below. Wings hyaline, slightly fuscous at the apex, the veins and pterostigma black. Clypeus with decumbent yellowish pubescence, the rest of the body with a sparse, erect, and grey pubescence, long on the head, thorax, and first two tergites. Clypeus shining, shallowly punctured, the interspaces more than twice as wide as the punctures on the anterior half of the median area, the yellow areas of the face a little more closely punctured. Metapleura striato-rugose, the triangular area of the epinotum rugoso-punctate, grooved down the middle, the sulcus margined by a carina on each side; metanotum finely and sparsely punctured. The rest of the 
body coarsely reticulate-punctate, the punctures half as wide as the anterior ocellus, except on the upper part of the face, temples, and sternites, where they are a little smaller. On the scutellum the puncturation is not so close as elsewhere, the interspaces being as wide as the punctures.

Median area of the clypeus one-fifth longer than wide. Second joint of the flagellum one-third longer than wide, very little longer than the third joint. Posterior ocelli half as far again from the eyes as from each other.

Pronotal collar in the middle a little longer than the second joint of the flagellum, the shoulders rounded. First tergite one-fourth longer than wide, nearly as long as the second, the latter not quite one-third wider than long and two and a quarter times wider at the apex than at the base. Second sternite with an ill-defined basal platform. Pygidial area two-fifths longer than wide at the transverse apex, its sides convex. Posterior tibiae with five feeble serrations.

Haramaia, May I948, I o type; Lekempti, May I946, I ${ }_{0}^{\star}$. The specimen from Lekempti lacks the yellow spots on the pronotum.

In the colour of the legs and scapes, and in the shape of the second tergite, this species resembles $C$. macalanga Brauns, but in spite of the difference in the colour of the first two tergites it is more closely related to $C$. nigrostoma Brauns, having like that species the median groove of the epinotal triangle margined on each side by a carina. The genitalia resemble those of nigrostoma and macalanga.

\section{Cerceris celaeno sp. n.}

(FIG. I5, Pl. 5, FIG. I4)

§. $7 \mathrm{~mm}$. long. Deceptively like $C$. macalanga Brauns, but smaller, and differing from it in colour and sculpture as follows: Scape pale yellow below, clypeus and face creamy white or very pale yellow, sparsely and strongly punctured, the interspaces for the greater part three times as wide as the punctures. Triangular area of the epinotum not distinctly grooved down the middle, only with a thin and indistinct line, with four or five punctures near the middle and the lateral margins without the transversely costate grooves which are present in macalanga. Fifth tergite with a narrow pale yellow apical band, interrupted in the middle; in macalanga this segment is entirely black. Sixth tergite also with an apical yellow band, but much narrower than in macalanga. Pygidial area parallel-sided (in macalanga wider at the base than at the apex). Median area of the clypeus more convex than in macalanga, and the lower half of the orbits are parallel, not divergent as in that species. The dorsal aspect of the epinotum is almost semicircular, or about three times wider at the base than long, whereas in macalanga it is semi-ovate, or three-fifths wider at the base than long (Fig. I6). The first tergite is broader, being only one-third longer than wide, and is much less contracted caudad. The outer paramera of the genitalia are relatively shorter, extending barely beyond the apex of the sagittae, and with the widened apical portion much shorter. Otherwise like macalanga Brauns.

Moggio, Ethiopia, June I946, I ô.

I gave a corrected description of macalanga ơ in 1942 (J. Ent. Soc. S. Afr. 5: I2). 
Cerceris taygete sp. $\mathrm{n}$.

\author{
(FIGs. I7, I7a; PL. 5, FIG. I5)
}

o. $7.5 \mathrm{~mm}$. long. Black, the following parts pale yellow: base of the mandibles, clypeus excepting a wide black anterior margin, sides of the face, a small spot on each side of the pronotal collar, outer half of the tegulae, a small subrectangular spot on each side of the second tergite near its base, a transverse band, slightly dilated laterad, on the third tergite, a large triangular spot on each side of the third sternite, the apical half of the sixth tergite, the tibiae, tarsi, and the apex of the fore and middle femora. The tibiae with a black streak on the underside. Antennae brownish-black, the underside of the second to seventh joints reddish. Wings hyaline, the veins and pterostigma brown, the apex of the forewing faintly fuscous. Clypeus with large but not deep punctures, the interspaces larger than the punctures. Metapleura transversely striate, metanotum shining, with a few small punctures. Tumid areas of the sternites with a small and shallow puncturation. The rest of the body deeply reticulate-punctate; the largest punctures are on the thorax and tergites and are about half as wide as the anterior ocellus, those on the vertex and temples a little smaller. Triangular area of the epinotum with a median furrow, and with somewhat indistinct rugae divergent from the base outwardly. Median area of the clypeus fairly convex, one-fifth longer than wide, its apical margin straight and edentate. Dorsum of the pronotum as long in the middle as the second joint of the flagellum, horizontal, the shoulders obtusely angular. Prosternum with a denticle on each side near the middle. First tergite one-third longer than wide, the sides moderately convex, as wide at the base as at the apex.

Second tergite one-fourth longer than the first, three and a half times wider at the apex than at the base. Sixth sternite with a sharp tooth on each side. Pygidial area twice as long as wide, the lateral margins feebly convex, the apical margin straight. Posterior tibiae with six serrations. Outer paramera of the genitalia dilated at the apex, their ventral membraneous portion very large.

Gambeila, Ethiopia, February I948, I o

Related to $C$. inconspicua Arnold, from which it differs by the narrower face, the shape of the first tergite, the black femora, and the genitalia. In inconspicua the median area of the clypeus is only one-ninth longer than wide.

\title{
Subfamily Astatinae
}

Of this subfamily there are two examples of two species, of which one is too damaged to permit of determination. The other is the following:

\section{Astata fuscistigma Cameron}

1905, Rec. Albany Mus. 1: 258, ð.

Accra, Gold Coast, I94I, 2 우우.

It is remarkable to find the range of this species extending to the tropical belt, since hitherto it has been recorded only from South Africa.

ENTOM. 2. 3 
Subfamily NyssoninaE

Alysson guichardi sp. $\mathrm{n}$.

(FIG. I8, I8 $a$, and I $8 b$; PL. 5, FIG. I9)

ㅇ. $9 \mathrm{~mm}$. long. Black. Pronotal dorsum, mesonotum, and scutellum fuscoferruginous. The median area of the clypeus, excepting a black spot in the middle,

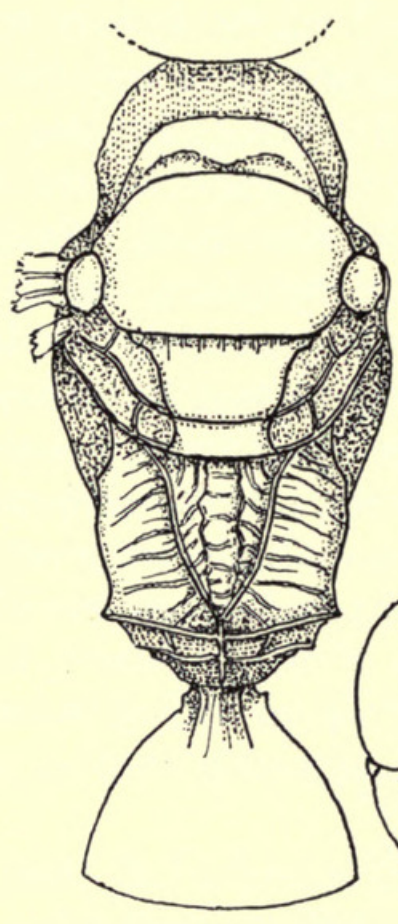

18
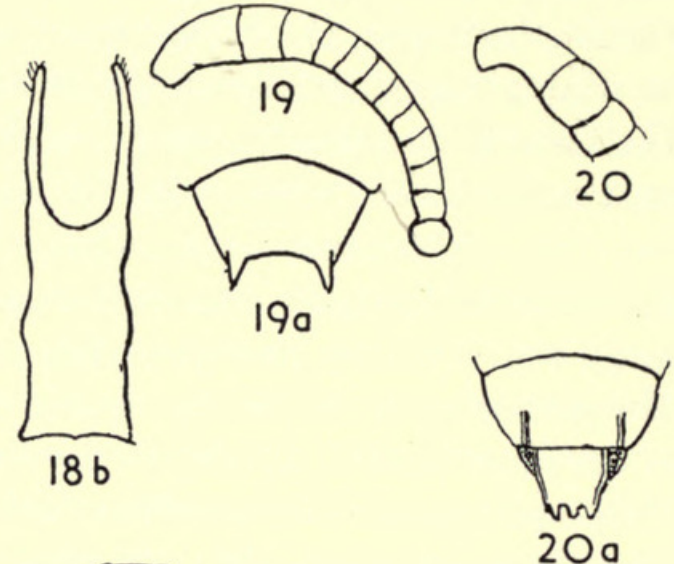

$18 \mathrm{~b}$

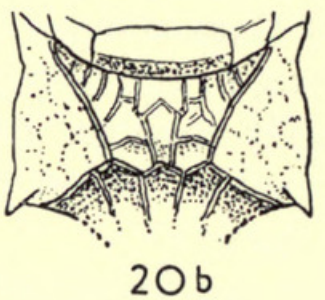

$20 \mathrm{O}$

Fig. I8. Alysson guichardi +, thorax, $\times$ I5. Fig. I8a. Alysson guichardi, head, $\times$ I5. Fig. I8b. Alysson guichardi $\hat{0}$, eighth sternite, $\times c$. 34. FIG. I9. Nysson quadricolor 0 , flagellum, $\times 27$. FIG. I9a. Nysson quadricolor, seventh tergite, $\times 27$. FIG. 20. Brachystegus senegalensis, apical joints of the flagellum, $\times$ I5. FIG. 20a. Brachystegus senegalensis, apical tergites, $\times$ I2. Fig. $20 b$. Brachystegus senegalensis + , epinotum, $\times 12$.

a narrow line on each side of the face, the underside of the scapes, a large, subtriangular macula, the apex mesad, on each side of the second tergite, the underside of the anterior tibiae and the basal two-fifths of the hind femora, creamy white. Last three joints of the anterior tarsi reddish-yellow. A large macula at the middle of the mandibles, pale ochreous. Wings fusco-hyaline, the radial cell darker, the veins and pterostigma blackish.

The lower half of the face with a sparse whitish pubescence, the clypeus, mandibles, declivity of the epinotum, the third and following tergites, and the underside of the femora with a white and very sparse pilosity. Clypeus smooth and shining. Face and temples almost dull, finely and very closely punctured, the interspaces about as large as the punctures. Vertex shining, sparsely punctured with small punctures intermixed with a few larger piligerous ones. Pro- and meso-thorax moderately shining, as finely punctured as the face, but more sparsely, the interspaces for the greater part three to four times wider than the punctures; from each of the latter 
there is emitted a small, erect, and black hair. Metapleura smooth and shining, the metanotum closely, finely, and shallowly punctured. Dorsum of the epinotum onethird wider than long, as wide at the base as at the apex, its lateral margins feebly convex; its median triangular area is defined by strongly raised margins and is as long as wide at the base. The middle third of the triangular area is margined by two zigzagged rugae with transverse rugae between them, and the outer thirds are obliquely costate. The sides of the dorsum outside the median area are transversely rugose, the rugae becoming wider apart and stronger caudad. Posteriorly the dorsum is margined by a strong carina which ends on each side in a broad and low tooth. The declivity has a median carina which nearly reaches the base and at its upper third is joined on each side by an oblique carina ; the space between these carinae is coarsely reticulate-rugose. The sides of the epinotum are closely and obliquely rugose. Abdomen smooth, shining, and impunctate. Pygidial area broadly triangular, rounded at the apex, and clothed with adpressed golden setae.

Mandibles with two widely separated teeth on the inner upper margin. Clypeus short, three and a half times wider than long in the middle, with a deep transverse impression behind the apical margin. Inner orbits slightly divergent dorsad. Posterior ocelli half as far again from the eyes as from each other. Interocular distance on the vertex equal to the length of the first three joints of the flagellum plus two-thirds of the fourth joint. Flagellum slender, the first joint twice as long as wide, the second a little more than four times longer than wide at the apex and one-third longer than the third, all the remaining joints at least twice as long as wide. Pronotum, excluding the neck, four and a half times wider behind than long in the middle, convex transversely and lengthwise, and with a transverse depression in front of the hind margin. Mesonotum one and a half times longer than wide at its widest. First tergite a little wider behind than long, the basal third concave in the middle and divergently striate, the lateral angles dentate. Posterior tibiae with a row of short spines fringed with long white hairs on the upper margin. First abscissa of the radius three times as long as the second, the latter a little longer than the petiole of the second cubital cell.

o. $6.5 \mathrm{~mm}$. long. The whole of the clypeus and the posterior corners of the pronotum, below the tegulae, creamy white. Hind metatarsus also of that colour, except at the base and apex. Otherwise coloured like the + . The puncturation of the head and thorax, in view of the smaller size, is somewhat larger than in the o. The sculpture of the epinotal dorsum, outside the triangular area, is coarser than in the o, and consists of about seven oblique costae with the interspaces transversely rugose. Mandibles with a small tooth on the inner margin behind the apex. First joint of the flagellum subglobose, the second joint one and a half times longer than wide, barely as long as the third, the apical joint truncate at the apex, concave below and twice as long as wide at the base. Interocular distance on the vertex equal to the length of the first four joints of the flagellum plus half of the fifth. First tergite one-fifth longer than wide behind, more deeply concave in the middle of the base than in the ?. Posterior tibiae only feebly spinose. Apical sternite deeply bifurcate, the apical tergite longitudinally rugulose, its apex widely rounded. Otherwise like the o.

Ghedo, Ethiopia, 7,500 ft., May I946, 2 우우, I $\delta^{\text {t. }}$ 
This species differs considerably from the other African species, guillarmodi Arnold, and is more closely related to the European ratzeburgi Dahlbom, from which it differs in the sculpture of the epinotum and the colour of the scutellum and the legs. It is noteworthy that both of the African species inhabit mountainous country.

\section{Nysson quadricolor sp. $\mathrm{n}$.}

(FIGs. I9, I9a; PL. 5, FIG. 20)

․ $5 \mathrm{~mm}$. long. Head black, the base of the mandibles dull yellow, the underside of the scapes and of the first four joints of the flagellum yellowish-white, the rest of the flagellum dark brown. Pronotal collar, except in the middle, pale yellow, the tips of the epinotal teeth translucent and yellowish, the rest of the thorax dark ferruginous, the anterior third of the mesonotum fusco-ferruginous. Tergites I-4 black, the first with a large pale ochreous macula on each side of the apical half, the second to fourth with apical bands of the same colour, narrowly interrupted in the middle, the sternites and the last two tergites ferruginous. Legs fusco-ferruginous, the upper side of all the tibiae yellowish-white, the tarsi reddish-brown. Wings hyaline, the veins black. The whole body dull and with a very short, decumbent, and whitish pubescence, scanty on the tergites. Clypeus finely and closely punctured, transversely impressed behind the straight apical margin. Face with a small and not very close puncturation, the interspaces closely striate lengthwise. The vertex and temples are more deeply and more closely punctured, almost reticulate-punctate; the temples separated from the foramen by a high carina. Inner orbits strongly convergent below, the interocular distance on the vertex being twice as great as across the base of the clypeus, the latter twice as wide as long. Between the antennal sockets there is a transverse torus. Scapes obconical, about half as long again as wide at the apex; flagellum moderately clavate, the first joint transversely ovoid, the second to eighth wider than long, the ninth and tenth as wide as long, the apical one and a half times wider than long. Posterior ocelli very little farther from the eyes than from each other. Pronotal dorsum feebly punctured, its anterior margin convex, the shoulders subdentate. Metapleura smooth, feebly and transversely striate at the base. Dorsum of the epinotum short, in the middle about half as long as the scutellum, with about six oblique carinulae, the lateral angles produced into stout conical teeth. The rest of the thorax coarsely reticulate-punctate. Mesonotum nearly one and a half times wider in front than long, the scutellum twice as wide as long, the sides of the metanotum slightly elevated. Tergites strongly and closely punctured, the punctures a little smaller than those of the mesonotum, the interspaces microscopically striate (40 diameters). Second sternite punctured like its tergite, the other sternites smooth, excepting their apical thirds which are sparsely punctured. Pygidium triangular, the apex rounded, about one and a half times longer than wide at the base. First abscissa of the radius five times longer than the second, a little shorter than the third, the petiole of the second cubital cell half as long again as the second abscissa; the cubitus of the hindwing is emitted from the end of the submedial cell.

o. $5.6 \mathrm{~mm}$. long. Clypeus and the underside of the scapes and of the first six joints of the flagellum pale yellow, the rest of the antennae reddish-brown. Fifth tergite 
with a pre-apical ochreous band as in the preceding tergites, the sixth and seventh ferruginous, the sternites blackish. Clypeus four times wider than long. Flagellum clavate, the second to tenth joints more than one and a half times wider than long, the eleventh wider than long, the apical curved, twice as long as wide at the base, compressed dorso-ventrally at the apex, which is transverse. Shoulders of the pronotum rounded. Apical angles of the seventh tergite spinose. First abscissa of the radius as long as the third. Outer paramera of the genitalia semi-cylindrical beyond the base, widened towards the apex; the sagittae with a semicircular dilatation on the outside at the end of the middle third. Otherwise like the o.

Tillembeya, French Sudan, August I944, I ㅇ, I o*.

Remotely related to $N$. braunsii Handlirsch, from which it differs in colour, sculpture, and in the absence of the angular frontal tubercle behind the inter-antennal torus.

\section{Brachystegus senegalensis sp. $\mathrm{n}$.}

(FIGs. 20, 20 $a$, and 20b; PL. 5, FIG. 2I)

ㅇ. 7·5-10 mm. long. Head and thorax black. Abdomen reddish-brown, the first five tergites with a median triangular black area extending from the base to the apex, and at the basal angles extended to the lateral margins. Clypeus, sides of the face, and the temples covered with a long, dense, adpressed yellowish silvery pubescence, concealing the sculpture; the middle of the face and the vertex with less dense, shorter, and a yellower pubescence, intermixed with setulae. The pronotum, sides of the epinotal dorsum outside the median area, and the basal half of the first tergite also with yellowish silvery pubescence, concealing the underlying sculpture on the epinotal dorsum. A dense adpressed silvery pubescence covers the meso- and meta-sternum, the underside of the coxae and trochanters, femora, and the sternites. On the second sternite a sparse and shallow puncturation shows through the pubescence. Tibiae and tarsi with decumbent silvery pubescence, the hind tibiae also with a row of short spines on the upper outer margin, and also with white setulae. Wings pale fuscous. Face and vertex with a shallow and not close puncturation, the punctures about one-fourth as wide as the anterior ocellus, the interspaces closely and miscroscopically punctured (25 diameters). Epicnemium glabrous and dull. Mesonotum, mesopleura and scutellum deeply pitted, ${ }^{\mathrm{I}}$ the pits about one-third as wide as the anterior ocellus and shining, the interspaces narrower than the pits and closely, microscopically punctured. Metapleura transversely rugose. Median area of the epinotal dorsum divided by carinae into thirteen unequal areolets which are shining. The declivity of the epinotum divided by carinae which converge ventrad into five areolets which are irregularly and transversely costate. Tergites dull, the first five with a fundamental close puncturation (I6 diameters) on which is superimposed a larger sparse and shallow puncturation which becomes progressively finer on each succeeding segment.

Pygidial area closely punctured, nearly twice as long as wide at the base, the apex narrowly rounded. Anterior third of the clypeus inflected, glabrous and shining, the

I By pits are to be understood depressions having flat floors and vertical sides; punctures, on the other hand, have concave floors and sloping sides. 
apical margin feebly convex. Interocular distance on the vertex three-fifths greater than across the base of the clypeus and equal to the length of the first seven joints of the flagellum. Face with a cariniform tubercle between the antennal sockets. Posterior ocelli two-fifths farther from the eyes than from each other. A short longitudinal carina margins the inner orbits of the posterior ocelli; they are more clearly visible when the head is viewed from in front. Second joint of the flagellum one-third longer than wide and as long as the third. Pronotal dorsum in the middle as long as the first joint of the flagellum, its anterior margin obtusely angular in the middle, the shoulders dentiform. Mesopleura with an uneven vertical carina in front of the posterior third, and ending dorsad in a broad, low tooth, just visible from above. Scutellum two-fifths wider than long, its posterior angles rounded. Posterior angles of the epinotal dorsum produced into teeth which are as long as wide at the base. First tergite three-fifths wider than long. As in all the species of the genus, the first sternite has a median longitudinal and shining ridge, ending abruptly before the apical margin and flanked by divergent carinae. First abscissa of the radius fully seven times longer than the second, the latter as long as the petiole of the second cubital cell. Cubitus of the hindwing emitted at a considerable distance beyond the end of the submedial cell.

o. $8 \cdot 2-10 \cdot 5 \mathrm{~mm}$. long. Pubescence on the clypeus and face pale brassy golden. Flagellum fusco-ferruginous, the apical joint yellowish. Second to fifth sternites with apical fimbriae of curved golden hairs, directed cephalad. The black median maculae on the first, third, fourth, and fifth tergites do not reach the apical margin. The red lateral areas on the first and second tergites have traces of ochreous patches. Clypeus a little more than twice as wide as long in the middle, the glabrous inflected anterior third rugose and with two very small teeth on each side near the middle.

Inner orbits more strongly convergent below than in the of, the interocular distance on the vertex being nearly twice as great as across the base of the clypeus. Second joint of the flagellum a little longer than wide, the remaining joints excepting the last increasing gradually in width and all wider than long, the apical joint curved, compressed dorso-ventrally, and truncate at the apex. Sixth tergite with a longitudinal carina on each side near the lateral margins and extending only over the apical half of the segment. Pygidial area sharply carinate on the lateral margins, twice as wide at the base as at the apex, strigose lengthwise and closely punctured, the apex with three strong teeth. Otherwise like the o.

Diafarabé, French Sudan, August I944, 2 우우, 2 충.

Nearest to $B$. decipiens Arnold, from which it is distinguished, inter alia, by the colour of the wings, legs, and abdomen, the feeble tubercle on the face, and the absence of teeth on the inferior margin of the mesopleura.

\section{Brachystegus senegalensis var. aurantiacus var. $n$.}

ㅇ. $9.5 \mathrm{~mm}$. long. Black. Tibiae and tarsi reddish-brown, the extreme base and apex of the anterior tibiae pale ferruginous. Tergites I and 2 with triangular orange maculae on each side, occupying more than the apical half of the segments, tergites 3-5 with apical bands, interrupted in the middle and dilated laterad and of the same colour. Wings pale fuscous. Pubescence and sculpture like that of the species, 
excepting the tomentum on the second sternite which is much less dense and distributed in little separated patches.

o. $7.5 \mathrm{~mm}$. long. Colour as in the o. The decumbent pubescence on the sides of the epinotal dorsum is very sparse and absent on the basal half of the first tergite. Scutellum not so wide as in the type of the species, being only one-fifth wider than long, and with the lateral margins more convex.

Tillembeya, French Sudan, August I, ㅇ, September I944, I ot.

There is so little difference between this variety and the smaller $\sigma^{t}$ and $o$ of the species, except in the colour of the tergites, that it might be suspected that the colour in senegalensis has been affected by the vapour of cyanide. However, yellow colours are turned to bright red by cyanide and not to a reddish-brown. Moreover, in the $\sigma^{t}$ of aurantiacus the sternites are without fimbriae.

Gorytes thalia montivagus subsp. $\mathrm{n}$.

$$
\text { (PL. 5, FIG. 22) }
$$

G. thatia Handlirsch, I895, S.B. Akad. Wiss. Wien, 104: ro23 우 ; 901, Verh. Zool. bot. Ges. Wien, 51: 427, ơ, ㅇ․

6. $7.5 \mathrm{~mm}$. long. This differs from the type of the species as follows. Flagellum black. Yellow areas on the sides of the face narrower and abruptly contracted above. The spot on the posterior angles of the mesonotum yellow instead of red. Hind tibiae black on the inside. Hind tarsi with the basal joint and the basal half of the second joint pale yellow, the rest black. Apical margin of the fifth tergite rufescent, without a yellow band. Apical joint of the flagellum longer, three-fifths longer than wide at the base. Outer paramera of the genitalia narrower and blunter at the apex. The genitalia are peculiar, having a membranous velum connecting the outer and inner paramera, and, apparently, also the base of the sagittae. Between the inner and outer paramera the margin of the velum is produced into a short, curved and chitinized tooth.

․ $7.5 \mathrm{~mm}$. long. Middle and hind tibiae fusco-ferruginous, yellow on the outside. Hind tarsi fusco-ferruginous. Pygidial area scutate, narrowly truncate at the apex, nearly half as long again as wide at the base (as wide there as long in thalia i. sp.). Clypeus shorter, the apical margin straight and with a feeble median emargination.

River Hawash, 6,000 ft., Ethiopia, June, I946, I ô, I 9 .

The colour of the legs in the $\sigma^{t}$ is like that of G. emeryi Grib., but the epinotum is not 'densely, coarsely punctured, and sub-reticulate'.

\section{Ammatomus spiniferus Du Buysson var. latus var. n.}

A. spiniferus Du Buysson, I897, Ann. Soc. Ent. France, 66: 359, ㅇ.

This variety differs from the type of the species only in having the puncturation of the mesonotum a little deeper and denser, and in the wider abdomen.

The first tergite is as wide behind as long, and the second three-fourths wider at the apex than at the base. In spiniferus i. sp. the first is one-fourth longer than wide behind, and the second is nearly twice as wide at the apex as at the base.

Didessa River, Ethiopia, 4,000 ft., May I946, 2 웅․ 
Subfamily Stizinae

tridens group

Stizus braunsii Handlirsch

1894, Ann. naturh. Hofmus. Wien, 9: 287.

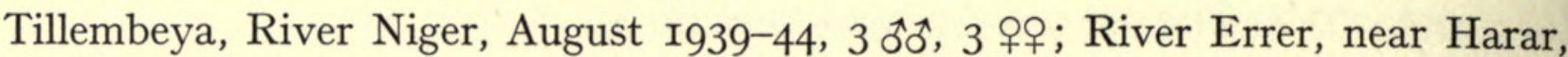
Ethiopia, May I948, 2 ธิ乛ే.

In Ann. Transv. Mus. 20 (2), I940, Pl. V, figures were given of the genitalia of ten species of this very difficult group. Further examination shows that the degree of chitinization of the basal portion of the outer paramera and the width of the apical portion are somewhat variable.

\section{Stizus haemorrhoidalis Handlirsch}

I90o, Verh. Zool. bot. Ges. Wien. 50: 472.

Dilla, Ethiopia, April I948, 2 춧․

\section{Stizus multiguttatus sp. $\mathrm{n}$.}

(FIGS. 2I, 2I $a$, and 2I $b$ )

o. 8.5-9 mm. long. Related to $S$. braunsii Handlirsch, but larger and with more extensive and deeper yellow markings. Sculpture like that of braunsii.

Black. The following parts are chrome-yellow: mandibles excepting the apex, labrum, clypeus, face below the antennal sockets, and a narrow line on each side of the lower half of the face, scapes, underside of the first two joints of the flagellum, upper half of the pronotum including the tubercles, lateral margins of the mesonotum, tegulae, upper two-thirds of the mesopleura, a large more or less polygonal spot on each side of the scutellum, metanotum, posterior angles of the epinotum, a more or less semicircular macula on each side of the first tergite not reaching the apical margin, apical bands on the second to fifth tergites, bisinuate cephalad and abruptly, widely dilated laterad, an oblong macula on each side of the sixth tergite, lateral maculae on the second to fifth sternites, that on the second very large, underside of the coxae and trochanters, and all the legs excepting the basal third of the hind femora.

Upper side of the flagellum blackish, the underside, excepting the first two joints, pale ferruginous. Wings hyaline, the veins dark brown. Clypeus at its widest fivesevenths wider than long. Interocular distance on the vertex two and three-quarter times greater than across the base of the clypeus, the inner orbits therefore more convergent than in braunsii.

Third joint of the flagellum longer than in braunsii, being barely (one-eighth) shorter than the second, the latter nearly twice as long as wide. The three apical joints of the flagellum like those of braunsii, seventh tergite much less attenuated towards the apex than in braunsii (Fig. 2I c). The outer paramera of the genitalia much wider than in braunsii.

ㅇ. 8-Io $\mathrm{mm}$. long. Second cubital cell not petiolated, the first and second transverse cubital veins meeting on the radius. Sixth tergite entirely black, and all the 
femora have a black streak on the upper side at the base. Otherwise like the $\sigma^{t}$ in colour, but the apical bands of yellow on the tergites are less deeply bisinuate on their anterior margin.

In one of the 3 우, the yellow bands are much reduced on the second and following tergites.

Second joint of the flagellum twice as long as wide, one-fourth longer than the third. Otherwise like the $\hat{\delta}$.

Tillembeya, River Niger, French Sudan, August I944, 5 충ㅅ, 3 웅․

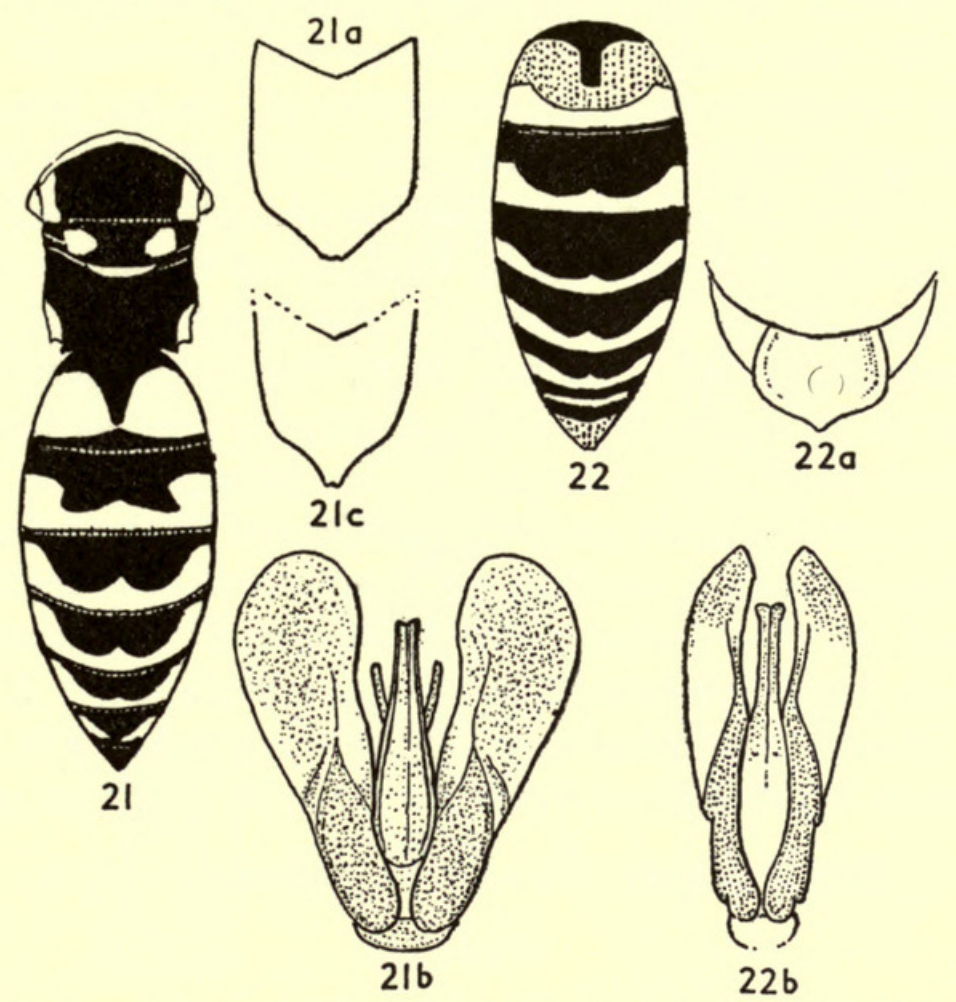

FIg. 21. Stizus multiguttatus $\hat{\delta}, \times 6$. FIg. 2 Ia. Stizus multiguttatus $\hat{\delta}$, seventh tergite, $\times c$. ro. FIG. 2Ib. Stizus multiguttatus, genitalia, $\times c$. 22. Fig. 21c. Stizus braunsii ${ }^{\star}$, seventh tergite, $\times$ c. Io. Fig. 22. Stizus sudanensis $0^{\star}$, abdomen, $\times 4$. FIg. 22a. Stizus sudanensis, seventh sternite, $\times c$. I2. FIG. 22b. Stizus sudanensis, genitalia, $\times 16$.

\section{Stizus corpulentus Arnold}

1929, Ann. Transv. Mus. 13: 270.

1939, Occ. Pap. Rhod. Mus. 5: 27.

Lake Bishoftu, 7,000 ft., Ethiopia, May I946, I ‥ A slight variety in which the clypeus is entirely black, and the pale bands on the abdomen are glaucous white instead of yellow.

$$
\text { discolor group }
$$

Stizus sudanensis sp. $\mathrm{n}$.

(FIGS. 22, 22a, and 22b)

6. I2 mm. long. Black. Lateral margins of the mesonotum, and of the epinotum, first tergite excepting a median black T-shaped area at the base, and seventh tergite, ferruginous. Sternites fusco-ferruginous. The following parts are yellow: mandibles 
excepting the apex, labrum, clypeus, face below the antennal sockets, a narrow line on the lower half of the sides of the face, scapes, upper half of the pronotum, a triangular macula on each side of the scutellum, apical bands on the first six tergites dilated laterad and also slightly and angularly in the middle, and apical bands on the second to sixth sternites more or less interrupted medially.

Legs yellow, middle and hind femora flavo-ferruginous. Flagellum dark brown above, flavo-ferruginous below.

Wings hyaline, slightly yellow, the veins dark brown. Clypeus and lower half of the face with decumbent silvery pubescence. The puncturation on the head and thorax, excepting the epinotum, is very shallow and microscopic. On the epinotum outside the median triangular area the punctures are larger, less oblique, and closer, the interspaces being as wide as the punctures. The abdomen has the fine oblique and shallow puncturation common to the species of the genus. Clypeus twice as wide in front as long. Interocular distance on the vertex very nearly twice as great as across the base of the clypeus. Second joint of the flagellum nearly three times longer than wide and one-sixth longer than the third, the three apical joints as in nyasae Turn. but the spine on the tenth joint is less angularly bent at the apex. Ocelli as far from the eyes as from each other. Dorsum of the epinotum short, not longer than the scutellum. Seventh sternite fairly strongly punctured in the basal half, concave, the lateral margins being somewhat swollen, without a median tubercle. Anterior femora strongly compressed. First abscissa of the radius three times longer than the second.

Tillembeya, River Niger, French Sudan, September I944, I to.

Like $S$. nyasae Turner, the other member of this group, this species differs from $S$. discolor Handlirsch in the lack of a median tubercle on the seventh sternite.

\section{Stizus nyasae Turner var. robustus var. $n$.}

(FIG. 23)

S. nyasae, Turner, 1912, Ann. Mag. Nat. Hist. 10: 338.

o. I3 $\mathrm{mm}$. long. This variety differs from the type of the species only in the greater size and extent of the yellow colour. The two small yellow lines on the disk of the mesonotum which are present sometimes in nyasae are here developed into two large longitudinal bars extending over the anterior two-thirds of the segment. The scutellum is black only over its anterior third, and the whole of the epinotum is yellow excepting a narrow black basal band on the triangular area, and narrow black borders outside and adjacent to the lateral margins of that area. In three of the four specimens the yellow areas of the tergites are not crenulate as in the type of the species $;{ }^{\mathrm{I}}$ their anterior margins are less indented on the second and third tergites and on the remaining tergites larger.

The genitalia are identical. The outer paramera have a narrow dorsal face, and a wider outer face.

ㅇ. I2 $\mathrm{mm}$. long. One specimen of this sex, from the same locality as the males, differs from the + of typical nyasae in having all the black parts replaced with ferruginous.

Tillembeya, River Niger, French Sudan, September I944, 4 ठㅊㅎ, I ㅇ.

I The heraldic term 'vair' accurately describes the arrangement of the colour in nyasae i. sp. 


$$
\text { caffer group }
$$

\section{Stizus laterimacula fraudulentus subsp. $\mathrm{n}$.}

(FIG. 24)

S. laterimacula Handlirsch 1895, S.B. Akad. Wiss. Wien, 104: 980.

o. II-I2 mm. long. Smaller than laterimacula i. sp., and with a very different colour pattern on the abdomen, but with the genitalia barely distinguishable.

Puncturation and pubescence as in the type of the species. Black. The following parts pale chrome yellow: mandibles, labrum, clypeus, face below the antennal

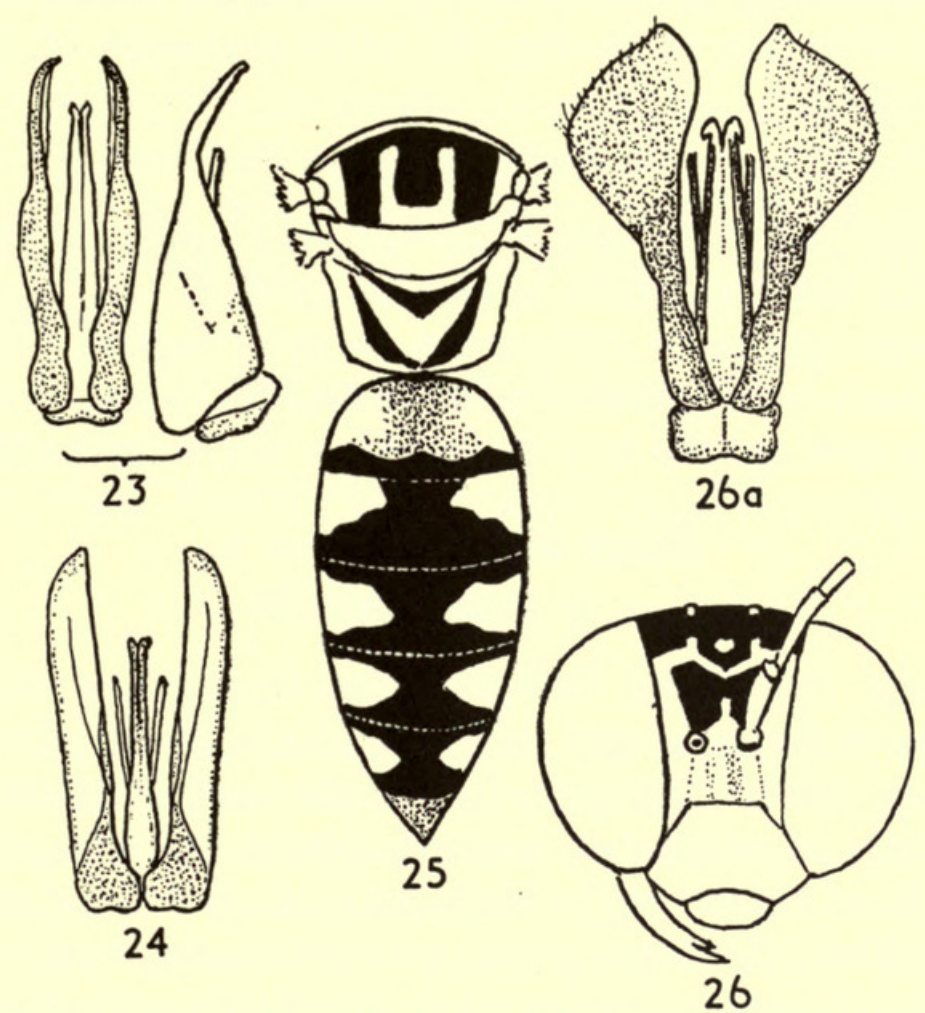

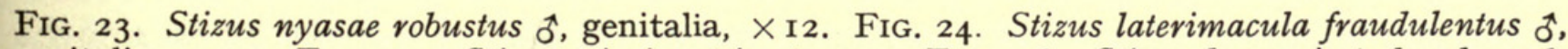

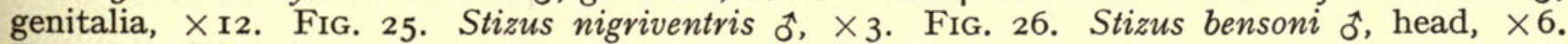
FIG. 26a. Stizus bensoni, genitalia, $\times$ I2.

sockets and at the sides and a broad median line reaching the anterior ocellus, scapes, a narrow line on the temples adjacent to the eyes, upper half of the pronotum including the tubercles, sides of the mesonotum, upper half of the mesopleura and a triangular macula below it, subtriangular and transverse maculae on each side of the scutellum, the metanotum, two oblong spots on the median area of the epinotum, the outer half of the sides of the epinotal dorsum and the lateral margins of the declivity, lateral semi-elliptical maculae on the first tergite, apical bands on the second to sixth tergites crenulated and similar to those of $S$. nyasae and S. loriculatus, an indistinctly margined median macula on the seventh tergite, small transverse maculae on the second to sixth sternites and the legs. The femora pale rufous on the upper side. Flagellum ferruginous. The apical margins of the sternites are pale brown. Wings hyaline, tinged with yellow, the veins yellowish-red.

The inner orbits are a little more convergent below than in laterimacula and the 
var. euteles, the interocular distance on the vertex being three-fifths greater than across the clypeus, and the anterior margin of the latter is concave and not straight as in the others. As in all the species of this group the hind tibiae are transversely compressed and curved outwardly. The genitalia are almost identical with those of laterimacula i. sp., the only difference being the slightly more rounded apex of the outer paramera and the heavier chitinization of the inner margin.

Kaffrine and Kaolack, Senegal, August I943, 2 충.

On account of the colour pattern of the abdomen, this insect could easily be mistaken for nyasae or a small loriculatus. It may be noted here that euteles Handlirsch, which I reduced to a variety of laterimacula (I929, Ann. Transv. Mus. 13:282) differs from the latter and this race in having the outer paramera of the genitalia densely pilose on the underside.

\section{fasciatus group}

The majority of the species in this group are very similar in the female sex, and a revision based on the male genitalia is greatly needed, and would probably reduce some of the supposed species to subspecific, or even varietal, rank. Unfortunately the $\delta \hat{o}$ of some of them are at present unknown. It is therefore with some hesitation that I describe as a new species two 우우, without the corresponding 0 .

\section{Stizus nigriventris sp. $\mathrm{n}$.}

\section{(FIG. 25)}

ㅇ. $20-23 \mathrm{~mm}$. long. Mandibles excepting the black apex, labrum, clypeus, face at the sides and below the antennal sockets and the whole of the outer half of the occiput pale ochreous yellow, the inner half of the occiput black. The yellow at the sides of the face with an extension inwards almost enclosing the anterior ocellus. The dorsum of the thorax is mainly reddish ochreous, but the upper two thirds of the pronotum is pale yellow; the black areas are: the mesonotum excepting the lateral margins and a large rectangular $U$-shaped median area extending from the anterior to the posterior margin, a short triangular band on the base of the median area of the epinotum and the inner half of each side of the epinotal declivity. Meso- and metapleura black, excepting a large macula covering the upper two-thirds of the former, and an oblong macula on the upper half of the metapleura. The underside of the thorax, including the coxae and trochanters, is entirely black. First tergite pale ferruginous, with a large and distinctly defined yellow macula on each side and a black apical band angularly dilated laterad. Second to fifth tergites black with large subtriangular maculae on each side, their apices mesad. Sixth tergite ferruginous, covered with a dense reddish-golden pubescence. Sternites entirely black. Legs and antennae flavo-ferruginous. Wings flavo-hyaline, the veins flavo-ferruginous, the radial, second and third cubital cells, and apical half of the second discoidal cell, fuscous. Clypeus and face with a silvery pubescence, the thorax with a very short greyish and inconspicuous pubescence. Head and thorax dull, microscopically reticulate-punctate, the labrum and anterior half of the clypeus less dull and a little more strongly punctured. Tergites I to 5 moderately nitid, very shallowly, finely and closely punctured. Sternites dull, microscopically reticulate and with a very sparse 
and shallow puncturation superimposed. Clypeus a little more than twice as wide as long, the anterior margin moderately concave.

Inner orbits subparallel over the lower two-thirds. Interocular distance on the vertex equal to the length of the first two joints of the flagellum plus four-fifths of the third and only one-fifth greater than the interocular distance across the base of the clypeus. Second joint of the flagellum not quite five times longer than wide at the apex, and fully twice as long as the third. Apical joint slightly curved, a little longer than wide at the base. Posterior ocelli two-thirds farther from each other than from the eyes. Pygidial area not marginate, triangular, narrowly rounded at the apex. First abscissa of the radius slightly longer than the second. Basal joint of anterior tarsi with six spines.

Tillembeya, River Niger, French Soudan, September I944, 2 우.

This differs from aurifluus and multicolor, rubroflavus, and rubellus Turner in the colour of the dorsum of the thorax, especially the V-shaped macula of the mesonotum, and the entirely black sternites. The clypeus is not deflected in the anterior half as it is in rubroflavus.

1844, Icon. Règne anim.: 438.

\section{Stizus basalis Guérin}

Tillembeya, River Niger, French Sudan, Sept. I944, I đ^, 3 우우.

\section{Stizus bensoni sp. $n$.}

(FIGs. 26, 26a)

๙. I7 mm. long. Black. The following parts are bright chrome-yellow: basal half of the mandibles, labrum, clypeus, lower half of the face, a line on the sides of the face joining a transverse $M$-shaped bar above, a line on the temples margining the posterior orbits, two small spots on the posterior margin of the vertex, the upper margin of the pronotum including the tubercles, the lateral margins of the mesonotum narrowly, a subtriangular macula on each side of the scutellum, the metanotum, narrow lines margining the median area of the epinotum but not meeting at the apex, an oblong spot on the upper angles of the epinotal declivity, transverse bands, widely interrupted mesad and widest laterad on the first six tergites. Seventh tergite fuscoferruginous and with pubescence of the same colour. Sternites I-6 black, the apical margins brownish-yellow, narrowly on the first three, more widely on the fourth to sixth, the seventh sternite fusco-ferruginous. Legs and flagellum ferruginous, the coxae and trochanters black. Wings hyaline tinged with yellow, the veins reddishyellow. Head and thorax with exserted yellowish-grey pubescence, fairly long on the epinotum. Head and thorax dull, the sides of the epinotum nitidulous. Clypeus and face and vertex microscopically and very closely punctured, pronotum almost smooth, the rest of the dorsum of the thorax very finely, obliquely and closely punctured, the interspaces barely larger than the punctures except on the anterior third of the mesonotum where the puncturation is sparser. Mesopleura as closely punctured as the mesonotum, but the punctures are round and a little larger. Metapleura and sides of epinotum almost smooth. Tergites nitidulous, less closely and more obliquely punctured than the mesonotum, the sternites less closely than the tergites. 
Clypeus distinctly convex lengthwise, nearly six-sevenths wider than long, the anterior margin concave. Face below the antennal sockets slightly raised in the middle, but not subcarinate. Inner orbits feebly convergent below; the interocular distance on the vertex equal to the length of the first three joints of the flagellum plus half of the fourth and one-fourth greater than the least distance between the eyes below. Posterior ocelli not quite twice as far from each other as from the eyes. Second joint of the flagellum slender, curved, five times longer than wide at the apex and two-thirds longer than the third joint. Apical joints twice as long as wide at the base, concave below, curved, rounded at the apex. Declivity of the epinotum feebly concave. Seventh tergite widely rounded at the apex. First cubital vein straight, first abscissa of the radius a little shorter than the second. Outer paramera of the genitalia flat and lamelliform in the apical half, the outer margin almost semicircular.

Koundé-Saré, River Niger, French Sudan, August I945, I o .

Although the first transverse cubital vein is straight as in the ruficornis group, this species is evidently closely related to imperialis Handlirsch, as is seen by the shape of the genitalia. In imperialis the outer paramera are not so widely dilated as in this species and with the outer margin of that part bluntly angular instead of semicircular (I936, Occ. Pap. Rhod.Mus. 5: I5, fig. 6). Named after Mr. R. B. Benson, Department of Entomology, British Museum (Natural History).

\section{Stizus ferrugineus Smith}

1856, Cat. Hymen. B.M. 4: 342 .

Meisso, Ethiopia, August I945. I $\widehat{0}$.

Stizus ritzemae Handlirsch

1895, S.B. Akad. Wiss. Wien, 104: 1000, ㅇ․

Accra, Gold Coast, September I94I, I ㅇ.

This specimen agrees fairly well with Handlirsch's description, but the first tergite is entirely ferruginous.

In the absence of the $\delta^{t}$ a comparison of the genitalia is not possible, but I strongly suspect that ritzemae is only a colour variety of ferrugineus Sm.

tridentatus group

\section{Stizus amoenus Smith}

1856, Cat. Hymen. B.M. 4: 338.

Tillembeya, River Niger, French Sudan, September I944, I o .

1844, Icon. Règne anim. 438.

Stizus mionii Guérin

Koundé-Saré, River Niger, French Sudan, August I945, I 우, 5 ổ.

Subfamily Bembicinae

In the descriptions of new species which follow I have not given a lengthy and detailed account of the colour pattern since I am of the opinion that that can be more 
easily appreciated by illustrations in the text-figures. There are, of course, minor individual variations, but on the whole there is a basic pattern peculiar to each species.

In the descriptions of new species of this genus I have had occasion to refer to other African species, comparing the genitalia and the colour-pattern of the tergites. The reader should therefore refer to my monograph of the African Sphecidae (I929, Ann. Transv. Mus. 13 (4)) in which figures of the genitalia have been given of the majority of the species, and to the plate illustrating the pattern of the tergites. In this genus the outer paramera of the genitalia have a ventral membranous ramus which in the natural state cannot be seen from the dorsal aspect (see Figs. $27 b$ and $28 b$ ) but which is made visible if pressure is applied to the base of the dorsal rami so as to splay them out.

The collection contains females of three or four possibly new species which, in the absence of any striking specific character, it would be unwise to name and describe in the absence of the other sex.

\section{Bembix splendida sp. n.}

(FIGS. 27, 27a and 27b)

๙. $20 \mathrm{~mm}$. long. Mandibles, labrum, clypeus excepting a bi-arcuate black macula covering the basal two-thirds, sides of the face up to the level of the anterior ocellus, pale yellow. The rest of the face and the vertex, excepting a quadrate black macula covering the ocellar area, flavo-ferruginous. Occiput black, the outer part, widening ventrad, flavo-ferruginous above, merging into pale yellow below. Clypeus with silvery pubescence, the rest of the head with a long, fairly dense, erect and greyish pubescence. Pronotum ferruginous, the rest of the thorax black, with the following parts deep lemon-yellow; a narrow transverse band on the posterior half of the scutellum, the basal half of the metanotum, a wide V-shaped area margining the median epinotal area and large triangular maculae, the apex mesad, on the posterior angles of the epinotal dorsum. Lateral margins of the mesonotum and the tegulae pale ferruginous. Mesonotum and scutellum with erect yellowish-grey pubescence, the rest of the thorax, including the pleura and sterna, with a long, erect, abundant and whitish pilosity. Tergites I- 6 yellow, the extreme base and apex of each one black, the yellow areas enclosing a black spot on each side of the middle, on the first and second, the spots on the third to fifth quadrangular and contiguous with the basal black margin. The base and apex of the sixth and the whole of the seventh, pale ferruginous. Sternites black, the second to fourth with a small lateral yellow maculae. Abdomen with a decumbent, short and yellowish pubescence. Antennae and legs, not including the coxae and trochanters, ferruginous, the apical joints of all the tarsi, excepting the extreme base, black. Wings clear hyaline, the veins brown.

Labrum and clypeus slightly shining, sparsely and finely punctured. Dorsum of the thorax dull, densely and very finely punctured, the punctures round. Pleura and sterna dull, closely punctured, the punctures oblique and a little larger than those of the mesonotum. Tergites nitidulous, finely, obliquely punctured, the interspaces about three times wider than the punctures. Sternites shining, the second with a 
smooth, very sparsely punctured median triangular area ending in a short carina, truncate or dentiform at its apex, the sides are closely and obliquely punctured, the following sternites less strongly punctured, the sixth with a raised semi-elliptical platform, acute at the apex, the seventh with a shining median carina. The seventh tergite is sparsely and coarsely punctured, abruptly attenuated near the apex.

Clypeus twice as wide as long, subcarinate at the base, the apical margin concave. Inner orbits moderately divergent below the middle. Interocular distance on the
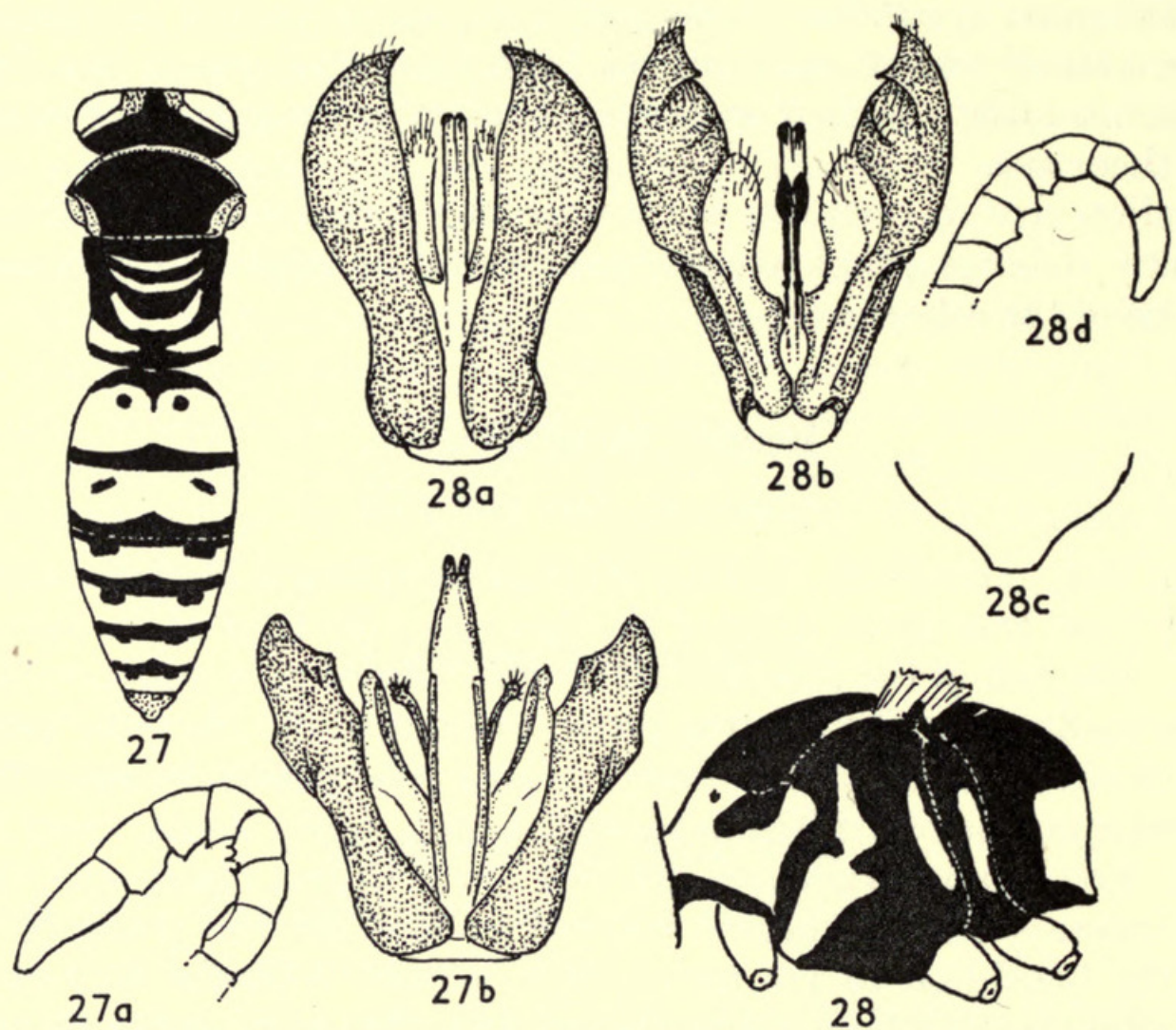

Fig. 27. Bembix splendida $\delta^{*} \times$ c. 2.7. FIG. 27a. Bembix splendida, apical joints of flagellum, $\times$ I3.5. Fig. 27b. Bembix splendida, genitalia, $\times$ I4.5. Fig. 28. Bembix fantiorum 0 , thorax, $\times 7 \cdot 5$. Fig. $28 a$ and $b$. Bembix fantiorum, genitalia, dorsal and ventral view, $\times 13.5$. Fig. $28 c$. Bembix fantiorum ${ }_{0}$, apical tergite, $\times$ I2. FIg. $28 d$. Bembix fantiorum ${ }^{*}$, apical joints of the flagellum, $\times 13.5$.

vertex equal to the length of the first two joints of the flagellum plus four-fifths of the third. Second joint of the flagellum four times longer than wide, and three-fifths longer than the third, the sixth and following joints excavated below, the seventh bidentate on the outer margin, the apical acuminate, two and a half times longer than wide at the base. Anterior coxae for the greater part pale yellow. Middle metatarsi dilated below near the base. Middle femora not dentate on the hind margin.

Koundé-Saré, River Niger, French Sudan, August I945, 3 \$ิో

Related to ugandensis Turner, from which it differs by its smaller size, ferruginous legs and antennae, the round puncturation of the thorax, the colour of the last four tergites, the unarmed middle femora, and the genitalia.

This species belongs to the diversipennis group. 
melanopa group

Bembix fantiorum sp. $\mathrm{n}$.

(FIGS. 28, 28a-d)

o. I4-I5 mm. long. Black. The following parts are pale yellow: the sides of the labrum and clypeus to a varying degree, sometimes the former has only the median third black, and the clypeus may be entirely black, the sides of the face, two small spots below the ocellar area, the outer orbits, mandibles excepting the apex, pronotum, lateral margins of the mesonotum and sometimes two longitudinal streaks on the anterior half of the same, sometimes the hind margin of the scutellum, the greater part of the mesopleura, the metapleura excepting the margins, and the anterior and posterior thirds of the sides of the epinotum.

First five tergites in the middle with transverse bands of glaucous white, becoming yellower laterad, bisinuate cephalad, and more or less interrupted in the middle; the sixth tergite with two whitish spots. The shape of these bands is like that of melanopa, and as in that species the yellow band on the second tergite sometimes encloses a black spot on each side (see Ann. Transv. Mus. 13, I929, Pl. 4, figs. I6 and I7).

Sternites 2-5 with triangular yellow maculae at the sides. Antennae black, the last three joints ochreous below. Legs yellow, coxae and trochanters partly black, the underside of the fore and middle tarsi black, the anterior femora on the upper side and the anterior tibiae both above and below with black streaks, the middle and hind femora with small black streaks above near the apex and at the base below, the middle and hind tibiae with black streaks above and below. Wings clear hyaline.

Labrum and clypeus with a few scattered punctures.

Thorax dull, closely and obliquely punctured, tergites nearly dull, a little more finely punctured than the thorax. Sternites shining, coarsely and obliquely punctured, the second more densely so than the rest.

Clypeus very convex, two-thirds wider than long. Inner orbits slightly divergent below. Second joint of the flagellum three times longer than wide and half as long again as the third, the fifth to ninth spinose, the last three concave below. Middle femora with about eight teeth on the apical half of the hind margin. Tarsal comb with yellow spines, of which there are six on the basal joints. Second and sixth sternites as in melanopa, the seventh more narrowed in the apical part than in that species. The seventh tergite, coarsely punctured, is more narrowed apically than in that species and the apex is widely rounded.

ㅇ. $15 \mathrm{~mm}$. long. Mesonotum with a large $U$-shaped yellow macula, rectangular at the base. Hind margin of the scutellum and metanotum, and the posterior half of the median area of the epinotal dorsum, yellow. First tergite sometimes with two triangular yellow maculae on the declivious anterior face. The yellow bands on the second and third tergites usually enclose transverse black maculae, and the band on the first is usually entire. The sixth tergite is entirely black and more coarsely and more closely punctured than in the $\delta$, its lateral margins not sinuate, the apex narrower than in the other sex. The second sternite is closely punctured at the sides, much more coarsely and very sparsely in the middle. The black streak on the upper side of the hind femora is longer and wider than in the $\sigma^{t}$. 
Otherwise like the $\sigma^{*}$ in colour, sculpture, and pilosity.

Second joint of the flagellum three and a half times longer than wide, and about one-third longer than the third joint. Apical joint moderately curved, compressed dorso-ventrally at the apex, and nearly three times longer than wide at the base. Tarsal comb fusco-ferruginous.

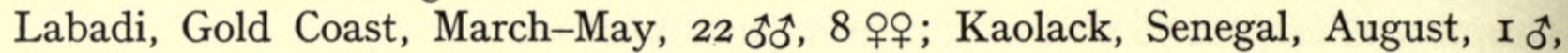
2 우우 ; Tillembeya, River Niger, September, 2 주, 2 우오.

This is not melanopa, race forcipata Handlirsch (which is also richly yellow on the pleura), since, according to Handlirsch, the genitalia do not differ from those of the type of the species, but it is more closely related to melanopa i. sp. than to any other, in spite of the difference in the genitalia.

The species is named after the major native tribe of the Gold Coast.

\section{Bembix guigliae sp. $\mathrm{n}$.}

(FIGS. 29, 29a-c)

f. I4-I6 mm. long. Black. Mandibles excepting the apex, labrum, clypeus at the sides and on the anterior margin, outer orbits more widely below than above, sides of the face, the bottom of the face above the antennal sockets, and a transverse bar with irregular margins below the ocellar area, yellow.

Underside of the scapes yellow, the upper side and the flagellum excepting the last three black joints ferruginous.

The yellow markings on the thorax are very much the same as those of the $q$ of the preceding species, fantiorum q.v., excepting that the U-shaped macula on the mesonotum is absent, and the maculae on the pleura are less extensive. The yellow is also of a deeper colour, deep chrome-yellow. The pattern of the deep chrome-yellow markings on the first five tergites is also very similar to those of fantiorum, but the enclosed transverse black maculae are often continuous with the basal black area on the second tergite and always so on the third. Sixth tergite black at the base, the apical third ferruginous, seventh tergite fusco-ferruginous, with the basal third black. Sternites I- 6 fusco-ferruginous in the middle, blackish laterad, the second to fifth with triangular yellow maculae at the sides; sixth sternite black over the basal half, and ferruginous on the apical. Legs yellow, the anterior tibiae with an oblong black macula on the underside, the fore and middle femora with a black streak above, and a short one on the underside at the base; the hind femora have only a black and short macula at the base. Wings hyaline, tinged with yellow, the forewing slightly darker over the basal half but not distinctly infuscated. Clypeus with adpressed silvery pubescence, the rest of the head, the thorax, and base of the first tergite with a long erect and yellowish-white pilosity.

The sculpture of the head, thorax, and tergites is like that of B. fuscipennis Le Peletier but a little finer. The puncturation of the sternites is deeper and more dense, especially on the second which has a ferruginous, compressed, and curved tooth like that of fuscipennis. The raised scutate platform on the sixth is narrower at the base than in fuscipennis.

The seventh sternite differs considerably from that of fuscipennis; the basal half 
is slightly flattened in the middle and the apical half is depressed, marginate over the basal half of its sides, and subcarinate in the middle. Basal joint of middle tarsi dilated basad as in fuscipennis. The antennae as in that species, but the tenth and eleventh joints of the flagellum are distinctly shorter. Middle femora without teeth on the hind margin.

ㅇ. I4 $\mathrm{mm}$. long. Sixth abdominal segment ferruginous, the yellow margin on the sides of the face and the transverse band below the ocellar area often broken up into
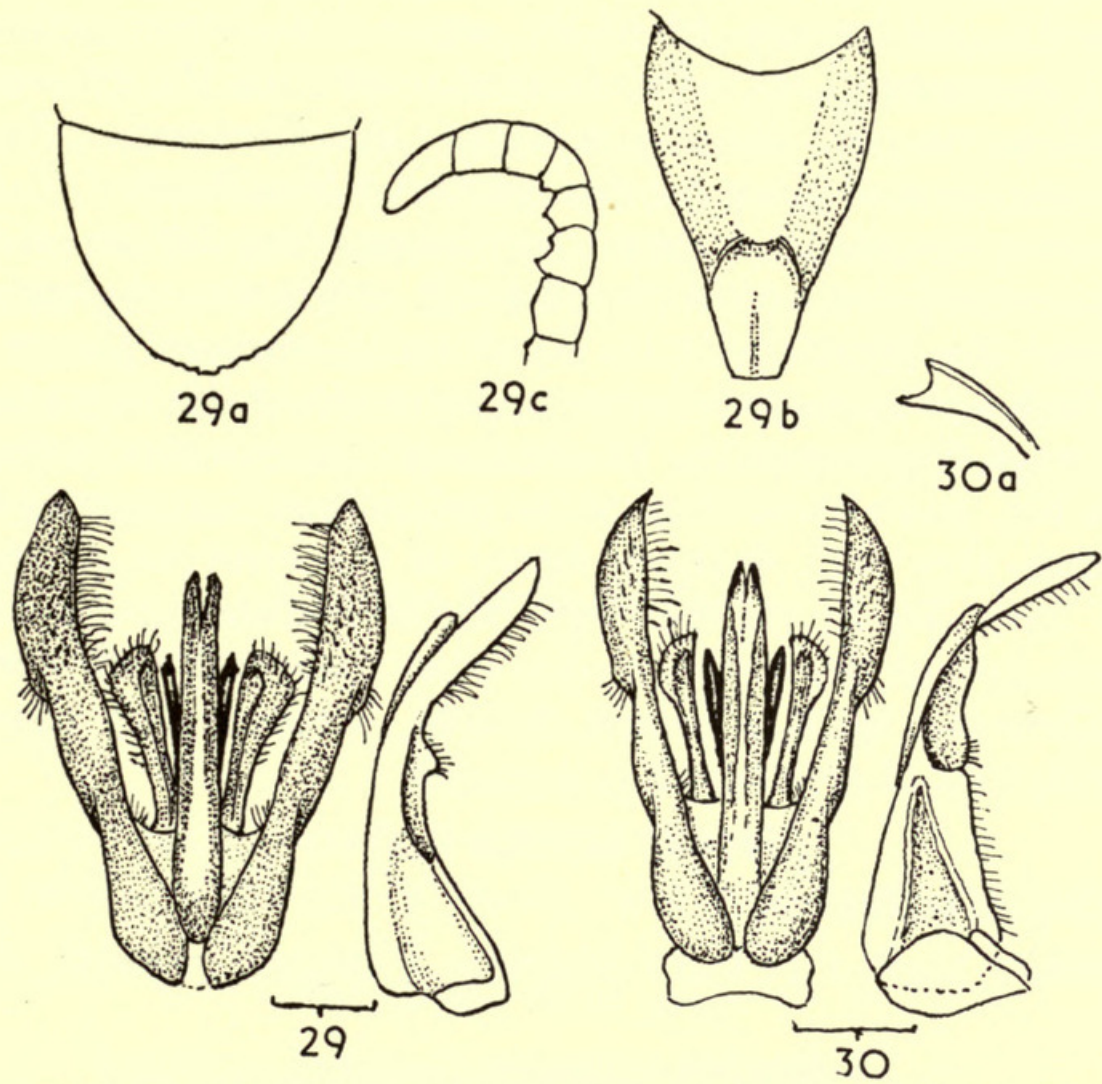

FIG. 29. Bembix guigliae ડే, genitalia, $\times$ I5. Fig. 29a. Bembix guigliae ${ }^{\star}$, apical tergite, $\times \mathrm{I}_{5}$. FIG. 29b. Bembix guigliae $\widehat{\delta}, 7$ th sternite, $\times$ I5. FIG. 29c. Bembix guigliae $\widehat{\sigma}$, apical joints of flagellum, $\times$ I5. FIG. 30. Bembix fuscipennis ${ }^{\star}$, genitalia, $\times 20$. FIG. 30a. Lateral view of apex of inner paramera.

three or four spots, flavo-ferruginous, the black maculae on the underside of the femora larger than in the $\sigma^{*}$, otherwise like the $\sigma^{*}$ in colour, sculpture, and pilosity.

Second joint of the flagellum four times longer than wide and twice as long as the third. Inner orbits feebly divergent below. Clypeus twice as wide as long.

Labadi and Accra, Gold Coast, March-May, 9 춯 Kaffrine, Senegal, August, I 후; Labadi and Accra, April and August, 6 우; Kaffrine, Senegal, I + ; Tillembeya, River Niger, August, I 0 .

Named after Dottoressa Delfa Guiglia of the Genoa Museum who has published valuable papers on the African Sphecidae.

Closely related to B. fuscipennis, but with a different colour-pattern and sufficiently different genitalia. The outer paramera are wider than in fuscipennis i. sp. and much more densely pilose on the underside. In this species and in fuscipennis the inner paramera in the normal position and viewed from above have the appearance 
of cylindrical rods. They are actually rod-shaped basad, but are expanded and spatulate apically, with the anterior margin strongly concave.

On account of the yellow fasciae and maculae on the thorax this is not the $B$. stevensoni Parker. I take this opportunity to reply to some criticisms by Professor Parker (I942, Proc. Ent. Wash. 44: 208). In my monograph of the African Sphecidae (I93I, Ann. Transv. Mus., 14: 2I4) I stated that stevensoni was only a clear-winged variety of fuscipennis. I have a fairly large series before me, taken in many cases in the same localities and at the same times as the typical form. Professor Parker, in the paper referred to, contrasts in Pl. I8 the shape of the outer paramera with those of a specimen of fuscipennis i. sp. which he received from a Mr. Stevenson and stated to be determined by myself. He also says that this illustration, Fig. I5, is 'in all essentials identical with that given for this species by Handlirsch'. In view of the fact that labels are often misplaced, I accept no responsibility for determinations which do not carry my printed determination label and which are not obtained direct from me. Furthermore, the illustrations in Handlirsch's monograph are by no means reliable, being limited in most cases to the upper ramus of the stipes and so devoid of detail as to be semi-diagrammatic. His figure for fuscipennis is inaccurate, and I therefore give in Fig. 30 an illustration of the genitalia of that species. It will be seen that, on comparing this with Parker's figure of the genitalia of stevensoni (I929, Proc. U.S. Nat. Mus. "5, Pl. I4, fig. I97), the only difference, a very slight one, is that the apical part of the stipes on this inner margin is very obtusely angular, whereas in fuscipennis i. sp. it is almost straight. Parker's Fig. I99 of the seventh tergite agrees with that of fuscipennis.

\section{Bembix agrestis Parker}

1929, Proc. U.S. Nat. Mus. 75: 135.

Dessie, November I945, I ðే; Lake Bishoftu, Ethiopia, 7,000 ft., February I948, 2 우오.

\section{Bembix massaica Cameron}

I910, Sjöstedt's Kilimandjaro-Meru Exped. 8: 290.

River Hawash, S. of Adama, Ethiopia, June I946, I2 우․

1845, Hymen. Eur. 1: 491.

\section{Bembix intermedia Dahlbom}

Danakil, Mille River, I,500 ft., Ethiopia, July I946, I 9.

Smaller than South African specimens, I2 mm. long.

\section{Bembix cultrifera ypsilon subsp. $n$.}

\section{B. cultrifera Arnold 1929, Ann. Transv. Mus. 13: 339.}

ㅇ. $\mathrm{I} 6 \mathrm{~mm}$. long. Disk of mesonotum with $\mathrm{U}$-shaped yellow macula, the base touching the hind margin but the arms not reaching the anterior margin. The labrum is even shorter than in the type of the species, being but little longer than wide at the base. The flagellum is thinner, the second joint fully four times longer than wide, instead of three and a half. Wings short, the forewing not extending back beyond the apex of the fourth tergite.

Ufdem, Ethiopia, August I945, I ㅇ. 


\section{Subfamily Ampulicinae}

Dolichurus ignitus contractus subsp. $\mathrm{n}$.

D. ignitus Smith I869, Trans. Ent. Soc. Lond.: 304.

ㅇ. 8.5-Io mm. long. This race differs from ignitus i. sp. as follows. Apex of the clypeus, mandibles, tibiae, and tarsi blackish-brown. Last three abdominal segments and apical margin of the third fusco-ferruginous.

Face with faint traces of rugae at the sides, otherwise smooth, and, like the vertex, with a few very shallow punctures. The dorsum of the pronotum is more narrowed cephalad and less depressed in the middle, so that the posterior tubercles are less prominent, the transverse rugae on the anterior margin are reduced to faint striae, and the shoulders are distinctly dentiform and not merely rectangular. The dorsum of the epinotum is much more narrowed caudad, the base being three-fifths wider than the apical margin, whereas in ignitus i. sp. it is only one-seventh wider. The rugosity on the epinotal dorsum is much reduced, the transverse rugae being fewer. In the larger specimen (type) the hind margin is raised at the corners into blunt triangular teeth, but on the smaller specimen the margin is only slightly higher there.

Dilla (Sidamo), Ethiopia, April, 2 웅․

\section{Ampulex toroensis Turner}

1919, Ann. Mag. Nat. Hist. 4: (9) 45.

Adis Ababa, I or. $^{\circ}$

Ampulex sp.

Accra, Gold Coast, December I94I, I ot.

Possibly the $\sigma^{*}$ of one of the several species of Kohl described only from 우오.

Subfamily SpHEcinaE

Sceliphron (Pelopeus) fulvo-hirtum Arnold

1928, Ann. Transv. Mus. 12: 246.

Lekempti, Ethiopia, May I946, 4 §ోో.

Sceliphron (Hemichalybion) brachystylus Kohl

1888, Verh. Zool. bot. Ges. Wien, 38: I54 ㅇ.

1918, Ann. naturh. Hofmus. Wien, 32: 83 ot.

Lake Bishoftu, Ethiopia, May I946, I o.

Sceliphron (Chalybion) planatum sp. n.

(FIG. 3I)

đ. I4 mm. long. Metallic blue, the abdomen steel blue, femora and tibiae purplishblue, tarsi dark brown. Antennae black. Mandibles fusco-ferruginous. Wings hyaline, the apex beyond the cells narrowly fuscous. Clypeus and face with long silvery pubescence. The rest of the head and the thorax with outstanding, long, and whitish pilosity. The abdomen with adpressed greyish pubescence.

Clypeus distinctly convex, subcarinate medially on the anterior half, the apical 
margin tridentate. Face shining, fairly strongly, but sparsely punctured, the vertex shining with a few punctures, the temples impunctate. Thorax shining, the promesonotum very sparsely punctured, a little more finely than the face, the pronotum bituberculate. Mesopleura and mesonotum with very shallow, widely spaced punctures which, seen at a certain angle, form vertical lines. Metapleura not sunken, the surface on the same plane as the mesopleura and sides of the epinotum, with which they are so completely fused that the margins are almost obliterated; they are finely,

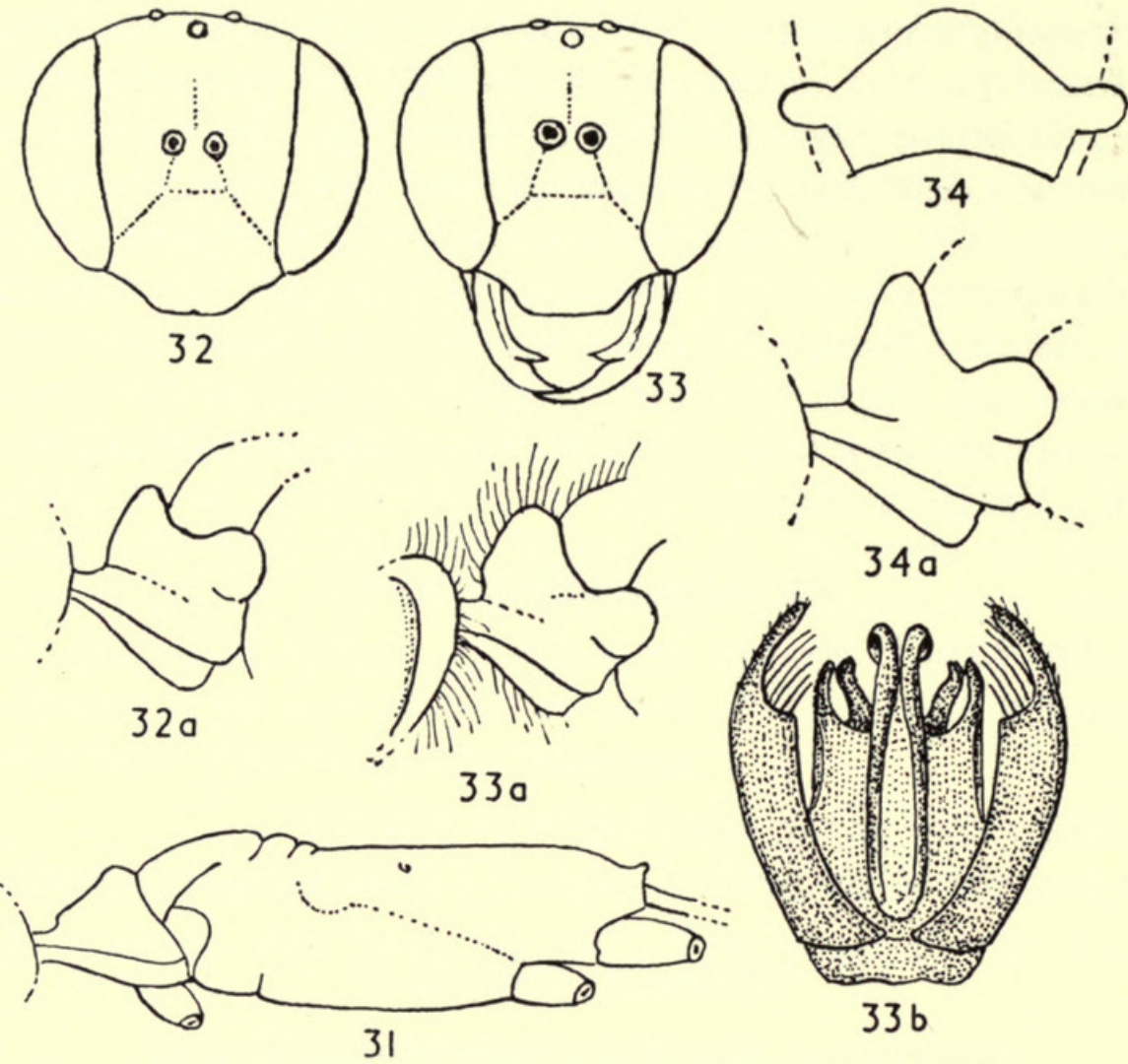

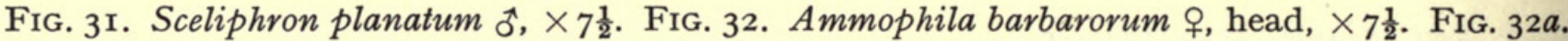
Ammophila barbarorum + , pronotum, $\times 7 \frac{1}{2}$. FIG. 33. Ammophila caprella ${ }^{7}$, head, $\times 7 \frac{1}{2}$. FIG. $33 a$. Ammophila caprella $\delta$, pronotum, $\times 7 \frac{1}{2}$. FIg. 33 . Ammophila caprella $\delta$, genitalia, $\times 18$. FIGs. 34 and 34a. Ammophila argyrocephala +, pronotum, front and side views, $\times 12$.

shallowly, and sparsely punctured. Seen from the side, the outline of the mesopleura is almost a straight line, as in S. heinii Kohl.

Epinotum very long, transversely striate, the dorsum three times longer than the only slightly lower declivity. The dorsum is almost flat, not grooved down the middle. Petiole moderately curved, as long as six-sevenths of the hind metatarsus. Interocular distance on the vertex equal to the length of the second joint of the flagellum plus three-fourths of the third, and hardly greater than across the clypeus. Second joint of the flagellum barely longer than the third, and not quite three and a half times longer than wide at the apex. Third abscissa of the radius one-fifth longer than the second.

Danakil, Mille River, I,500 ft., Ethiopia, July I946, 2 추․

This species belongs to the section of Chalybion in which the metapleura are not sunken, and is not to be confused with $S$. heinii Kohl in which they are distinctly so. 
Ammophila (Podalonia) tydei Le Guillou v. capensis Le Peletier

1845, Hist. Nat. Ins. Hymén, 3: 368.

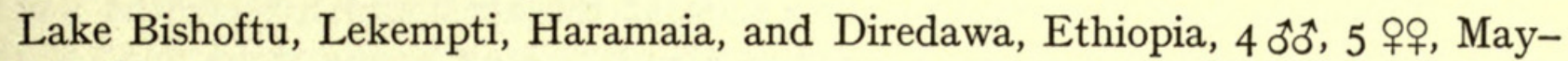
September.

\section{Ammophila gracillima Taschenburg}

I869, Z. ges. Naturgesch. 34: 433 .

Sardo, Ethiopia, July I946, I ô. $^{\text {. }}$

Ammophila beniniensis Palisot de Beauvois

1837, Ins. rec. en Afr. et Amér.: 48.

Moggio, Ethiopia, April I948, I $\sigma^{\star}$.

Ammophila bonae-spei Le Peletier v. ferrugineipes Le Peletier

1845, Hist. Nat. Ins. Hymén. 3: 383 .

Dilla, Ethiopia; Accra and Labadi, Gold Coast; Kaffrine, Senegal: 3 ๙ోఓ, 5 웅․

\section{Ammophila punctaticeps Arnold}

1919, Proc. Rhod. Sci. Ass. 18: 52.

Tillembeya, River Niger, French Sudan, September I948, I q.

Ammophila barbarorum sp. $\mathrm{n}$.

(FIGS. 32, 32a)

ㅇ. 2I mm. long. Black. Mandibles excepting the apex, tegulae, the apex of the first tergite above and the whole of the underside, the second tergite and sternite, and the sides of the third tergite ferruginous. Legs ferruginous, excepting the upper side of the fore and middle tibiae and the hind coxae, trochanters, and femora, which are black. The metatarsus of the hind legs and the underside of the scapes fuscoferruginous. Wings hyaline, slightly tinged with yellow, the apex of the forewing faintly fuscous, the veins brown.

Clypeus, lower half of the face, and the temples with a greyish silvery pubescence, and a long whitish pilosity. Thorax, including the trochanters and the anterior femora, with a similar pilosity, and on the pleura, mesonotum, and sides of the epinotum a yellowish-grey tomentum which does not obscure the sculpture. Head dull, face and clypeus finely and shallowly punctured, the interspaces almost twice as wide as the punctures on the clypeus, upper half of face, and vertex, and about as wide on the lower half of the face. Temples almost impunctate.

Pronotum finely punctured, the dorsum slightly shining. Mesonotum transversely striate, closely punctured between the striae, the sculpture less strong in the middle posteriorly. Scutellum and metanotum closely and longitudinally striate. The pleura finely punctured, less closely than the mesonotum, and with traces of transverse striae on the sterna. Scutate area of the epinotum closely, arcuately, transversely striate, widest across the middle, one-fourth longer than wide at the base. Clypeus feebly convex, two-thirds wider than long, the apical margin convex. Inner orbits 
barely convergent below. Interocular distance on the vertex equal to the length of the first joints of the flagellum plus one-fourth of the fourth joint. Second joint of the flagellum four times longer than wide at the apex and five-eighths longer than the third. Dorsum of the pronotum about as long as the third joint of the flagellum, very slightly depressed on each side of the middle, but much less widely so than in dolichocephala Cameron, three times wider behind than long in the middle, the anterior face nearly vertical, not oblique as in dolichocephala Cameron. First joint of the petiole as long as the second, the second tergite conical, nearly twice as long as wide behind. Fifth to sixth tergites with a decumbent and silvery pubescence. The third abscissa of the radius in the type is only one-third as long as the second, and in the paratype even less, so that the second and third transverse cubital veins are almost contiguous on the radius. In the paratype the pronotum is a little shorter than in the type and very feebly depressed on each side of the middle.

Adis Ababa, November 1945, 2 우.

Related to dolichocephala Cameron, from which it may be distinguished by the slope of the pronotum, the much less produced clypeus, and the shorter joints of the flagellum. In dolichocephala the second joint of the flagellum is fully five times longer than wide, and the interocular distance on the vertex is equal to the length of the first two joints of the flagellum plus half of the third.

\section{Ammophila caprella sp. $n$.}

(FIGs. 33, 33a, and 33b)

๙. $23 \mathrm{~mm}$. long. Black. Mandibles excepting the apex, the fore legs, the underside of the middle femora, and the middle and hind tibiae ferruginous; the underside of the hind tibiae blackish in the apical half. The underside of the first tergite (second joint of the petiole), the second tergite and sternite, and the sides of the third tergite fusco-ferruginous. Wings hyaline, the apex faintly fuscous, the veins dark brown.

Face and clypeus with a dense, dull golden yellow pubescence, the temples with silvery pubescence. Head and thorax with an abundant yellowish-grey pilosity, fairly short on the mesothorax and epinotum, long elsewhere. Below the pilosity is a dense, pale yellowish tomentum, obscuring the sculpture except on the dorsum of the thorax. Upper part of the face and the vertex dull, shallowly punctured, closely on the face, with a small area in front of the ocelli impunctate. Thorax dull, the pronotum finely and sparsely punctured, the mesonotum closely punctured and finely transversely striate. Scutellum and metanotum punctured and with a trace of longitudinal striae. Scutate area of the epinotum closely transversely rugose and punctured between the rugae.

Clypeus flat, more than one-third of its length projects beyond the level of the bottom of the eyes, the anterior margin straight. Interocular distance on the vertex equal to the length of the first three joints of the flagellum, and one-fourth greater than interocular distance across the clypeus.

Second joint of the flagellum nearly four times longer than wide and about onethird longer than the third joint. Posterior ocelli nearly twice as far from the eyes as from each other. Pronotal collar very convex transversely and lengthwise, three 
times wider behind than long in the middle. Scutate area of the epinotum almost parallel-sided, one-fourth longer than wide. First joint of the petiole a little longer than the second. Second tergite three-fourths longer than wide at the apex.

ㅇ. $24 \mathrm{~mm}$. long. Pilosity on the head and thorax not so dense as in the $\sigma^{*}$. Clypeus less produced than in the $\delta$, three-fourths wider than long, the anterior margin feebly convex, and of the same shape as in barbarorum ․

Posterior ocelli two-thirds farther from the eyes than from each other. Interocular distance on the vertex equal to the length of the first three joints of the flagellum plus one-third of the fourth. Second joint of the flagellum nearly twice as long as the third. Scutate area of the epinotum widened caudad, one-sixth longer than wide. Otherwise like the $\hat{\sigma}$.

Adis Ababa, April I948, I đ*; Managasha, Ethiopia, November I945, I ㅇ.

Related distantly to $A$. insignis Smith, race transvaalensis Cameron, from which it differs by the long pilosity and colour of the pubescence on the face, and in the $\sigma^{t}$ by the clypeus being wider and flat in the apical part, and in both sexes by the much shorter joints of the petiole. The shape of the clypeus in the $q$ also differs considerably from that of insignis.

\section{Ammophila argyrocephala sp. n.}

(FIGS. 34 and 34a)

ㅇ. I9-2I mm. long. Black. Basal half of the mandibles, tegulae, the underside of the petiole, second and third tergites at the base and sides, and the second and third sternites, ferruginous. Legs dark ferruginous, the upper side of the coxae, trochanters, and femora more or less black. Wings hyaline.

Clypeus, face, and temples with a dense silvery pubescence, which on the face appears to end abruptly below the vertex, where the pubescence is much shorter. The temples have in the middle a fringe consisting of a single row of long, white hairs. Thorax with a yellowish-silvery and dense tomentum, obscuring the sculpture on the pleura and epinotum. Pronotum smooth, almost impunctate. Mesonotum indistinctly transversely striate, the striae absent from the disk. Epinotal dorsum closely transversely rugulose.

Clypeus five-sixths wider than long, the apical margin feebly convex. Inner orbits parallel. Interocular distance on the vertex equal to the length of the first two joints of the flagellum plus three-fourths of the third.

Second joint of the flagellum four and a half times longer than wide and fully half as long again as the third. Posterior ocelli nearly one and a half times farther from the eyes as from each other. Pronotal collar four times wider behind as long, the dorsal face merging gradually into the sloping anterior face; seen from the front it is much narrowed dorsad, or broadly triangular with the apex rounded. The pro-pleura have a single row of long hairs. Scutate area of the epinotal dorsum gradually widened from the base to near the apex, then narrowed, one-third longer than wide at the base. First joint of the petiole a trifle longer than the second. Second abscissa of the radius twice as long as the third.

River Errer, May I948, I 우 Meisso, Ethiopia, September I945, 2 우․

ENTOM. 2. 3 
Sphex (Parasphex) senegalensis sp. n.

(FIG. 35)

๙. I3 mm. long. Black. This species is so much like S. lividocinctus Costa, a north Mediterranean species, that one would be inclined to consider it a subspecies but for the fact that the habitats are separated by the Mediterranean Sea and the Sahara. Kohl's description of Costa's species (I890, Ann. naturh. Hofmus. Wien, 5:339,
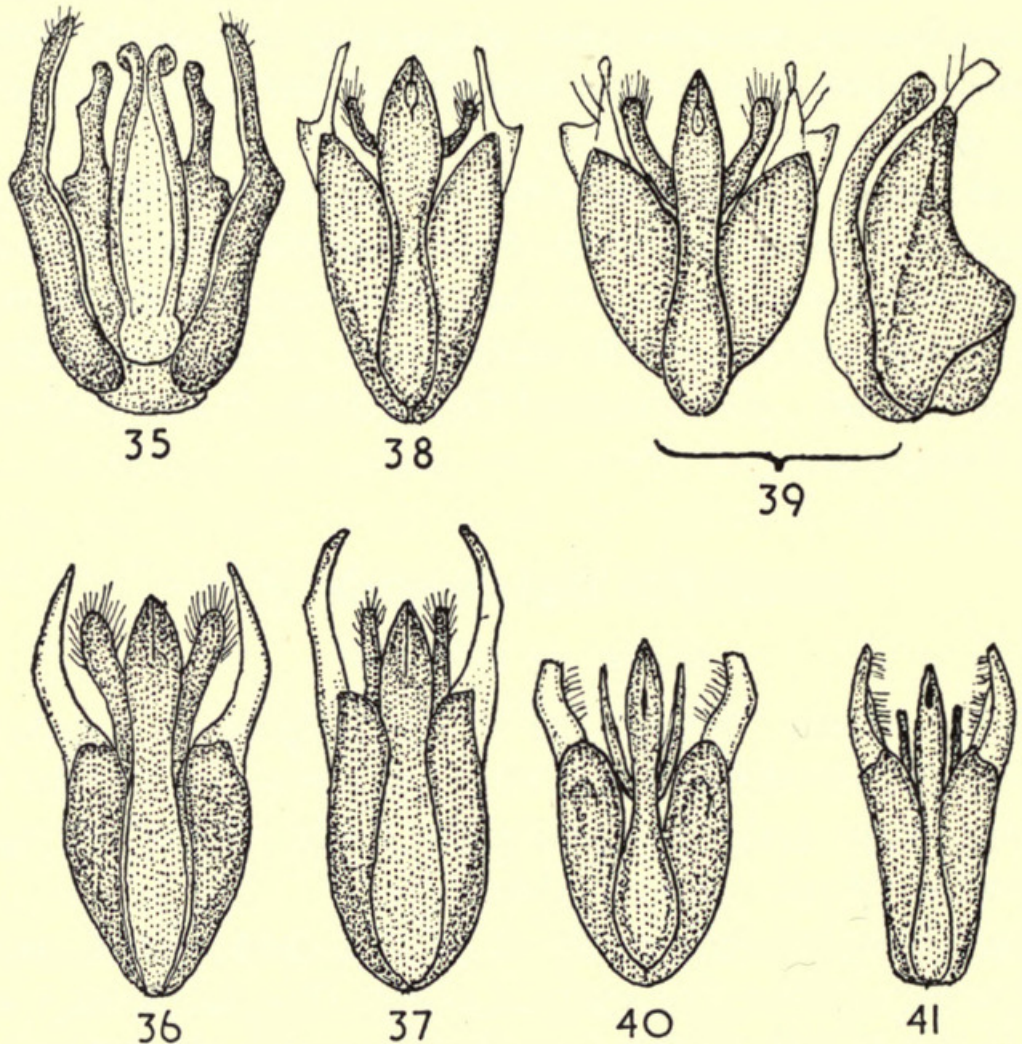

FIG. 35. Sphex senegalensis, genitalia, $\times 2$ I. FIG. 36. Tachytes basilica, genitalia, $\times$ I8. FIG. 37 . Tachytes guichardi, genitalia, $\times$ I 8 . FIG. 38. Tachytes habilis, genitalia, $\times 18$. FIG. 39. Tachytes lamentabilis, genitalia, $\times$ I8. FIG. 40. Tachytes griseola, genitalia, $\times 2$ I. FIG. 4I. Tachytes rufitibialis, genitalia, $\times 2 \mathrm{I}$.

Pl. VIII, fig. II) applies in nearly every respect to this species except in the following details:

First tergite dark brown, the apical margin of the second to fifth tergites reddish testaceous.

Head and thorax with a long yellowish-white pilosity which on the face, temples, and epinotum is so dense as to hide the underlying sculpture. First tergite with a thin decumbent pubescence of the same colour.

Vertex shining, finely and sparsely punctured. Mesonotum shining, punctured, the interspaces for the greater part two or three times wider than the punctures. Scutellum shining with a few small punctures and distinctly grooved down the middle. Mesopleura closely punctured, the punctures larger than those of the mesonotum. Epinotum closely, transversely, and somewhat arculately rugose, on the dorsum posteriorly also punctate. The proportions of the antennal segments, the interocular 
distance on the vertex, and the length of the petiole are the same as in lividocinctus Costa, also the venation. Claws with four distinct teeth.

Koalack, Senegal, August I943, I ô.

\section{Sphex (Isodontia) Simoni du Buysson}

1897, Ann. Soc. Ent. Fr. 356.

Dilla, Ethiopia, April I948, I 우.

Sphex (Proterosphex) cinerascens Dahlbom

I845, Hym. Eur. 1: 25 and 436.

Labadi, Gold Coast, and Tillembeya, River Niger, French Sudan, April and September, 5 ठैరే 5 우우.

Sphex (Proterosphex) incomptus Gerstaecker

1871, Arch. Naturgesch. 37: 352.

Aburi, Gold Coast, Dec. I94I, 2 우; Dilla, April I948, and River Hawash, Ethiopia, June 1946, 2 우․

\section{Sphex (Proterosphex) nigrohirtus Kohl}

I895, Ann. Naturh. Hofmus. Wien, 10: 66.

S. convadti Berland, 1927, Bull. Mus. Hist. Nat., Paris, 1927 (2) : 154.

Aburi, Gold Coast, December I94I, I 9 .

This specimen agrees in every detail with the description of conradti. An examination of the material in the National Museum, Southern Rhodesia, comprising two 우 from Abak, Nigeria, and two 우 from Uganda, shows that the depth of the depression on the clypeus varies, and conradti are merely specimens in which it is deep.

Sphex (Proterosphex) haemorrhoidalis Fabricius

I781, Spec. Insect. 1: 443 .

This species is given to considerable variation in the colour of the flagellum, clypeus, and legs, all of which may be more or less red instead of black as in the typical form. Four $\widehat{\delta}^{\widehat{0}}$ from Aburi, Gold Coast, and Jowaha and River Didessa, Ethiopia, do not diverge from the type, but one $q$ from Aburi has the hind tibiae fusco-ferruginous. Two other 우 from Aburi and Kpeve, Gold Coast, are intermediate between the varieties volubilis Kohl and pulchripennis Mocsárz.

\section{Sphex (Proterosphex) rufiscutis laevigatus subsp. $\mathrm{n}$.}

S. rufiscutis Turner, I918, Ann. Mag. Nat. Hist. (9) 1: 359.

․ I9 $\mathrm{mm}$. long. This differs from the typical form as follows. The epinotum has a thin, short, and greyish pilosity, very scanty on the dorsum, and the declivity lacks the decumbent pubescence which, with the pilosity, obscures the sculpture in the type. The sculpture of the dorsum consists of a very close and fine transverse striation only, larger rugae being absent; and is less narrowly caudad. There is a shallow median longitudinal impressed line. The interocular distance on the vertex is greater, being very nearly equal to the length of the first three joints of the flagellum.

The petiole is shorter, being only a little longer than the second joint of the flagellum 
(in the type of the species equal to the length of the second plus half of the third). The pronotal collar is shorter and flatter.

Near Sofara, French Sudan, September I944, I 9 .

Possibly a distinct species, but in the absence of the $\sigma^{-1}$ it is best to treat it as a subspecies.

\title{
Subfamily LARRINAE \\ Genus Tachytes Panzer
}

The collection contains a number of species of which a large proportion are represented by only one sex, and by specimens which are defective, for which reason they cannot be described although apparently new species. In all the collections which I have seen, the males outnumber the females. The reason is that the former are, by their habits, much more conspicuous. They visit flowers far more frequently than the females, and when not so occupied are in the habit of sunning themselves in a particular spot to which they return again and again if disturbed. The females make their burrows more often in hard soil, such as, for example, native foot-paths, than in loose sand. I cannot recall ever having found them nesting in the sandbanks of rivers, which are favourite nesting-sites for Bembix. The great differences in the length of the tongue and galea amongst the species might lead one to suppose that they are oligotropic, but this supposition cannot be maintained in view of the fact that species with those organs short, medium, and long have been taken visiting the same flowering bushes, such as Combretum and Zisyphus.

\section{Tachytes observabilis Kohl}

1894, Ann. naturh. Hofmus. Wien, 9: 295.

Lake Anasa, Ethiopia, April I948, I 0 .

\section{Tachytes basilica Guérin}

1844, Icon. règne anim.: 440.

(FIG. 36)

Tillembeya, River Niger, French Sudan, September I944, I 0 .

\section{Tachytes guichardi sp. $\mathrm{n}$.}

\author{
(FIG. 37)
}

đ. I3 mm. long. Black. Abdomen flavo-ferruginous, the anterior face of the first tergite and the greater part of the middle of the first three sternites blackish. Tibiae and tarsi pale reddish-brown. Wings hyaline, slightly yellow, the apex beyond the cells pale brown. Head, thorax, and base of first tergite with yellowish pilosity. Tergites with a pale yellow decumbent pubescence arranged in a chequered pattern as in the basilica group. Vertex, mesonotum, and scutellum very finely punctured, the interspaces barely larger than the punctures. Epinotum and mesopleura very finely reticulate-punctate. Sternites moderately shining, very finely and closely punctured.

Galea more than two and a half times longer than the scapes. Second joint of the 
flagellum three times longer than wide, the three to six joints moderately arcuate below.

Interocular distance on the vertex a little shorter than the second joint of the flagellum. Dorsum of the epinotum about one and a half times wider at the base than long. Seventh tergite trapezoidal, the apical margin wide and feebly convex. Basal joint of anterior tarsi with five to six spines. The outer paramera of the genitalia densely villose below, the membranous apical portion narrow and very long.

Dakar, Senegal, August I943, I ot.

Allied to neavei Turner from which it differs by the wider vertex and the flavoferruginous abdomen. In the colour of the abdomen it resembles basilica Guérin, which, however, is a larger insect with a shorter galea.

\section{Tachytes dilaticornis Turner}

1917, Ann. Mag. Nat. Hist. (8) 20: 23.

Jowaha, N. of Debra Sina, 6,00o ft., Ethiopia, August I946, I o

Loc. cit., supra: $\mathbf{1} 7$.

\section{Tachytes hamiltoni Turner?}

ㅇ. $15 \mathrm{~mm}$. long. This is probably the hitherto undescribed of of this species. The pilosity and pubescence of the head and thorax is brassy golden. The femora, excepting the basal half of the middle pair, are flavo-ferruginous. First four tergites with apical fasciae of silvery pubescence, the fifth and the sides of the fourth with a preapical row of long, porrect, and brown setae, the pygidial area with dark coppery pubescence. Second sternite over the basal two-thirds dull and microscopically, closely punctured, the apical third, like the following sternites, smooth, shining, and with a few large setigerous punctures. Interocular distance on the vertex very little shorter than the second joint of the flagellum, the latter three times longer than wide. Galea as in the $\sigma^{t}$, twice as long as the scapes. Basal joints of the anterior tarsi with six spines on the outer margin, the pubescence on the middle and hind tibiae golden.

Accra, Gold Coast, July I946, I 9 .

The type of the species, a $\sigma^{*}$, was taken in British East Africa, so this $q$ may perhaps be a distinct species, but the main characters suggest that the identification is correct.

\section{Tachytes habilis Turner}

(FIG. 38)

Loc. cit., supra: 35 .

Koundé-Saré, French Sudan, August I945, 4 đ̋ .

The locality of the type of the species is near Fort Johnstone, Nyasaland.

Loc. cit., supra: 34 .

\section{Tachytes versatilis Turner}

Moggio, Ethiopia, April I948, I $\sigma^{\star}$. 
Loc. cit., supra: 32 .

\section{Tachytes neglecta Turner}

Tillembeya, River Niger, French Sudan, September I944, I o.

The genitalia resemble those of habilis Turner, but the apical portion of the outer paramera are dilated, or spoon-shaped, and not parallel-sided as in that species.

\section{Tachytes lamentabilis sp. $\mathrm{n}$.}

(FIG. 39)

o. I4 mm. long. Black. Face and clypeus with pale golden pubescence and pilosity. The rest of the head, the thorax, and base of first tergite with dull yellow pilosity, short on the mesonotum. First four tergites with apical fasciae of grey pubescence, sternites 2-4 with narrow, thin, and yellowish-grey apical fasciae, the fifth and sixth with brown fasciae. The seventh tergite closely punctured and with fulvous pubescence. Wings flavo-hyaline, without any apical infuscation, the veins brown. Vertex with a few small and shallow punctures. Dorsum of thorax closely and microscopically punctured. Second sternite shallowly and sparsely punctured in the middle, more closely and very finely at the sides, the following sternites closely and strongly punctured in the apical half, the basal half smooth and shining. Galea half as long again as the scapes. Clypeus subcarinate lengthwise in the middle. Interocular distance on the vertex equal to the length of the first two joints of the flagellum. The second joint is only twice as long as wide. Dorsum of the epinotum short, as long as the scutellum. Seventh tergite subtriangular, the apex narrowly truncate. Basal joints of the anterior tarsi with six spines.

․ I6 mm. Clypeus very convex lengthwise, but not subcarinate. Galea as long as the scape. Interocular distance on the vertex equal to a little more than the length of the second joint of the flagellum. The latter nearly three times longer than wide. Otherwise like the $\mathrm{o}$.

Aburi, Gold Coast, December I94I, I ô, I ㅇ.

Owing to the scanty pilosity and pubescence this species looks very different from the other species of the genus. To the naked eye, it looks more like some of the larger species of Liris (Motes) of the sepulchralis group.

\section{Tachytes compacta sp. n.}

9. I2-I4 mm. long. Black. First tergite at the sides and on the apical margin, the apical margin of the second tergite, the base of the second sternite, and apical margin of the third sternite, somewhat reddish.

Clypeus, face, temples, and the thorax with a dense, pale brassy pubescence, that of the thorax paler or almost silvery, and very dense on the pleura. The long erect pilosity present in most species of the genus is absent. First four tergites and sternites with apical faciae of yellowish-grey pubescence, the pygidial area with a dense, fine, and golden pubescence.

Extreme apex of the hind femora and the basal third of the hind tibiae with pale golden pubescence, the apical two-thirds with silvery pubescence. Wings short, hyaline, the veins ochreous. Puncturation of the vertex and thorax and second 
sternite close and microscopic, the second sternite dull except on the apical margin, the third to fifth sternites shining and very sparsely punctured, but with the apical fourth dull and finely punctured, the sixth shining, sparsely and fairly coarsely punctured. Galea shorter than the scape. Apical margin of the clypeus narrowly reflected. Interocular distance on the vertex equal to the length of the second joint of the flagellum plus half of the first. Epinotal dorsum as long as the scutellum. Basal joint of the anterior tarsi with six yellow spines on the outer margin.

Kaffrine, Senegal, August I943, 2 우.

Closely related to T. erynnis Turner, from which it differs by the colour of the pubescence, the absence of pilosity, the colour of the first two abdominal segments, and the shining third sternite. The smaller specimen has the first two tergites paler, or yellowish-red.

\section{Tachytes fucata sp. $\mathrm{n}$.}

ㅇ. I5 mm. long. Head and thorax black, abdomen ferruginous, the base of the third and fourth tergites, the whole of the fifth, black. The middle and apical margin of the fourth and fifth sternites and the whole of the sixth blackish. Legs ferruginous, the upper side of the fore and middle femora blackish, the posterior coxae and trochanters fusco-ferruginous. Wings clear hyaline, the veins ochreous. Pubescence on the head and thorax dense, yellowish-silvery, on the pleura and sterna silvery, the face and epinotum also with a short, exserted whitish pilosity. First four tergites with apical fasciae of silvery pubescence. Sternites shining, the puncturation microscopic. The pygidium elongate triangular, four-fifths longer than wide at the base, clothed with dark golden pubescence.

Galea half as long as the scape. Interocular distance on the vertex equal to very little more than the length of the second joint of the flagellum; the second joint two and one-third times longer than wide at the apex. The erect pilosity on the dorsum of the epinotum is confined to the sides, which gives a false impression of that part having a median triangular field. Basal joint of the anterior tarsi with five spines on the outer margin.

Aleg, S. Mauritania, September I943, I 9 ; Tillembeya, River Niger, French Sudan, August I944, I ㅇ.

Possibly related to $T$. sjöstedti Cameron, but that species has only the three basal abdominal segments red, and the abdomen much broader at the base, or conical, whereas in this species it is lanceolate. The specimen from Tillembeya has the wings slightly tinged with yellow, and the third and fourth abdominal segments less stained with black.

\section{Tachytes griseola sp. $\mathrm{n}$.}

(FIG. 40)

6. $7 \cdot 5-8 \cdot 5 \mathrm{~mm}$. long. Black. Tarsi brownish-ochreous, the apical joint paler. Sixth to ninth joints of the flagellum red below. Wings hyaline, the veins and the tegulae pale ochreous. Clypeus and face with a silvery pubescence and a scanty grey pilosity. Thorax with a sparse decumbent pubescence and a long, white pilosity, longest on the sides of the thorax and epinotum. The anterior and middle femora also 
with the same and dense pilosity. Abdomen with a fairly long, adpressed greyish pubescence, directed inwards on the basal half of the tergites and outwards on the apical half, where it is denser and forms transverse fasciae. Seventh tergite with silvery pubescence. Vertex, mesonotum, and scutellum very finely and closely punctured (30 diameters), the dorsum of the epinotum closely and somewhat obliquely rugulose-recticulate (I6 diameters). The declivity dull, closely and transversely striolate. Sternites shining, the second closely and finely punctured, the following segments more coarsely and less closely.

Galea shorter than the scape. Vertex wide, the interocular distance at the base of the eyes being only two and a half times greater than on the vertex, where it is equal to very little more than the length of the first two joints of the flagellum. The second joint of the flagellum is short, being not quite twice as long as wide at the apex.

Dorsum of the epinotum as long as the scutellum and metanotum united. Basal joint of the anterior tarsi with three spines on the outer margin.

ㅇ. Io $\mathrm{mm}$. long. The extreme apical margins of the first five abdominal segments fusco-ferruginous. Pygidial area clothed with a dark golden pubescence. Second sternite fairly dull, closely and microscopically punctured. Interocular distance on the vertex equal to the length of the first two joints of the flagellum. Basal joint of the anterior tarsi with five white spines on the outer margin. Otherwise like the $\$$.

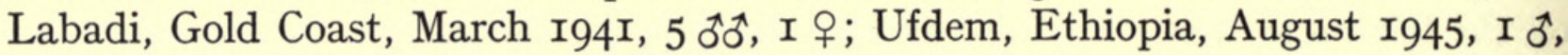
I + . These are a little larger than the specimens from the Gold Coast, + , Io mm., I 우, I0.5 mm. long.

This species and the one described below belong to a group of small Tachytes in which the tarsi are pale reddish-yellow and the vertex is wide. It includes $T$. lepida Arnold, $T$. nigroannulata Bischoff, and $T$. silverlocki Turner, from all of which it differs by the genitalia.

\section{Tachytes rufitibialis sp. $\mathrm{n}$.}

(FIG. 4I)

o, 7.5-9 mm. long. Closely related to preceding species, $T$. griseola, from which it differs as follows. Third to ninth joints of the flagellum dark brown above, reddishyellow below. Apices of the femora and the tibiae reddish-yellow, like the tarsi. Pubescence on the clypeus and face pale golden. Pubescence and pilosity on the thorax yellowish-grey. Tergites I-4 with yellowish-grey fasciae covering the apical third of the segments, the basal portion with only a microscopic black pubescence.

Sculpture of the epinotum like that of griseola, but stronger, the declivity moderately shining.

Interocular distance at the base of the eyes two and a third times greater than on the vertex, where it is equal to the length of the first two joints of the flagellum plus one-fourth of the third.

Pygidial area more rounded at the apex, covered with pale golden pubescence. Outer paramera of the genitalia with the apical portion more acute, not bluntly angular on the outer margin but evenly convex. Otherwise like griseola.

Tillembeya, River Niger, French Sudan, August I944, 5 రోఓో. 
Tachytes discrepans sp. $\mathrm{n}$.

(FIG. 42)

o. $9.5 \mathrm{~mm}$. long. Black. Face and clypeus with silvery pubescence. Thorax with a scanty yellowish-grey pubescence, the spinotum also with a sparse pilosity of the same colour. Wings hyaline, the veins ochreous. Tergites I-4 with apical fasciae of grey pubescence, the seventh tergite with silvery. Vertex and dorsum of the thorax very finely recticulate-punctate. Sternites not quite dull, very finely punctured, the
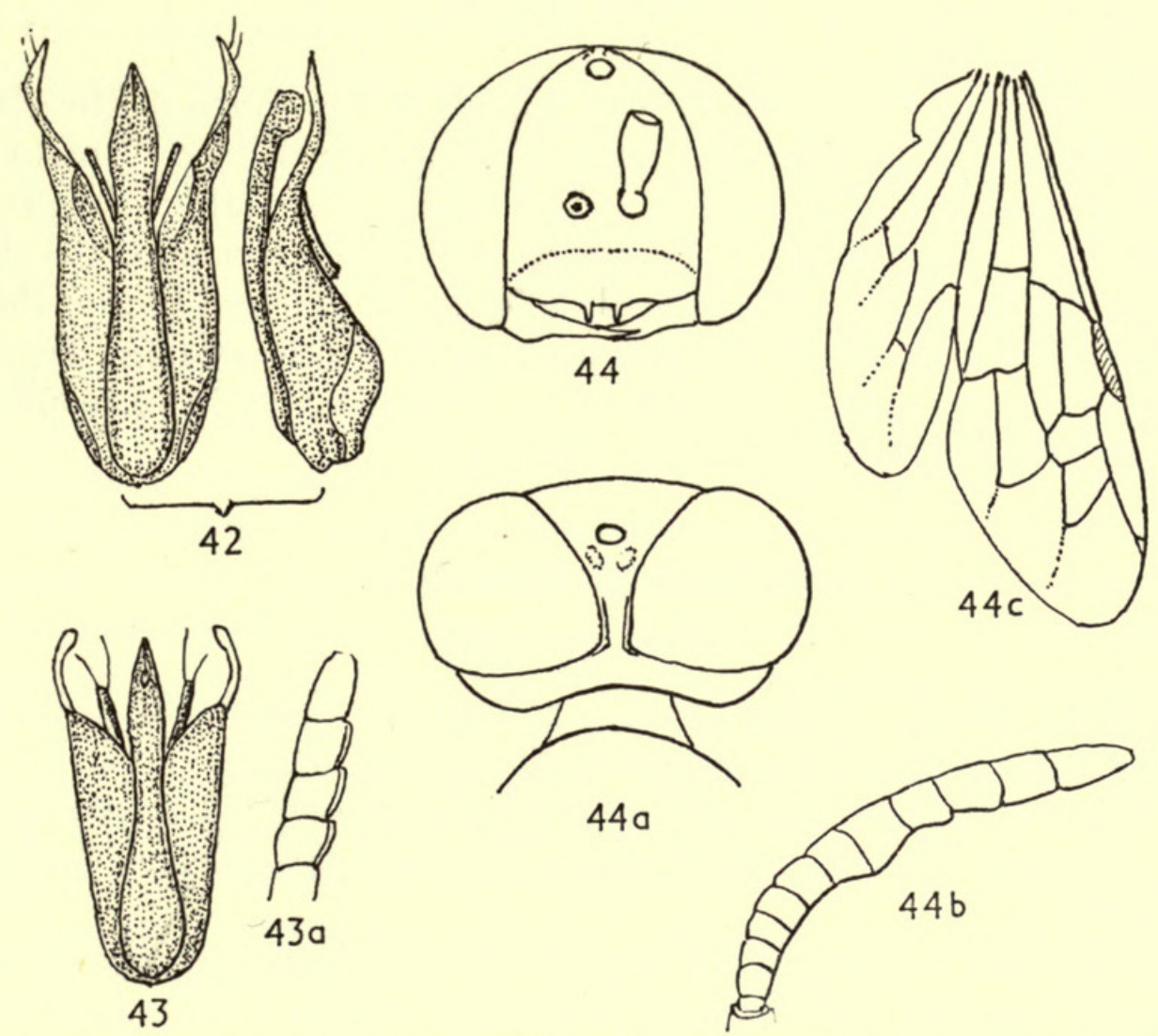

FIG. 42. Tachytes discrepans, genitalia, $\times 27$. FIG. 43. Tachytes falcigera, genitalia, $\times 18$. FIG. $43 a$. Tachytes falcigera, apical joints of the flagellum, $\times$ I 8 . FIGS. 44 and $44 a$. Odontosphex bidens $\widehat{t}$, head, $\times$ I8. FIG. $44 \vec{b}$. Odontosphex bidens 0 , flagellum, $\times 27$. FIG. $44 c$. Odontosphex bidens $\hat{0}$, wings, $\times \mathrm{I} 2$.

second, third, and fourth with a thin greyish pubescence, more abundant on the apical margins, forming fasciae. Anterior margin of the clypeus produced into a very short lobe over the median fourth. Galea shorter than the scape.

Ninth, tenth, and eleventh joints of the flagellum compressed dorso-ventrally on their inner halves and strongly carinate on the inner margin, the second joint twice as long as wide at the apex.

Interocular distance at the base of the eyes five-sevenths wider than on the vertex, where it is equal to the length of the first two joints of the flagellum. Anterior metatarsi with four white spines on the outer margin. Apical portion of the outer paramera of the genitalia very thin, lamelliform, twisted, and slightly dilated close to the apex.

ㅇ․ Io $\mathrm{mm}$. long. Tarsi, excepting the basal joint, fusco-ferruginous. Pubescence ENTOM. 2. 3 
and pilosity on the head and thorax yellowish-silvery, on the underside of the fore and middle femora silvery. Tergites I-4 with a thin greyish pubescence on the basal part, and with broad apical silvery fasciae.

Pygidial area with golden pubescence. Second sternite dull, microscopically punctured, the remaining sternites shining, fairly coarsely and very sparsely punctured. Interocular distance on the vertex slightly less than the length of the first two joints of the flagellum. The second joint of the latter two and a half times longer than wide, the ninth to eleventh joints not dilated nor carinate. Anterior margin of the clypeus without a median lobe, otherwise like the $\sigma^{t}$.

Kaolack, Senegal, August I943, I đ^, I ㅇ․

The $\sigma^{t}$ differs from all the other African species in the shape of the genitalia and, excepting instabilis and the following species, by the ninth to eleventh joints of the flagellum. The $q$ resembles $T$. silverlock $i$ Turner and $T$. disputabilis Turner, from both of which it can be distinguished by the colour of the pubescence on the sixth tergite, the sculpture of the thorax, particularly of the epinotal dorsum, and by the number of spines on the outer margin of the anterior matatarsi. From instabilis Turner $q$ it may be distinguished by its smaller size and wider vertex, which in instabilis is equal to only the length of the second joint of the flagellum.

\section{Tachytes falcigera sp. $\mathrm{n}$.}

(FIGS. 43, 43a)

๙. I4 mm. long. Black. Wings hyaline, and faintly tinged with yellow, the veins ochreous. Face and clypeus with yellowish-silvery pubescence. Thorax with a rather sparse yellowish-grey pubescence, and on the epinotum with a sparse pilosity of the same colour. Tergites I-4 with apical fasciae of silvery pubescence, the seventh with yellowish silvery.

Vertex, mesonotum, and scutellum very closely and finely punctured, the following sternites shining, sparsely and coarsely punctured. Galea a little more than half as long as the scapes. Anterior margin of the clypeus flattened.

Interocular distance at the base of the eyes twice as great as on the vertex, where it is equal to the length of the second joint of the flagellum. The second joint is two and a third times longer than wide at the apex, and the ninth to eleventh joints are compressed on their inner halves and carinate, as in the preceding species.

Dorsum of the epinotum a little shorter than the scutellum and metanotum united. Anterior metatarsi with five white spines on the outer margin. Outer paramera of the genitalia abruptly attenuated apically, the attenuated part sickle-shaped and slightly widened at the apex, the inner rod-shaped paramera emit two long and thin hairs at the apex.

Aleg, S. Mauritania, September I943, I ot.

In my key to the species (I923, Ann. Transv. Mus. 9) this runs down close to $T$. instabilis Turner, but the interocular distance is shorter than in that species. The genitalia of the specimen from Willowmore, Cape Province, which I identified as instabilis, are quite unlike those of falcigera, resembling those of $T$. bulawayoensis Bischoff. 
Tachytes seminuda sp. $n$.

ㅇ. I0.5 mm. long. Black. First two abdominal segments and the third excepting the apical margin red. Last three joints of the anterior tarsi and apical joint of the lower and hind tarsi, ferruginous. Wings hyaline, the veins pale brown. Clypeus and sides of the face and the bottom of the temples with a short and by no means dense silvery pubescence. On the thorax there is a little grey pubescence on the lateral margins of the mesonotum and on the epinotum, but the outstanding pilosity present in nearly all other species of the genus is absent.

The first three tergites have inconspicuous apical fasciae of silvery pubescence, and the pygidial area has dark golden pubescence. Vertex microscopically and closely punctured ( 30 diameters), the mesonotum closely and transversely rugulose (25 diameters), the dorsum of the epinotum reticulate-punctate and obliquely striate at the sides of the base (30 diameters). Second sternite dull, the third and following sternites shining, with a few large punctures near the apical margin. The abdomen is widest in the middle, or lanceolate, instead of being obconical or widest across the basal segment, as in the other species of the genus.

Galea less than half as long as the scapes. Eyes widely divergent below, the interocular distance at the base of the eyes being very nearly three and a half times greater than on the vertex, where it is equal to the length of the second joint of the flagellum.

Clypeus short, nearly four times wider than long. Flagellum slender, the second joint fully two and a half times longer than wide at the apex, all the following joints at least twice as long as wide. Second to fifth sternites and the fifth tergite with a row of brown setae on the apical margin. Anterior metatarsi with five yellow spines on the outer margin. Pygidial area triangular, longer than wide at the base.

Tillembeya, River Niger, French Sudan, August I944, 2 우.

This species differs from all the others known to me by the paucity of pubescence and pilosity, and the shape of the abdomen. Superficially it looks much more like a Tachysphex, e.g. T. miniatulus Arnold, than a Tachytes.

\section{Characters}

\section{PHYTOSPHEX gen. $\mathrm{n}$.}

ㅇ. Anterior tarsi without a comb, the metatarsus with a few small spines on the underside and at the apex. Hind tibiae and metatarsi with a row of long spines on the upper side. Pygidium without a marginate dorsal face.

\$. Anterior metatarsi without long spines on the outer margin, the hind tibiae and metatarsi as in the + . In both sexes the vertex is wide, the eyes not being strongly convergent above as in Tachysphex, and the sculpture of the head and thorax is strong, consisting of large and widely spaced punctures on the head and thorax, and a coarse reticulation on the epinotum. Anterior margin of the clypeus produced in the middle into an acute, wide, and triangular tooth. Otherwise like Tachysphex.

Genotype: Tachysphex turneri Arnold.

Not only does this species differ from Tachysphex in the sculpture, but the nesting habits are, according to the late Dr. Brauns's observations, totally different. Instead of burrowing in the ground, it nests in hollow stems of Aloe, Datura, \&c., and the partitions between the cells are formed of earth and little pebbles. 


\section{Phytosphex turneri Arnold}

1923, Ann. Transv. Mus. 9: 165.

A slight variety, differing from the type of the species in having the second to fourth tergites blackish in the middle and on the apical third of the segments.

Adis Ababa, Ethiopia, April I948, I ㅇ.

\section{Characters}

\section{ODONTOSPHEX gen. $\mathrm{n}$.}

๙. Mandibles not excised on the outer margin. Clypeus short, not longer than the distance between its hind margin and the antennal sockets, the anterior margin with two long and thin teeth near the middle. Eyes strongly convergent above, the vertex narrower than the anterior ocellus. Posterior ocelli oval, flattened, and almost obsolete. Second to seventh joints of the flagellum short, wider than long, the seventh and tenth swollen behind. Dorsum of the pronotum linear, lying well below the level of the mesonotum. Episternal suture absent. Dorsum of the epinotum with a defined and broad median area. Eighth sternite emarginate and bidentate. Anterior tarsi without cilia or spines. Middle tibiae with two calcaria, the inner one very small. Posterior tibiae and tarsi without long spines on the upper side, the tibiae with a row of very short spines hardly longer than the pubescence. Forewings with three cubital cells, the third less than twice as long on the cubitus as on the radius, the second receiving both recurrent veins. Hindwing: the cubitus emitted well before the end of the submedial cell.

Genotype: $O$. bidens.

The genus is remotely related to Tachysphex, from which it differs, inter alia, by the venation, the absence of the episternal suture, and the form of the flagellum.

\section{Odontosphex bidens sp. $\mathrm{n}$.}

(FIGs. 44, 44a-c)

o. $6 \mathrm{~mm}$. long. Black. Middle third of the mandibles rufescent. Flagellum ochreous, the first four joints slightly infuscated. Apical margins of the abdominal segments testaceous. Tibiae, tarsi, and the hind femora pale reddish-ochreous. Wings hyaline, tegulae and pterostigma pale yellow, the veins pale brown. Clypeus and face up to the anterior ocellus, temples, underside of the anterior femora, sides and anterior angles of the mesonotum, mesopleura, and base of the epinotal dorsum, covered with silvery pubescence. A small patch of similar pubescence on each side of the scutellar and metanotal disks.

Sides of the epinotum, and the declivity excepting the middle, with exserted and fairly dense silvery pilosity. Abdomen with a very fine, grey, and decumbent pubescence, and on the apical margins of the first five tergites fasciae of silvery pubescence. Face, from the antennal sockets to the anterior ocellus, dull, microscopically and closely punctured, slightly convex but without any swellings. Ocellar area and vertex shining, sparsely punctured. On the vertex a carinula on each side margins the eyes.

Mesonotum, scutellum, and metanotum shining, finely punctured, the interspaces three or four times wider than the punctures, except on the posterior fourth of the 
mesonotum and on the metanotum, where they are smaller. Mesopleura dull, closely punctured ( 35 diameters), a short transverse crest extends from the hind margin forwards, just above the middle coxae. Dorsum of the epinotum nitidulous, a little more strongly and more closely punctured than the scutellum, the margins of the median area indicated by a narrow depressed line. A median carina extends from the base to near the apex of the area. Declivity dull, with a wide pit below the brow. Metapleura and sides of the epinotum fairly dull, closely punctured (45 diameters). Tergites and sternites almost dull, very closely and finely punctured (30 diameters). Head wider than the thorax. Clypeus five times wider than long, the anterior margin feebly convex and with an acute tooth, longer than wide at the base, on each side of the middle. Eyes strongly divergent below, the interocular distance across the base of the clypeus being eight times greater than across the vertex, where it is equal to the length of the second joint of the flagellum. First joint of the flagellum very small, not globose, the second joint three-fourths wider than long, the first to seventh wider than long, the seventh to tenth swollen below, the apical joint one and a half times longer than wide. Scutellum twice as wide as long, dorsum of the epinotum about three times wider at the base than long, as long as the scutellum, the junction with the subvertical declivity rounded. First tergite about one and a half times wider behind than long.

Basal joint of the anterior tarsi thin and very long, as long as the remaining joints united.

Hind femora and tibiae slightly compressed transversely, the tibiae with a row of about twelve very small scalariform teeth on the upper margin (45 diameters), apical margin of seventh tergite transverse. First abscissa of the radius slightly shorter than the third, and a little longer than the second.

Aleg, S. Mauritania, September I943, I ô.

\section{Tachysphex fluctuatus Gerstaecker}

1857, Mber. Akad. Wiss. Berl.: 5 Io.

Arnold, 1945, Sphecidae of Madagascar: 97.

Labadi, Gold Coast, March I94I, I o ; Meisso, Ethiopia, September I945. The second specimen has the epinotum much more strongly and more widely reticulate, and more pilose than in the typical form.

\section{Tachysphex bruneiceps Arnold}

1923, Ann. Transv. Mus. 9: 153 .

River Hawash, Ethiopia, June I946, I ㅇ.

\section{Tachysphex egregius Arnold}

1924, Ann. Transv. Mus. 11: 273 ô.

1929, Ann. Transv. Mus. 13: 384 ㅇ.

Labadi, Gold Coast, May I94I, I ô, I $q$; Tillembeya, River Niger, French Sudan, August I944, I +. 


\section{Tachysphex theseus sp. n.}

(FIG. 45)

ㅇ. Io $\mathrm{mm}$. long. Black. Apical margin of the fourth and the whole of the fifth and sixth abdominal segments ferruginous. Tarsi ferruginous, the apical joints a little darker. Wings hyaline, the veins pale brown. Face and clypeus with pale golden pubescence, thorax with a very short, sparse, and grey pubescence. Clypeus and face dull, very finely and closely punctured, the vertex nitidulous and not quite so closely punctured as the face, the temples smooth and shining.
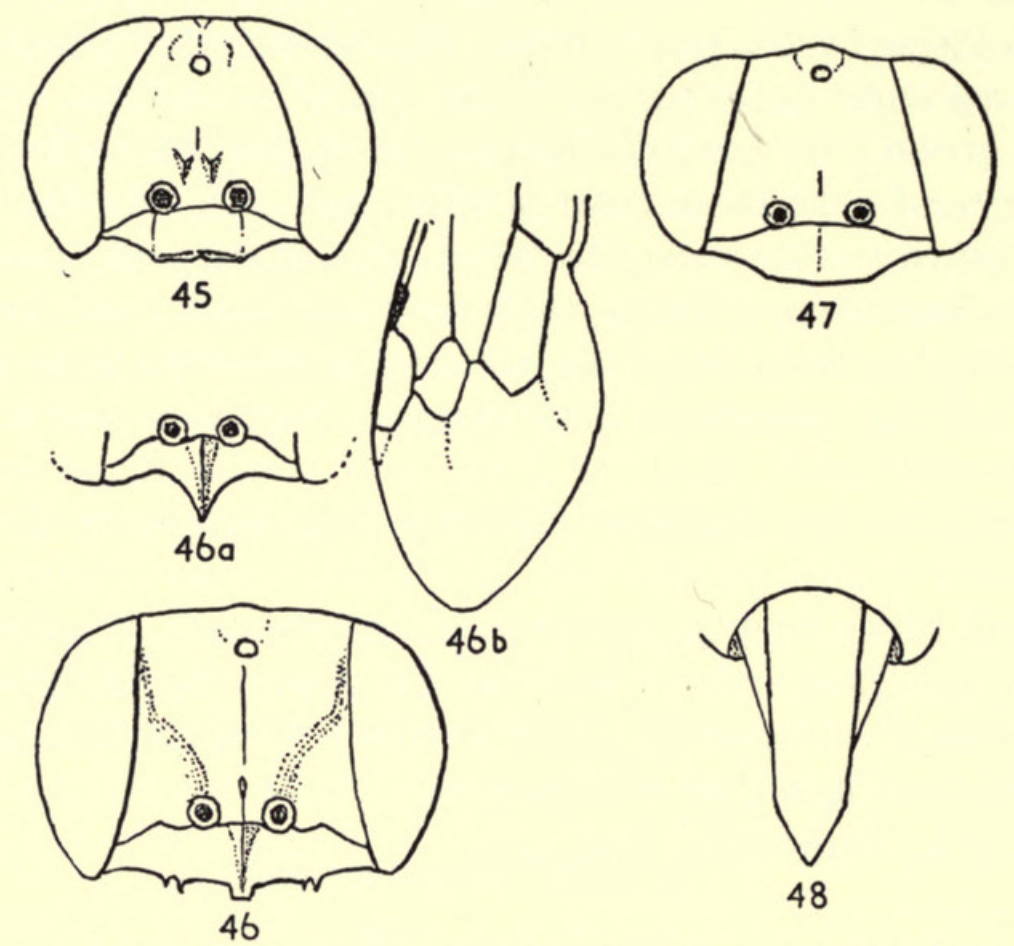

FIg. 45. Tachysphex theseus 우, $\times$ c. Io. FIg. 46. Gastrosericus fluviatilis 우, $\times$ I6. Fig. $46 a$. Gastrosericus fluviatilis 0 , clypeus, $\times$ I6. FIG. 46b. Gastrosericus fluviatilis ㅇ, wing, $\times c$. 10. FIG. 47. Gastrosericus senegalensis + , $\times$ I6. FIG. 48. Palarus rothschildi croesus ${ }_{+}$, pygidium, $\times$Io.

Mesonotum shining, punctured, the punctures about twice as large as those on the face, the interspaces from two to three times wider than the punctures, except on the margins which are very closely punctured. Scutellum and metanotum shining, their puncturation a little smaller on the face. Mesopleura finely and very closely punctured. Dorsum and declivity of the epinotum dull, fairly closely reticulate, the sides of the epinotum shining, transversely striate. Abdomen dull, impunctate, the pygidial area twice as long as wide at the base, the apex narrowly truncate.

Median area of the clypeus nearly twice as wide as long, impressed behind the anterior margin which is feebly concave in the middle. Supra-antennal tubercles prominent. Interocular distance on the vertex very nearly as long as the first two joints of the flagellum. Behind the ocellar area there is a well-defined angular depression. Flagellum slender, the second joint nearly three times longer than wide at the apex, the third joint a little longer than the second. Dorsum of the epinotum two and two-fifths wider at the base than long. Fourth joint of all the tarsi very short, 
wider than long, the claws asymmetrical, the outer claw of the anterior tarsi larger than the inner, and smaller than the inner of the middle and hind tarsi.

Accra, Gold Coast, September I94I, I 9 .

Related to T. hippolyta Arnold and T. harpax Arnold and having the claws asymmetrical as in them, but differing from both by the length and sculpture of the epinotum, the slender flagellum, and the colour of the apical abdominal segments.

Tachysphex panzeri van der Linden var. aethiopicus Arnold

1923, Ann. Transv. Mus. 9: 167 .

Labadi, Gold Coast, March I94I, 3 후శ.

\section{Atelosphex lugubris Arnold}

1924, Ann. Transv. Mus. 11: 72.

Accra, Gold Coast, September I94I, I ㅇ.

This differs to a slight degree from the type of the species, but hardly enough to justify a varietal name. The puncturation of the mesonotum in the middle is sparser, the dorsum of the epinotum is more reticulate, and the pygidial area is narrower. In the coarse puncturation and the absence of spines along the length of the hind metatarsi, the genus shows some affinity with Phytosphex Arnold, but in the latter the epicnemial suture is present.

\section{Parapiagetia capensis Brauns var. ferox Arnold}

Brauns, I9Io, Dtsch. ent. Z.: 666.

Arnold, I922, Ann. Transv. Mus. 9: 135.

Ufdem, Ethiopia, August I945, I 우 Aleg, S. Mauritania, September I943, I 우, Dakar, Senegal, August I943, I ㅇ.

The specimen from Dakar is a slight variety, having the last three abdominal segments blackish.

Gastrosericus neavei reversa subsp. n.

G. neavei Turner, 1913, Trans. Ent. Soc. Lond.: 754.

ㅇ. $8 \mathrm{~mm}$. long. The corners of the median lobe of the clypeus are not rectangular as in neavei i. sp. but produced into blunt teeth, and the wings are slightly darker. Otherwise it does not differ except in one very remarkable character in which it also differs from all other Ethiopian Sphecids known to me.

In neavei i. sp. the dorsum of the epinotum is glabrous, but in this race on each side of the median transversely rugose area there is a coarse, obliquely exserted and silvery pubescence, directed cephalad. In the ot this pubescence is less abundant, but plainly apparent if the insect is looked at caudad. Otherwise like the type of the species.

Tillembeya, River Niger, French Sudan, August I944, 4 우우, 4 충.

\section{Gastrosericus fluviatilis sp. $\mathrm{n}$.}

(Figs. 46, 46a and 46b)

․ $8 \mathrm{~mm}$. long. Black. The following parts pale yellow: basal half of the mandibles, the apex of the scapes, tegulae, apical half of the anterior femora, apical third of the 
middle and extreme apex of the hind femora, tibiae and first two joints of tarsi, the last three joints pale ferruginous. Wings hyaline, faintly smoky, the veins brown. Clypeus, lower half of the face, temples, dorsum of the pronotum, mesosterna, and lower half of the mesopleura with silvery pubescence. Epinotum with short, erect and white pubescence. Tergites I-4 with apical fasciae of grey pubescence, the pygidial area with dark golden pubescence. Sternites 3-6 shining and impunctate, the rest of the body dull, closely and microscopically punctured, the largest punctures being on the scutellum and epinotum (30 diameters). Clypeus short, five times wider than long, carinate lengthwise in the middle, and with a very short lobe on the anterior margin; between the lobe and the lateral angles there are two small teeth on each side. Interocular distance at the base of the eyes two-thirds greater than across the vertex, where it is equal to the length of the first five joints of the flagellum. Temples with a triangular tooth near the middle.

Second joint of the flagellum slightly shorter than the third and not quite twice as long as wide. Lower third of the face excavated, the upper margin of the excavated area continued as a groove margining the eyes as far as the level of the anterior ocellus.

Propleura with a transverse torus on each side in front of the hind margin. Anterior coxae triangular, the anterior margin raised and thickened. Pronotal collar barely as long as the first joint of the flagellum and lying much below the level of the mesonotum. Dorsum of the epinotum fully twice as wide at the base as long, joining the oblique declivity in a wide curve. First tergite a little longer than wide at the apex, and like the second tergite a little swollen in front of the hind margin. Pygidial area elongate-triangular, slightly shining and sparsely punctured at the base. Anterior metatarsi with six short spines on the outer margin. Second discoidal cell petiolate, the first abscissa of the radius fully three times longer than the second.

๙ $.6 \mathrm{~mm}$. long. Middle and hind tibiae with a fuscous macula on the inner side, the last four joints of the hind tarsi black. Pubescence on the clypeus and face golden. Clypeus produced in the middle into an acute tooth. Joints of the flagellum very short, the second one and a half times longer than wide. Temples without a tooth, anterior coxae less thickened in front than in the . . Otherwise like the 9.

Tillembeya, River Niger, French Sudan, August I944, I o 6 우․

Related to turneri Arnold, from which it differs, inter alia, by the shape of the clypeus and anterior coxae, the much finer puncturation of the thorax, and the venation.

\section{Gastrosericus senegalensis sp. $\mathrm{n}$.}

\section{(FIG. 47)}

ㅇ. $6.5 \mathrm{~mm}$. long. Head and thorax black, abdomen pale ferruginous. Mandibles yellow at the base, the apex of the sçapes ochreous on the upper side. Femora fuscoferruginous, the fore and middle pairs yellow at the apex, tibiae and tarsi pale ferruginous, the tibiae pale yellow on the upper side. Wings hyaline, the veins ochreous. Head and thorax with a very short adpressed and yellowish-silvery pubescence, without any long pilosity. Tergites with a thin and microscopic greyish pubescence. The whole body dull and, excepting the pygidial area, very closely and microscopically 
punctured (50 diameters), the dorsum of the pronotal collar with traces of transverse rugulosity. Pygidial area shining, sparsely punctured, twice as wide at the base as long.

Clypeus three times wider than long, subcarinate in the middle, the anterior margin convex and without teeth. Eyes divergent below, the interocular distance at their base half as great again as across the vertex, where it is equal to the length of the first three joints of the flagellum plus half of the fourth. The second joint about twice as long as wide, and as long as the third. Temples unarmed. Dorsum of the pronotum narrowed anteriorly, fairly long, as long as the first joint of the flagellum. Dorsum of the epinotum twice as wide at the base as long, with a very indistinct basal triangular area. Anterior metatarsi with five long spines on the outer margin. First abscissa of the radius twice as long as the second, the recurrent veins contiguous on the second cubital cell.

Dakar, Senegal, August I943, I ㅇ․

Smaller than the Egyptian G. waltii Spinola and without the long pubescence on the head and thorax and rugose sculpture of the epinotum present in that species. It differs from $G$. capensis Brauns in the much finer sculpture and dull surface of the head and thorax and by the absence of a long and woolly pubescence on those parts.

\section{Liris (subgen. Motes) nugax Kohl}

1894, Ann. naturh. Hofmus. Wien, 9: 302.

Dilla, Ethiopia, April I943, I 웅 Didessa River, Ethiopia, June r946, I

\section{Liris (Motes) croesus Smith}

1856, Cat. Hymen. B.M. 4: 284 .

Diafarabé, Senegal, August I944, I o .

\section{Liris (Motes) solstitialis Smith}

1856, Cat. Hymen. B.M. 4: 283.

Aburi and Accra, Gold Coast, August to September I94I, I ô, I ㅇ.

Liris (Motes) rugifera Turner

1918, Ann. Mag. Nat. Hist. (9), 5: 362.

Accra, Gold Coast, September, I 9 .

Liris (Motes) thysanomera Kohl

1894, Ann. naturh. Hofmus. Wien, 9: 302.

Accra and Aburi, Gold Coast, December I94I, 3 우오.

Liris (Motes) antaca transvaalensis Cameron

Arnold, 1945, Sphecidae of Madagascar: I26.

Adis Ababa and River Hawash, Ethiopia, August and June, 2 우.

ENTOM. 2. 3 
Liris (Motes) egregia Arnold

1929, Ann. Transv. Mus. 13: 395.

Adis Ababa and Dilla, Ethiopia, June, 2 శోశ.

Liris (Motes) setigera Arnold

1940, Ann. Transv. Mus. 20: 123.

Tillembeya, River Niger, French Sudan, August I944, I ơ.

Liris (Motes) denticulata Turner

1920, Ann. S. Afr. Mus. 17: 496.

Accra and Labadi, Gold Coast, September and March I94I, 2 웅․

These represent a slight variety in which the tarsi are ferruginous instead of brownish-black.

Liris (Motes) flavitincta Arnold

1940, Ann. Transv. Mus. 20: I4r.

Accra, Gold Coast, September I94I, I ㅇ.

Liris (Motes) abyssinica Arnold

1933, Ann. Mag. Nat. Hist. (Iо) ry: 353.

Fiché, Ethiopia, October I945, I $\widehat{0}$.

Liris (Motes) gracilicornis Arnold

1923, Ann. Transv. Mus. 9: 250.

Labadi, Gold Coast, March I94I, I ․

Liris nigricans Walker race reticulata Saussure

I871, List Hymen. Egypt: $2 \mathrm{I}$.

Arnold, 1945, Sphecidae of Madagascar: 132.

Dilla, Ethiopia, April I948, 2 추.

Palarus rothschildi croesus subsp. $\mathrm{n}$.

(FIG. 48)

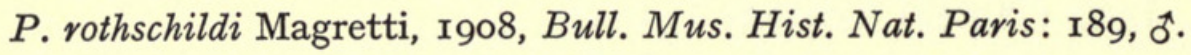

The insect described hereunder agrees in the main with the description of rothschildi, but there are differences in structure as well as in colour. Not much importance attaches to the latter, and since it appears to me improbable that Magretti overlooked the structural characters it seems more prudent to treat this as a subspecies.

f. $9.5 \mathrm{~mm}$. long. The yellowish-white markings on the scutellum are confined to the posterior angles, the epinotum is entirely black, the pale maculae on the tergites are present on the fifth and sixth as well as on the four basal tergites. Mesopleura without any transverse striation. Excepting a small round and smooth area in front of the hind margin, the whole of the epinotal dorsum is strongly reticulate-rugose. Sixth sternite with an acute curved tooth on each side, the seventh bluntly triangular, the apical without two small teeth. Otherwise like rothschildi $\mathrm{i}$. sp. In the original 
description 'supra ocellum magnum' is evidently a lapsus calami, the triangular swelling on the face being below, and not above, the anterior ocellus.

ㅇ. I $2 \mathrm{~mm}$. long. Anterior half of the mesopleura dirty yellow, stained in parts with red. The dorsum of the epinotum with a yellowish-white macula on each side. The pale maculae on the first five tergites cover the greater part of the segments but do not reach the basal and apical margins. Second to fourth sternites ferruginous, blackish at base and apex and with a narrow yellow apical line, interrupted in the middle. Sixth tergite and sternite ferruginous.

Supra-antennal swelling less triangular than in the $\sigma^{*}$. Interocular distance on the vertex equal to a little more than the length of the first joint of the flagellum. The second joint is a little more than two and a half times longer than wide and onefourth longer than the third. First tergite with a short and acute tooth on each side of the vertical anterior face and near its dorsal boundary, the sides of the dorsal face not angular posteriorly as in the $\sigma^{*}$. The transverse crest on the second sternite is not broad and flat on its vertical face as in the $\sigma^{*}$, but is low and has a trenchant edge which bears seven small teeth. Pygidium long, the sides with large elongate punctures, the dorsal face dull, very finely, closely, and longitudinally striate, at least three times longer than wide at the base.

Ufdem, Ethiopia, I ô, I +9.

Related to P. O'Neili Brauns, from which it differs in the ot by smaller size, the colour, the shape of the first tergite, and in the $q$ by the colour, the sculpture, and shape of the epinotal declivity.

\section{Palarus obesus sp. n.}

(FIG. 49)

ㅇ. I2 $\mathrm{mm}$. long. Mandibles pale yellow at the base, ferruginous at the apex. Clypeus yellowish-white, the rest of the head and the thorax black, the posterior margin at the pronotum excepting the middle, the tegulae, a spot on the mesopleura below the tegulae, the posterior lateral margin of the scutellar area and the metanotum, yellowish-white. First and second abdominal segments pale ferruginous, the third to fifth blackish, the sixth ferruginous, the first to fifth tergites with pale yellow transverse bands, those of third, fourth, and fifth emarginate in the middle of the posterior margin. Fore and middle femora yellowish-white below, the anterior pair black above, the middle pair ferruginous above. Hind femora ferruginous, the extreme apex yellowish, tibiae and tarsi pale ferruginous. Wings hyaline, the veins ochreous. Clypeus, face, and thorax, excepting the epinotum, with silvery pubescence, very sparse on the thorax; temples and epinotum with long white pilosity. Apical margins of the abdominal segments with a few long yellowish hairs.

Clypeus dull, closely and finely punctured, subcarinate lengthwise in the middle, half as wide again as long, the anterior margin convex. Face dull, closely and finely punctured, the space behind the anterior ocelli shining, sparsely punctured, and sharply carinate. Eyes contiguous on the vertex.

Mesothorax and mesonotum nitidulous, sparsely, finely, and very shallowly punctured. Metapleura smooth. Epinotum dull, microscopically reticulate. Abdomen 
shining, finely and sparsely punctured. Sixth tergite dull, lanceolate, the sides strongly marginate and with a median carinate area which is longitudinally rugose, the space between the median area and the sides obliquely rugoso-punctate; sixth sternite coarsely punctured, and with a strong median carina.

Flagellum moderately clavate, the second joint nearly three times longer than wide

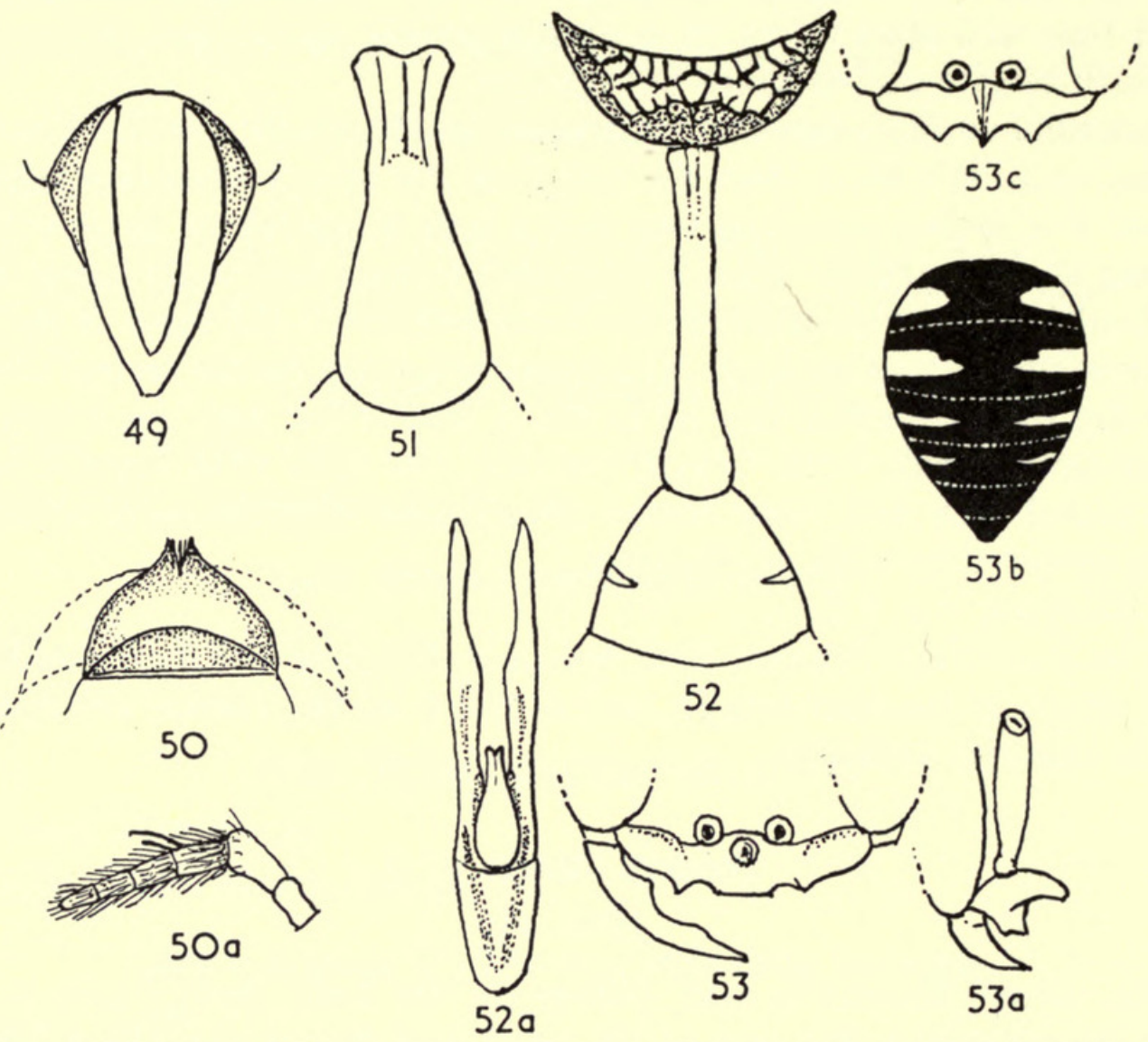

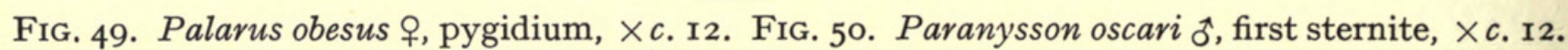
Fig. 50a. Paranysson oscari ${ }^{\star}$, maxillary palp, $\times 27$. Fig. 5I. Dasyproctus basifasciatus petiole, $\times$ I8. FIG. 52. Dasyproctus stevensonianus occidentalis ô, epinotum and petiole, $\times$ I8. FIG. 52a. Dasyproctus stevensonianus occidentalis 0 , genitalia, $\times 24$. FIGs. 53 and $53 a$. Oxybelus coniferus , clypeus, $\times I_{5}$. FIG. 53b. Oxybelus coniferus, abdomen, $\times 7 \frac{1}{2}$. Fig. 53c. Oxybelus coniferus 0 , clypeus, $\times 15$.

and twice as long as the third, the latter a little longer than wide, the fourth and apical as long as wide, the other joints wider than long. Dorsum of the epinotum a little shorter than the scutellum, shallowly depressed in the middle; the declivity vertical, with a median triangular depression, the apex ventrad. Pygidial area nearly twice as long as wide at the base. Anterior tarsi with a well-developed comb, the basal joint with six yellow spines on the outer margin. Second cubital cell with a very short stalk, the second abscissa of the radius two-thirds longer than the first. The first recurrent vein meets the first cubital cell not far from the first transverse cubital vein, the second meets the second transverse cubital vein. Radial cell not appendiculate.

Podor, S. Mauritania, September I943, 2 웅․

Apparently more closely related to the Indian P. comberi Turner than to any of the African species, differing from it by the shape of the yellow markings on the 
abdomen, the coarse puncturation of the mesonotum, and the colour of the legs. The shape of the pygidial dorsum appears to be the same, judging by Turner's description.

\section{Paranysson oscari Turner}

(FIGS. 50 and $50 a$ )

1914, Ann. Mag. Nat. Hist. (8) 14: 34I, ㅇ.

Aburi, Gold Coast, December I94I, 3 충․

In this species the maxillary and labial palpi are densely pubescent, and the basal sternite is very convex, rising caudad, and is sharply truncate a little in front of the hind margin. In P. helioryctoides Turner the basal sternite is similar, but as it does not rise so high caudad, the face of the truncation is shorter.

\section{Subfamily Pemphredoninae}

\section{Psenulus pauxillus laevior subsp. $\mathrm{n}$.}

P. pauxillus, Arnold, I947, Occ. Pap. Nat. Mus. S. Rhod. 2: I59.

o. $6.5 \mathrm{~mm}$. long. Femora brown. Mesonotum one and a half times wider than long, wider than in pauxillus i. sp. in which it is only one and two-fifths wider, less strongly and less closely punctured, and without the feeble transverse ridges between the punctures. The dorsum of the epinotum is only feebly rugulose at the sides and the $Y$-shaped groove is narrower. The interocular distance on the vertex is shorter, being equal to the length of the first three joints of the flagellum plus half of the fourth.

Gambeila, Ethiopia, February I948, I o $^{*}$

\section{Subfamily CrabroninaE}

All the specimens in this collection belong to the species-group Dasyproctus. For the validity of genera and subgenera in this subfamily, as opposed to species-groups, I would refer the reader to my remarks on the subject in my Monograph of the Sphecidae of Madagascar, I945, p. I57.

\section{Crabro (Dasyproctus) oedignathus Arnold}

1933, Ann. Mag. Nat. Hist. (1о) 11: 355, ơ.

Adis Ababa, Wondo, Akaki, Mount Chillala (8,000-9,00o ft.), Ethiopia, II 충, 3 우오.

․ II mm. long (hitherto undescribed). Pubescence on the clypeus pale golden, the sixth tergite entirely black. The puncturation on the vertex behind the brow of the face finer, and the sculpture of the epinotum is also finer, the median triangular area is without longitudinal rugae and is only reticulate-rugose. Mandibles of the usual shape, not angularly dilated near the base as in the $\sigma^{t}$. Second joint of the flagellum two and two-thirds longer than wide (twice as long as wide in the $\delta^{\star}$ ); the fifth joint not dilated below. Otherwise like the $\widehat{o}$. 
Crabro (Dasyproctus) pullatus uniguttatus subsp. $\mathrm{n}$.

C. pullatus Arnold, 1944, Occ. Pap. Nat. Mus. S. Rhod. 2: 3 o.

o. $8-8.5 \mathrm{~mm}$. long. Pronotal tubercles straw-yellow. The vertex in front of the anterior ocellus is much more strongly punctured than in pullatus i.sp. The punctures are about one-fourth as wide as the anterior ocellus and the interspaces are two and a half times wider than the punctures. The node of the petiole is a little thicker.

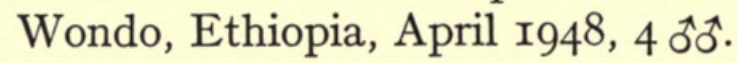

\section{Crabro (Dasyproctus) basifasciatus sp. $\mathrm{n}$.}

(FIG. 5I)

․ $9.5 \mathrm{~mm}$. long. Black. The following parts lemon-yellow: scapes, pronotal dorsum except in the middle, pronotal tubercles, a small spot on the anterior angles of the scutellum, transverse and narrow bands, interrupted in the middle, at the extreme base of the third and fourth tergites, the upper sides of the fore and middle tibiae, and a spot near the apex of the hind tibiae. Tarsi fusco-ferruginous. Mandibles ferruginous. The sculpture hardly differs from that of $C$. dubiosus Arnold, but under a high magnification (30 diameters) the mesonotum and scutellum have minute punctures with interspaces three to four times wider than the punctures. The posterior corners of the mesonotum and the sides of the scutellum have a few very low longitudinal rugae.

Clypeus like that of $d u b i o s u s$, the median lobe a little more deeply excised. The second joint of the flagellum a little thicker, being two and a third times longer than wide (nearly three times in dubiosus). The petiole of the abdomen is much shorter than in dubiosus or in any other species of the group excepting C. ruficaudis Arnold and $C$. barkeri Arnold; it is two and a half times longer than wide across the node, whereas in dubiosus it is nearly three times longer.

Moggio, Ethiopia, April I948, I + .

Closely related to dubiosus, from which it differs by the shorter and thicker petiole and the ground colour of the legs, and the position of the yellow bands on the tergites.

\section{Crabro (Dasyproctus) stevensonianus occidentalis subsp. $\mathrm{n}$.}

(FIGS. 52 and $52 a$ )
C. stevensoni Arnold, 1926, Ann. Transv. Mus. 2: 369 .
C. stevensonianus Arnold (nom. nov.), I940, ibid. 20: I35.

f. $7 \mathrm{~mm}$. long. This race differs from the type of the species as follows: scapes with a brown macula on the inner side below. Anterior tibiae yellowish-red below, dark brown above, all the tarsi brownish-black, all the rest of the legs black. The yellow maculae on the second tergite duller and smaller. The reticulations on the epinotum are much higher and wider apart.

As in the type of the species $\hat{o}$, the petiole is five times longer than wide across the node.

Aburi, Gold Coast, December I944, I ô. 
Crabro (Dasyproctus) bipunctatus Lepeletier var. avius var. nov.

D. bipunctatus Lepeletier, 1834, Ann. Soc. Ent. Fr. 3: 802.

o. $7 \cdot 5-8 \cdot 5 \mathrm{~mm}$. long. This differs from the type of the species as follows. Tegulae black. Fore and middle tibiae and tarsi fusco-ferruginous, all the rest of the legs black. Wings hyaline, slightly smoky, the veins and pterostigma black. Pronotal collar shorter, shorter than the first joint of the flagellum (distinctly longer in bipunctatus i. sp.), the median groove much shallower and narrower.

ㅇ. $8.5 \mathrm{~mm}$. long. The face and middle tibiae ferruginous. Otherwise like the $\mathrm{o}$.

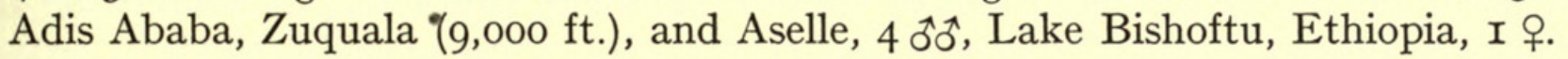

\title{
Subfamily OxybeLINAE
}

\section{Oxybelus coniferus sp. n.}

\author{
(FIGs. 53, 53a-c)
}

ㅇ. 6.5-7.8 mm. long. Black. The following parts yellowish-white: a short and transverse streak on each side of the pronotal dorsum, small spots, sometimes absent, on the anterior corners of the scutellum, the metanotum, transverse and more or less lanceolate maculae on each side of the first four tergites. Anterior tibiae dirty white on the upper side. Apical joint of the tarsi pale brown. Wings hyaline, slightly smoky, veins dark ochreous to black. Tegulae fusco-ferruginous. Mandibles sometimes yellowish-red on the basal half. Mandibles, clypeus, lower half of the face and temples with silvery pubescence.

Metanotum and scutellum with erect, brownish-grey pubescence, the pleura, sterna, and femora below with white and thin pubescence. Median area of the clypeus shining, the anterior margin convex and with a blunt tooth on each side, the base with a transversely compressed, and slightly curved conical protuberance, its apex rounded. The space behind the scapes shining and very finely punctured, the rest of the head dull, very closely punctured, the interspaces not wider than the punctures; on the occiput and temples striated between the punctures. Pronotal dorsum very short, almost linear in the middle, the lateral angles acute. Mesonotum and scutellum shining, a little more strongly punctured than the vertex, the interspaces narrower than the punctures and slightly raised longitudinally, or subrugose. Metapleura nitidulous, coarsely reticulate-rugose. Metapleura strongly, sides of epinotum finely and transversely striate. Metanotum shining, longitudinally and not closely costate. The lateral squama black, rostrate and acute at the apex. Epinotal process canaliculate, narrowed towards the apex which is excised, half as long again as wide at the base. Median triangular area of the epinotal dorsum with eight transverse costae which extend over the lateral areas, the interspaces dull, very finely reticulate. Declivity of the epinotum dull and transversely rugose outside the median triangular space.

Abdomen shining, the tergites very sparsely punctured on the yellow areas at the sides, fairly closely over the basal half and at the apical margin. Pygidial area dull, closely punctured, triangular, the apex truncate. Second sternite sparsely and coarsely punctured, excepting the sides which are closely and finely so. Eyes 
moderately divergent above and below, the interocular distance on the vertex equal to the length of the flagellum, less the apical joint. Posterior ocelli twice as far from each other as from the eyes. Between the posterior ocelli and the eyes there is a low and oblique torus. Comb of the anterior tarsi ochreous, the basal joint with six spines on the outer margin.

o. $6.2 \mathrm{~mm}$. long. Femora with a dull yellow macula on the upper side at the base. Face and mesonotum with a slight aeneous tint. Pale maculae on the first to fifth tergites, smaller than in the $q$ and of a chrome-yellow colour. Median area of the clypeus with a longitudinal carina, wide at the base, projecting as a tooth on the concave anterior margin. Pygidial area trapezoidal. Otherwise like the ㅇ.

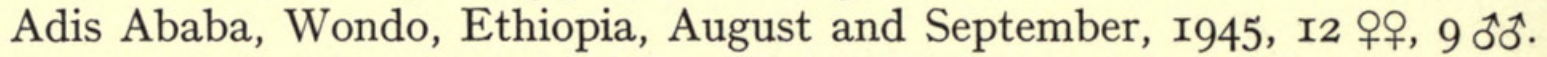

Related to $O$. pilosus Arnold, from which it differs in both sexes by the greater size, in the $q$ by the shape of the clypeus and its basal process, black pronotal tubercles, stronger puncturation of the mesonotum and tergites, entirely black flagellum, and colour of the tarsi. In the $\hat{\sigma}$, it differs from pilosus by the colour of the legs and of the flagellum.

\section{Oxybelus acutissimus Bischoff var. propinquus Arnold}

1927, Ann. Transv. Mus. 12: 83 .

Haramaia, Ethiopia, May, I948, 3 우.

\section{Oxybelus pictus Arnold}

1927, Ann. Transv. Mus. 12: II5.

Tillembeya, River Niger, French Sudan, September I944, I q.

This specimen is a slight variety, differing from the type of the species by the less close puncturation of the mesonotum, by the stronger sculpture of the lateral areas of the epinotal dorsum, and by the presence of narrow pre-apical yellow bands on the third and fourth tergites as well as on the first and second.

\section{Oxybelus curviscutis Arnold}

1927, Ann. Transv. Mus. 12: rog.

Accra, Gold Coast, Tillembeya, River Niger, French Sudan, Dakar, Senegal, and Haramaia, Ethiopia, 5 우우, 4 후오.

The $q$ from Tillembeya is a variety with a reddish pygidium.

\section{Oxybelus pallidus Arnold}

1927, Ann. Transv. Mus. 12: ror.

Ufdem, Ethiopia, August I945, 2 హై

\section{PART II. POMPILIDAE}

This interesting collection of Pompilidae made by Mr. K. M. Guichard and now the property of the British Museum (Natural History) comprises I62 specimens of which a considerable proportion is too defective, lacking antennae or tarsi or wings, to 
permit of identification; but it has, nevertheless, been possible to work out the great bulk of it quite satisfactorily.

\section{Subfamily Pepsinae}

I843, Hymen. Eur. 1: 123.

\section{Genus Hemipepsis Dahlbom}

Arnold, 1932, Ann. Transv. Mus. 14: 318-319.

Arnold, 1948, Occ. Pap. Nat. Mus. S. Rhod. 14: 233.

The collection contains twelve specimens of which seven are males. These do not agree with any of the species I have seen, and in view of our present knowledge of the genus and also of the absence of the corresponding females, it would be unwise to describe them as new. I have elsewhere (I932) expressed the opinion that the genus is of recent origin on account of the uniformity of the male genitalia. It is therefore difficult to correlate the sexes unless they are taken in copula. The copulatory act is probably of very short duration, as in the Sphecidae, for in nearly forty years of collecting in S. Rhodesia I have only once taken a Pompilid species copulating, Anoplius fuscus montivagus Arnold. Both sexes may occasionally be seen on trees of which the flowers have short corollas, such as Rhus and Zizyphus, but as the reproductive phase in both sexes is then past, they pay no attention to one another, so that their proximity is of little use in correlating the sexes.

1913, Rev. Zool. Afr. 3: 193.

\section{Hemipepsis aethiops Kohl}

Didessa River, western Ethiopia, 25 May I946, I 9 . The type was taken at Mpika, N. Rhodesia, not Belgian Congo as stated in Kohl's work.

\section{Hemipepsis fallax Saussure}

I892, in Distant: Nat. Transvaal: $22 \mathrm{I}$.

Didessa River and Lekempti, Ethiopia, May I946, 2 б주.

\section{Hemipepsis iodoptera meridionalis Arnold}

Arnold, 1932, Ann. Transv. Mus. 14: 361.

Kpeve, Gold Coast, June I942, I ô.

A variety of this race in which the colour of the head and pronotum is castaneous red.

Hemipepsis glabrata anchietae Radoszkovsky

Radoszkovsky, 1881, J. Sci. Mat. Phys. Nat. Lisboa, 8: 213.

Meisso, Ethiopia, 4 September I945, I o $^{*}$.

Cyphononyx flavicornis Fabricius var. antennatus Smith

I78r, Spec. Insect, 1: 450.

Smith, I855, Cat. Hymen. B.M. 3: I86.

Lake Bishoftu, 7,000 ft., May I946, 2 우; Asba Tafari, Ethiopia, 7,800 ft., September I945, I ô.

ENTOM. 2. 3 


\section{Cyphononyx optimus Smith}

I855, Cat. Hymen. B.M. 3: I4I.

Ghedo, 7,000 ft., May I946, I ô; Goré, Ethiopia, 6,000 ft., February I948, I ô.

\section{Cryptocheilus impressiceps Arnold}

I932, Ann. Transv. Mus. 14: 376.

Gorgora, Lake Tana, II December I945, I ㅇ․

A slight variety in which the red parts of the head and thorax are much darker than in the type of the species. It should be noted that in this species the width of the vertex is slightly variable. In the type it is equal to the length of the second joint of the flagellum which is five times longer than wide at the apex; in the paratopotype (in the Nat. Mus., S. Rhod.) the interocular distance is fully one-fourth greater than the length of the second joint, and in specimens from Matetsi, S. Rhodesia (in the Nat. Mus., S. Rhod.), it is nearly one-sixth greater, or equal to the length of the first two joints of the flagellum.

\section{Cryptocheilus rhodesianus senegalensis subsp. $\mathrm{n}$.}

\section{C. rhodesianus Arnold, 1932, Ann. Transv. Mus. 14: 372.}

ㅇ. I2. $5 \mathrm{~mm}$. long. This form differs from the type of the species as follows: wings less deeply clouded, the fuscous cloud on the basal vein absent, the distal cloud covers only the lower two-thirds of the second cubital cell and the middle of the upper half of the second discoidal cell. The flagellum is thinner, the second joint being nearly five times longer than wide at the apex. The mandibles and clypeus are entirely black. Interocular distance on the vertex equal to the length of the second joint of the flagellum plus half of the first. Each of the scales on the hind tibiae overhang only one spine, not two as in the type.

Diafarabé, French Sudan, I4 August I944, type; Tillembeya, River Niger, French Sudan, August I944, I ㅇ․

\section{Priocnemis modestus sp. n.}

(FIG. 54)

ㅇ. $9.5 \mathrm{~mm}$. long. Black. Scapes, second joint of the flagellum, and base of the third joint ferruginous. Legs, excepting the coxae and trochanters, pale ferruginous. Wings smoky, with a fuscous cloud over the apex of the medial cell, and another fuscous cloud covering the radial, second, and third cubital cells, excepting their upper margin, and the outer upper half of the second discoidal cell. Last two joints of the tarsi brown. Mandibles with a few long yellowish hairs. Basal half of the sixth tergite with a dense brown pilosity. Apical margin of the clypeus slightly reddish, not quite dull, and with a transverse row of large punctures. The rest of the clypeus, the face, vertex, promesonotum, and mesopleura dull, reticulate-punctate, the face and scutellum more strongly punctured (30 diameters) than the other parts. Upper half of the metapleura strongly and obliquely striate, the lower half very finely and closely striato-punctate. Epinotum dull, closely transversely rugulose, the rugae stronger and farther apart on the declivity, which is also somewhat reticulate. Abdomen shining, with a microscopic brown pubescence. Clypeus two and two-thirds 
wider than long, the apical margin feebly concave. Inner orbits slightly divergent below. Interocular distance on the vertex equal to the length of the second joint of the flagellum. Posterior ocelli two and a half times farther from the eyes than from each other. Second joint of the flagellum nearly five and a half times longer than wide
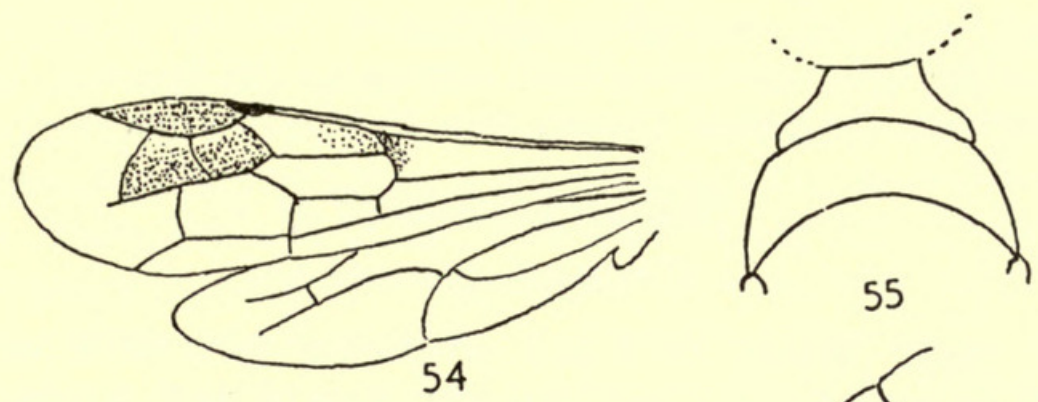

55
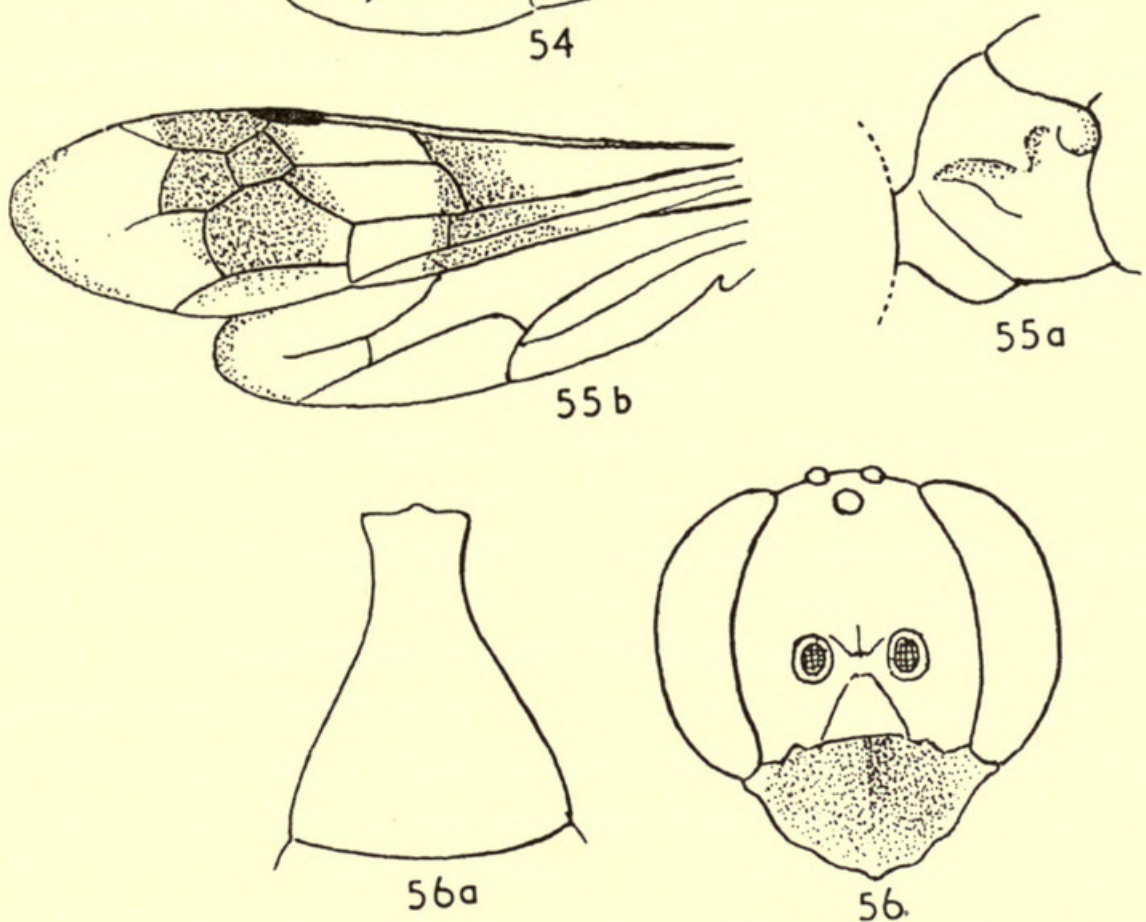

FIG. 54. Priocnemis modestus $ᄋ$, wings, $\times$ c. 7 . FIGs. 55 and 55 . Marimba guichardi $ᄋ$, pronotum, dorsal and lateral view, $\times$ I2. FIG. 55b. Marimba guichardi o, wings, $\times 7$. FIG. 56. Pseudagenia accraensis +, head, $\times$ I2. FIG. 56a. Pseudagenia accraensis o, first tergite, $\times$ I 2 .

at the apex and fully one-third longer than the third joint. Temples nearly as wide as the eyes. Postnotum with a median groove, as long as the metanotum. The junction of the epinotal dorsum with the declivity not clearly delimited, the two forming in profile a low and unbroken arc, the whole segment one-seventh longer than wide. First tergite a little longer than wide at the hind margin, four and a half times wider there than at the base. Second abscissa of the radius four times longer than the first and one-third longer than the third. The first recurrent vein meets the cubitus a little before the middle of the second cubital cell, the second meets the third cubital cell at the end of its proximal third. Nervulus distinctly postfurcal. Cubitus of the hindwing emitted a little beyond the end of the submedial cell. Hind tibiae with a row of nine scales each overlapping a spine, and with a row of spines on each side of the row of scales. Claws with an acute tooth in the middle.

Dilla, Ethiopia, April I948, I ㅇ. 
Not closely related to any other Ethiopian species. The colour resembles that of $P$. inermis Arnold, which is a larger species and with much stronger sculpture.

\section{Subfamily Ctenoceratinae}

\section{Genus Marimba Pate}

Pate, 1946, Trans. Amer. Ent. Soc. 12: 93 and roo.

Turner (Cryptosalius), I918, Ann. Mag. Nat. Hist. (9) 1: 354-355.

Arnold (Parapompilus), 1932, Ann. Transv. Mus. 15: 89, I04-106.

\section{Marimba guichardi sp. $\mathrm{n}$.}

(FIGS. 55, 55a and 55b)

ㅇ. II.5 mm. long. Black, head and prothorax very dark reddish-brown. First six joints of the antennae, legs, and extreme apex of sixth tergite, fusco-ferruginous. Wings hyaline, bifasciated, the inner fascia covering the apical two-fifths of the medial, first submedial and anal cells and the base of the second submedial and first discoidal cells, the outer fascia covering the radial cell excepting the apex, the second and third cubital, the apex of the first cubital cell and first discoidal cell, and the second discoidal cell excepting the base. Flagellum, mesosternum, and coxae covered with a decumbent, very fine and silvery pubescence. Lower corners of the epinotum with exserted silvery pubescence, the apical margins of the first three tergites with decumbent silvery pubescence at the sides. Labrum semicircular, the galea extending beyond the closed mandibles, the latter with a tooth behind the apex. Clypeus microscopically and closely punctured, with a greasy lustre, nearly three times wider than long, the anterior margin straight. Face finely and very closely punctured (25 diameters), the interspaces as wide as the punctures. Inner orbits parallel. On each side of the bottom of the face there is a deep circular pit, half on the face and half on the clypeus. Inter-antennal tubercle prominent; a narrow impressed line extends from it to the anterior ocellus. Posterior ocelli very little farther from each other than from the eyes. Interocular distance on the vertex equal to the length of the second joint of the flagellum plus two-ninths of the third joint; the second joint is slightly more than three times longer than wide at the apex and the third joint is one-sixth longer than the second. The puncturation of the dull promesonotum and scutellum is like that of the face but a little larger. The dorsum of the pronotum merges gradually into the anterior face, the sides are nitidulous, with a few large punctures, and the transverse groove is wide. Mesonotum three times longer than the pronotum. Scutellum very convex, subcarinate lengthwise in the middle.

Postnotum much shorter than the metanotum and depressed. Mesopleura coarsely rugose, pitted between the rugae. Metapleura obliquely costate. Dorsum of the epinotum two-thirds wider than long, shining, very coarsely and transversely rugose, with numerous anastomoses or almost reticulate-rugose, the interspaces wide, about as wide as the ocelli, the sides more closely rugose, the declivity oblique, shining, and with seven transverse rugae. Abdomen lanceolate, two and two-thirds longer than wide across the middle, the first tergite as long as wide behind and four times wider there than at the base. Sixth tergite longer than wide at the base, the apex subacute. Transverse groove of the second sternite between the first and second third of the 
segment. Second abscissa of the radius a trifle longer than the third and four times longer than the first. Cubitus of the hindwing emitted a little before the end of the submedial cell. Claws bifid.

Dilla, Ethiopia, April I948, I +.

Apparently closely related to $M$. indocilis Turner, which I have not seen, but differing therefrom according to Turner's description as follows: the smaller size, the colour of the legs and basal joints of the antennae, the shorter second abscissa of the radius, and the close puncturation of the promesonotum. From $M$. contristans Turner it differs also by the puncturation of the pro- and mesothorax, the smaller size, and the colour of the wings. These two species and two others from Africa were described by Turner (IgI8) and placed in his genus Cryptosalius (genotype C. rava Bingham). In my monograph of the Ethiopian Pompilidae I placed Cryptosalius in synonymy with Parapompilus. However, Pate (I946) indicated that Turner's African species were not congeneric with C. rava and proposed for them the new generic name Marimba. These species and the one described above differ from Parapompilus in the absence of a tarsal comb, the fasciated wings, and the long and very coarsely sculptured epinotum. Another distinction mentioned by Pate, 'the humeral angles of the pronotum not broadly rounded as in Parapompilus', does not hold good, as in this species, guichardi, they are rounded. Until the males are known, the relationship of Marimba with Parapompilus cannot be decided.

\section{Subfamily Pseudageninae}

\section{Pseudagenia pseudocyphononyx Turner}

I918, Ann. Mag. Nat. Hist. (9) 1:352.

Adis Ababa, 3 August I945; Zuquala, Ethiopia, October I945, 2 웅․

Somewhat smaller and with shorter wings than in the type and specimens from S. Rhodesia.

\section{Pseudagenia accraensis sp. $\mathrm{n}$.}

(FIGs. 56, 56a)

ㅇ. I6 $\mathrm{mm}$. long. Mesopleura, metanotum, metapleura, epinotum, and the first three abdominal segments black, the rest of the body, the antennae, and legs pale ferruginous. Wings very pale yellowish-brown, slightly darker over the radial, second cubital, and the upper half of the second discoidal cells, but not fasciated. Face and clypeus with a microscopic reddish pubescence. Mesopleura closely and very finely reticulate rugose, metapleura closely striate, epinotum closely, transversely, and finely rugose, the rugae strongest on the posterior half of the epinotal dorsum. Clypeus very convex transversely, nearly half as wide again as long in the middle, the anterior margin convex, with a slight projection in the middle. Interocular distance across the base of the clypeus one-third greater than across the vertex, where it is equal to three-fourths of the length of the second joint of the flagellum. Posterior ocelli as far from the eyes as from each other. Flagellum long and slender, all the joints excepting the first at least six times longer than wide, the second joint nearly seven times longer than wide at the apex and one-seventh longer than the third. 
Scutellum fairly flat, two-thirds as long as wide at the base. Postnotum shining, finely and transversely striate, as long as the metanotum. The whole epinotum is as long as wide at the base, the dorsum merges gradually into the declivity, the whole forming a low curve in profile. First tergite one-fifth longer than wide, very narrow basad. Second abscissa of the radius three times longer than the first, and half as long again as the second. The wings extend back to the apex of the abdomen.

Accra, I94I, I ㅇ.

The species nearest to this one is $P$. lijae Arnold, from which it differs by the longer clypeus, the narrower vertex, the much more slender antennae, the longer peduncle of the first tergite, and the colour of the wings.

\section{Pseudagenia stigmalis R. Lucas}

I898, Deutsch Ost-Afr. (3) 4:6r.

Arnold, 1934, Ann. Transv. Mus. 15: 342, 346.

Adis Ababa, 3 August I945, 2 웅․

It is with some hesitation that I ascribe these two specimens to this species, since the original description is quite inadequate. They appear to differ only in having the hind femora entirely ferruginous, and the face also of that colour excepting a black streak adjacent to the antennal sockets.

\section{Pseudagenia laevigata Smith}

1855, Cat. Hymen. B.M. 3: 143 .

Accra, Gold Coast, June I94I, 2 웅․

Pseudagenia flavotegulata Bingham

1902, Ann. Mag. Nat. Hist. (7) 9: 208.

Kaolack, Senegal, August I943, I ㅇ.

A slight variety in which the base of the hind coxae on the upper side, the first abdominal segment and the sides and pre-apical bands on the second and third tergites, and the middle of the second and third sternites are black.

\section{Pseudagenia infantula Kohl}

1894, Ann. naturh. Hofmus. Wien, 9: 307.

Lake Bishoftu, Ethiopia, July I945, I 우.

This specimen represents a slight variety in which the vertex is a little narrower, being equal to the length of the second joint of the flagellum, and the first tergite as long as wide behind. The distinctive shape of the clypeus is exactly like that of infantula i. sp.

\section{Pseudagenia albosignata sp. n.}

(FIGS. 57, $57 a$ and $57 b$ )

. $8 \mathrm{~mm}$. long. Black. Clypeus, excepting the basal half of the middle, and the sides of the face to a little beyond the level of the antennal sockets, dirty white. Legs ferruginous, the coxae, trochanters, and tarsi brown. Wings hyaline, with a pale 
fuscous cloud over the basal vein and nervulus, and an outer fuscous cloud covering the basal third of the radial cell, the greater part of the second cubital cell and a small area on the upper part of the second discoidal cell; the apex of the forewing also slightly fuscous. Clypeus and face with a sparse brownish pilosity, the temples, coxae, posterior half of the mesosternum and posterior angles of the epinotum with a decumbent silvery pubescence, the latter and the mesosternum and metapleura

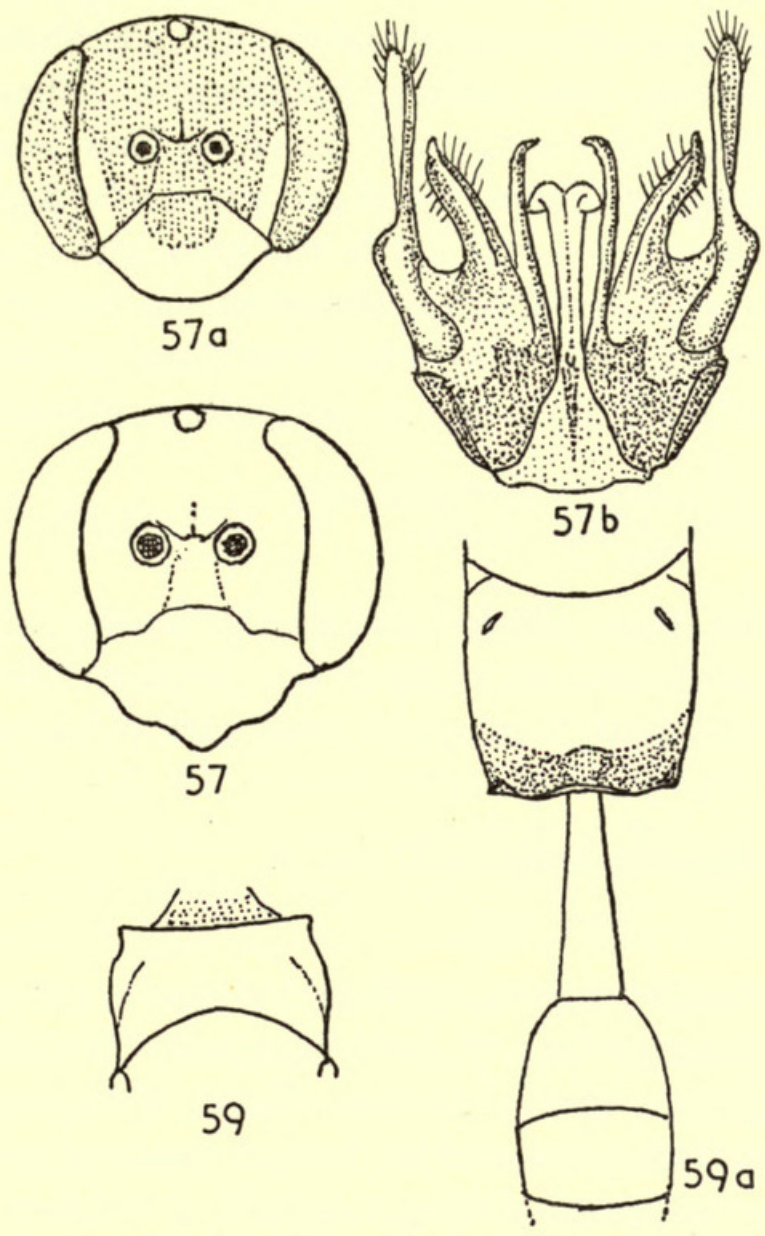

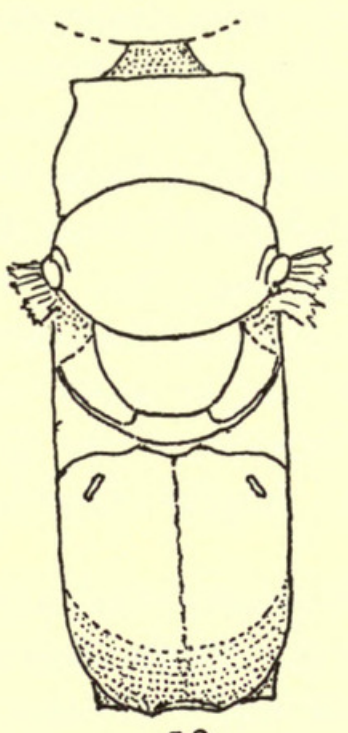

58

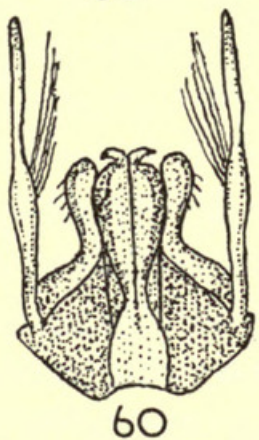

FIG. 57. Pseudagenia albosignata 9 , head, $\times$ I5. FIG. 57a. Pscudagenia albosignata $\hat{\delta}$, head, $\times \mathrm{I}_{5}$. FIg. 57b. Pseudagenia albosignata $\delta^{\star}$, genitalia, $\times c .45$. FIg. 58. Poecilagenia longicollis $ᄋ$, thorax, $\times$ 5. FIg. 59. Poecilagenia rugosa $\delta$, pronotum, $\times$ I2. FIg. 59a. Poecilagenia rugosa $\delta^{\star}$, epinotum and basal tergites, $\times$ I2. FIG. 6o. Paracyphononyx funebris $\delta$, genitalia, $\times 30$.

also with some longer, exserted, and white hairs. Postnotum shining, arcuately and transversely striate, depressed in the middle and as long as the metanotum. The rest of the thorax and the head dull, very finely reticulate-punctate (30 diameters), the epinotum also transversely rugulose, feebly so over the basal third. Tergites with a microscopic greyish pubescence.

Clypeus very convex, nearly half as wide again as long, the anterior margin convex. Inner orbits slightly convergent below, the interocular distance on the vertex equal to a trifle more than the length of the first two joints of the flagellum. Posterior ocelli twice as far from the eyes as from each other. Second joint of the flagellum five and a half times longer than wide and barely longer than the third.

Dorsum of the pronotum half as long as the mesonotum, the anterior face 
sub-vertical, the shoulders rounded. Scutellum very convex. Dorsum and declivity of the epinotum not distinctly delimited, the two parts forming a low arc in profile; the dorsal face with a shallow median longitudinal groove, the whole segment as long as wide. First tergite nearly twice as long as wide behind, and a little more than twice as wide there as at the base, the sides straight. Second abscissa of the radius twothirds longer than the first, the third two-fifths longer than the second; the nervulus almost interstitial with the basal vein.

ㅇ. $9 \mathrm{~mm}$. long. Face and clypeus entirely black; antennae fusco-ferruginous. Sixth tergite broadly triangular, flat, shining, and sparsely punctured. Otherwise like the $\sigma^{*}$ in colour, sculpture, and pubescence. Clypeus two-fifths wider than long, the anterior margin produced into a blunt triangular lobe. Face as wide below as on the vertex, where the interocular distance is equal to a very little less than the length of the first two joints of the flagellum. Posterior ocelli not quite twice as far from the eyes as from each other. Flagellum slender, the second joint five times longer than wide at the apex. First tergite wider caudad than in the $\delta$, only three-sevenths longer than wide behind. Otherwise like the $\hat{\sigma}$.

Adis Ababa, August-September I945, 2 ธేరే, I + ; Lekempti, Ethiopia, May I946, I $\sigma^{*}$.

Related to P. rubrirostris Arnold, from which it differs by the colour of the legs, the paler fasciae of the wings, and the more acute lobe of the clypeus. It also resembles $P$. amita Arnold, but is smaller, differently coloured, and with a less prominent lobe on the clypeus.

\section{Poecilagenia longicollis sp. $\mathrm{n}$.}

(FIG. 58)

ㅇ. $8.5 \mathrm{~mm}$. long. Head, pro-mesonotum, scutellum, metanotum, anterior half of the meso- and metapleura, and anterior legs, pale ferruginous. Posterior half of the mesopleura, the metapleura, epinotum, and abdomen, black. Middle and hind tibiae fusco-ferruginous. Antennae pale ferruginous at the base, becoming gradually darker to fuscous from the fifth joint onwards. Wings hyaline, with a pale fuscous cloud covering the basal third of the radial cell, distal half of the second cubital, proximal half of the third cubital cell, and the distal upper corner of the second discoidal cell. Mesopleura and posterior corner of the epinotum with decumbent silvery pubescence, the tergites with sparse, very fine and grey pubescence. Clypeus slightly shining, very shallowly punctured. Face dull, closely and finely reticulatepunctate, the vertex nitidulous and with a few punctures. Pronotum not quite dull, closely and transversely striate. Mesonotum transversely, the scutellum longitudinally and closely rugulose and nearly dull. Mesopleura obliquely, metapleura transversely rugose. Epinotum dull, coarsely reticulate-rugose, and with a fine median longitudinal carina. Abdomen shining and impunctate. Mandibles with a small tooth just behind the apex. Maxillary palpi long, the last three joints united fully as long as the first three joints of the flagellum. Clypeus nearly two and a third times wider than long, the apical margin convex. The interocular distance on the vertex is very little less than it is across the bottom of the eyes and is equal to the length of the first two joints of the flagellum. Posterior ocelli a little farther from 
the eyes than from each other. First joint of the flagellum half as long again as wide, the second joint three and three-fifths longer than wide at the apex, four-fifths longer than the third which is twice as long as wide. Dorsum of the pronotum widest across the míddle, twice as wide there as long, the anterior margin straight, the shoulders subrectangular. Mesonotum three-eighths longer than the pronotum. Scutellum and disk of the metanotum feebly convex. Postnotum shallow, in the middle one-third as long as the metanotum. Dorsum of the epinotum parallel-sided, about one-ninth wider at the base than long, the declivity about half as long as the dorsum and oblique. First tergite about one-fourth longer than wide at the posterior margin, and one-third longer than the second tergite.

Second abscissa of the radius twice as long as the first, a little longer than the third which is half as long as the fourth. Transverse anal vein of the hindwing prefurcal.

Aburi, Gold Coast, December I94I, I ㅇ.

Differs from P. reversa Bischoff by the longer pronotum and epinotum, narrower vertex, and paler red colour.

\section{Poecilagenia rugosa sp. $\mathrm{n}$.}

(FIGS. 59, 59a)

๙. $8 \mathrm{~mm}$. long. Head, pro- and meso-sternum, the middle third lengthwise of the epinotum, abdomen, coxae, trochanters, and the hind legs black. The thorax above and at the sides dark red. Apex of the mandibles ferruginous, the acute inferior edge of the scapes yellowish, the apical tergite pale yellow. Fore and middle legs, excepting the coxae and trochanters, fusco-ferruginous. Wings hyaline, with a pale brown cloud covering the greater part of the radial, second, and third cubital cells and the distal corner of the second discoidal cell. Clypeus and face with a short, coarse, and yellowish pubescence, the temples with long greyish pilosity. Dorsum of the thorax excepting the base of the epinotum and the pronotum nearly glabrous, the rest of the thorax and the coxae and trochanters with a coarse silvery pubescence intermixed with a long pilosity of the same colour, sufficiently dense to obscure the sculpture on the pronotum and epinotum. Abdomen with a decumbent, very fine and grey pubescence. Clypeus and face dull, strongly and closely punctured, the temples, vertex, and oçciput more sparsely so and not quite dull. Pronotum and mesopleura coarsely reticulate-rugose. Mesonotum dull, reticulate-punctate, the rugae thicker transversely, the scutellum and metanotum with a similar but larger sculpture. Postnotum half as long as the metanotal disk, with two or three costae on each side of the median depression. Metapleura obliquely costate. Epinotum very coarsely reticulate-rugose, the majority of the interspaces fully as wide as the ocelli. Hind coxae coarsely rugosopunctate and swollen at the base on the upper side.

Clypeus a little more than twice as wide as long, the anterior margin feebly convex. Antennal sockets twice as far from each other as from the eyes, in consequence of which the supra-antennal tubercle is wide. Interocular distance on the vertex equal to the length of the first four joints of the flagellum and one-fifth greater than across the base of the clypeus. Ocellar area tumid, the posterior ocelli as far from the eyes as from each other. Temples narrow. Scapes transversely compressed, with a sharp edge on the underside. First joint of the flagellum a little longer than wide, the 
second not quite twice as long as wide and as long as the third. Dorsum of the pronotum fairly convex transversely, two and a half times wider in the middle than long, the anterior margin nearly straight, the anterior face vertical, the shoulders subrectangular. Mesonotum twice as long as the pronotum. Scutellum convex transversely, as long as wide at the base. The dorsum and the very oblique declivity of the epinotum form a very low arc in profile; the whole segment is one-seventh wider at the base than long, and the sides are feebly convex. Abdomen clavate, the first tergite long and narrow, transversely compressed, the sides vertical and flat, three times longer than wide at the apical margin which is less than twice as wide as the base. The rest of the abdominal complex is narrow and five-sixths longer than the first tergite. The length of the first three abscissae of the radius are as 5:I2: Io. Cubitus of the hindwing interstitial with the transverse anal vein.

Diafarabé, French Sudan, 5 August I944, I ô.

This specimen is badly damaged, the head and pro-mesonotum being separated from the thorax, and parts of the legs are missing. However, objectionable as it is to base a new species on such specimens, I have done so in this case, as the species is so distinct from the other known males of the genus that it can be recognized without difficulty.

\section{Cyemagenia rubrozonata Cameron}

I9го, Sjöstedt's Kilimandjaro-Meru Exped. 8: 253.

Dilla and Haramaia, Ethiopia, April I948, I 우, 4 ธึోశ.

\section{Subfamily Pompilinae}

\section{Atopopompilus venans mlanjiensis Arnold}

1937, Ann. Transv. Mus. 19: 24.

Accra, Gold Coast, I3 July I94I, I ㅇ․

This specimen is an aberration in which the second and third abscissae of the radius are of about equal length. Otherwise it agrees in all respects with the type of the subspecies.

\section{Paracyphononyx affinis Haupt}

1929, Mitt. Zool. Mus. Berl. 15: I7o.

Aburi, Gold Coast, December I94I, I ô.

Paracyphononyx difficilis Bischoff

1913, Arch. Naturgesch. 79: 55.

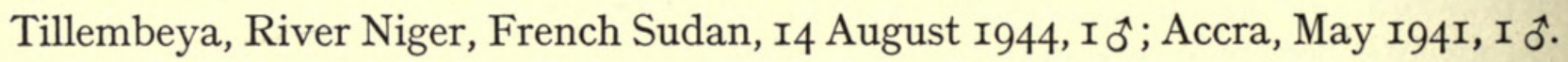

\section{Paracyphononyx laboriosus Arnold}

1936, Ann. Transv. Mus. 18: 438 .

Asba Tafari, Ethiopia, 7,800 ft., September I945, I ㅇ․

\section{Paracyphononyx metemmensis Magretti}

1884, Ann. Mus. Stor. Nat. Genova, 21: 565 .

Tillembeya, River Niger, French Sudan, August I944, I ơ; Accra, Gold Coast, December I94I, I ô. 
Paracyphononyx funebris sp. $\mathrm{n}$.

(FIG. 60)

§. $7 \cdot 5-9 \cdot 5 \mathrm{~mm}$. long. Black. Flagellum ferruginous below, brownish-black above, scape dirty yellow on the underside. Wings fuscous. Clypeus, face, and underside of the coxae with greyish-silvery pubescence, the head and pronotal collar also with black, erect hairs. Epinotal declivity and base of the first tergite with a dense, coarse, erect whitish pubescence, the extreme base of the second, third, and fourth tergites with a decumbent bluish-grey bloom. Sixth tergite white.

Clypeus nearly two and a half times wider than long, separated from the bottom of the eyes by a length equal to two-thirds of the cheeks. Interocular distance on the vertex very slightly less than the interocular distance across the base of the clypeus, and equal to the length of the first two joints of the flagellum plus two-thirds of the third joint. The fourth to eleventh joints of the flagellum are dilated below near the base, and the second joint is a little shorter than the third. Posterior ocelli two-thirds farther from each other than from the eyes. Pronotum two and a half times wider across the posterior angles than long. Dorsum of the epinotum twice as wide at the base as long, twice as long as the declivity, the junction of the two faces rounded. First tergite as long as wide behind. First abscissa of the radius a little longer than the second; third cubital cell petiolate, the petiole variable in length, but sometimes as long as the second abscissa of the radius.

Haramaia, Ethiopia, May I948, on Myosotis flowers, I9 oto.

Related to difficilis Bischoff, from which it differs by the colour of the legs, the darker wings, wider clypeus, and the genitalia. In the latter the outer paramera are not spatulate as in difficilis, but narrow and strap-like, with six long hairs emitted from about the middle of the inner margin.

\section{Paracyphononyx zonatus Illiger}

1802, Mag. Insektenkunde, 1: 193.

Diafarabé, French Sudan, I4 August I944, I ot.

A slight variety with the outer paramera of the genitalia narrower in the middle.

In addition to the species listed above, the collection contains seven females, representing two or three species of the genus Paracyphononyx, which do not agree with any of the species known to me. It would be unwise to describe these as new in the absence of specimens which could be indubitably considered the opposite sex. In this genus the males can easily be determined by the genitalia, but the females are far more difficult to determine.

\section{Episyron histrio Lepeletier}

1845, Hist. Nat. Ins. Hymén, 3: 440.

Tillembeya, River Niger, French Sudan, I4 August I944, I 9 ; Abbai Gorge and River Didessa, Ethiopia, 23 October I945, 25 August I946, I + , I $\$$.

The specimen from the Didessa, II mm. long, is not only larger than the typical of of the species but differs considerably in colour, the first four abdominal segments being 
black, excepting the yellow bands on the second and third tergites. The genitalia, however, are identical.

\section{Batazonellus capensis Dahlbom}

I843, Hymen. Eur. 1: 49.

Batazonellus Arnold, 1937, Ann. Transv. Mus. 19: I.

Lake Bishoftu, Ethiopia, I2 May I946, I +.

\section{Schistonyx umbrosus Klug}

1834, Symb. phys., Dec. 4, T. 39, F. 4.

Dakar, Senegal, I August I945, 2 웅․

\section{Elaphrosyron insidiosus Smith}

1879, Descr. new sp. Hymen.: 143.

Kaolack, Senegal, I 우 ; Diafarabé, French Sudan, I 우; Dilla, Ethiopia, 2 đేో

\section{Characters}

GUICHARDIA gen. $n$.

๙. Palpi short, the last three joints of the maxillary palpi not more than three times longer than wide. Labrum exposed. Mandibles with a tooth behind the apex. Clypeus feebly convex, as wide as the bottom of the face. Cheeks very short. Face without a supra-antennal tubercle. Occiput not concave, its junction with the vertex rounded. Pronotum not much shorter than the mesonotum, convex lengthwise. Lateral margins of the mesonotum feebly reflexed posteriorly. Sides of the scutellum steep, raised above the level of the metanotum. Postnotum linear. Dorsum of the epinotum convex lengthwise and transversely, forming in profile a low and unbroken arc with the very short declivity, its posterior angles dentiform. Apical ventral valve produced into a long spine. Femora of the trachyscelid type. Claws bifid, the pulvillus small and with about ten short cilia. Wings with three cubital cells, the third much wider on the cubitus than on the radius; nervulus slightly prefurcal. Cubitus of the hindwing emitted a little beyond the end of the submedial cell, the basal lobe small.

Genotype: G. macilenta Arnold.

The subdentate posterior angles of the epinotal dorsum are very similar to those of Epiclinotus Haupt, but the wide clypeus and the rounded junction of the slightly convex occiput with the vertex show that the genus belongs to the tribe Pompilini.

\section{Guichardia macilenta sp. n.}

$$
\text { (FIGS. 6I, 6I } a-d \text { ) }
$$

o. I0.5-II mm. long. Black. Head and thorax with a fine, decumbent grey pubescence and without erect pilosity. First three abdominal segments (or four in the paratype) with a dense, long, greyish-silvery pubescence, the remaining segments with a thin black pubescence and some longer and erect black hairs. Wings almost hyaline over the basal fourth, the rest moderately fuscous with traces of darker clouds over the basal vein area and the radial and second cubital cells. Clypeus 
two-thirds wider than long, the lateral margins long, the anterior margin straight. Inner orbits parallel below, slightly divergent above the middle and convergent on the vertex, the interocular distance there no greater than across the base of the clypeus, and equal to the length of the second and third joints of the flagellum united. Posterior ocelli slightly nearer to the eyes than to each other. Second joint of the flagellum as long as the third, and nearly two and a half times longer than wide.
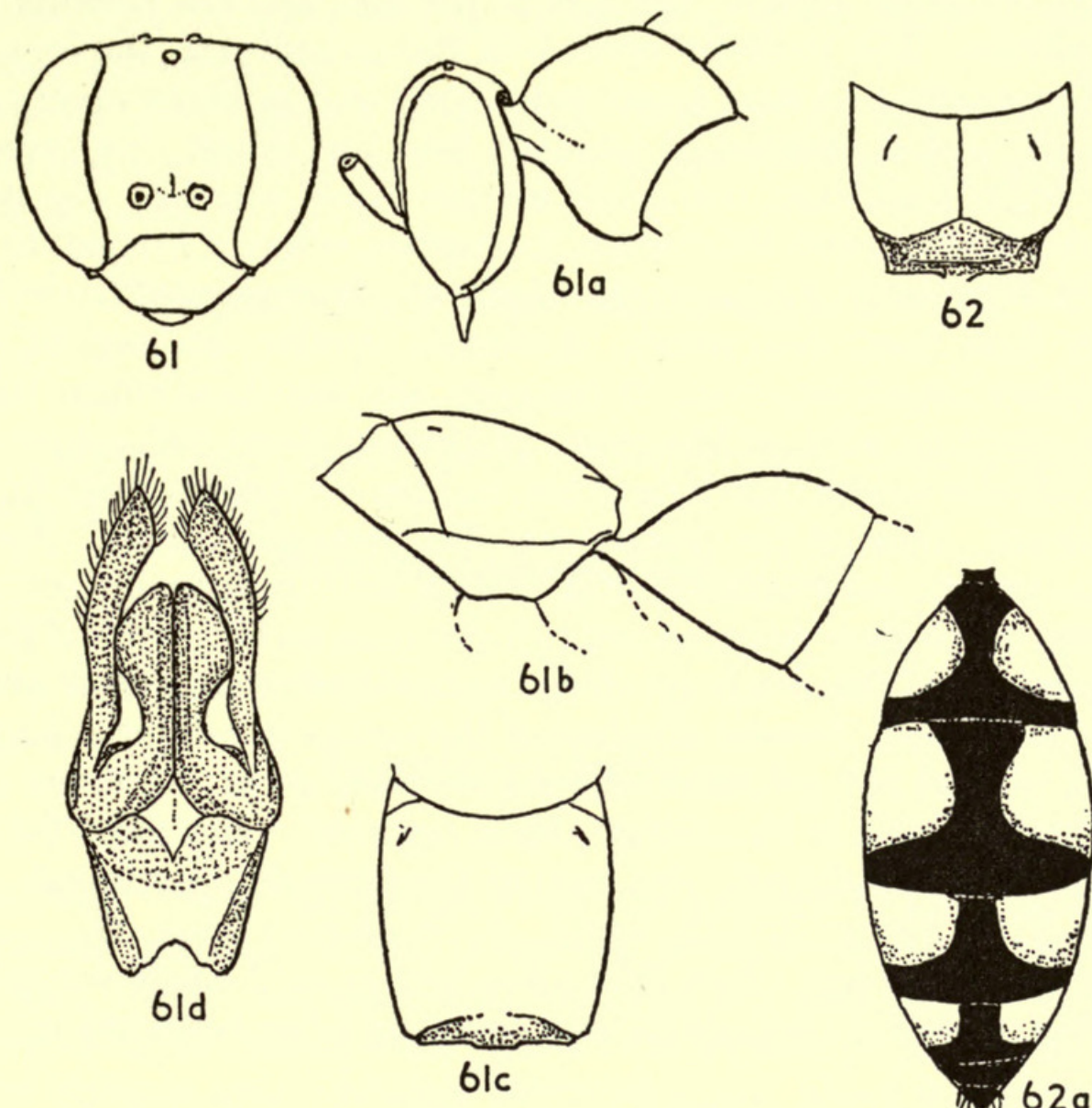

FIG. 6I. Guichardia macilenta ${ }^{*}$, head, $\times$ I2. FIg. 6Ia. Guichardia macilenta, head and pronotum, $\times$ I2. FIG. 6I b. Guichardia macilenta, epinotum and first tergite, $\times$ I2. FIG. 6Ic. Guichardia macilenta, epinotum, $\times$ I2. FIG. 6Id. Guichardia macilenta, genitalia, $\times 27$. FIG. 62 . Anoplius octomaculatus +, epinotum, $\times 6$. Fig. 62a. Anoplius octomaculatus, abdomen, $\times 6$.

Pronotum convex lengthwise, seven-ninths wider across the posterior angles than long in the middle, moderately narrowed cephalad, the hind margin obtusely angular. The horizontal part of the scutellum one-fifth longer than wide, and about three times longer than the metanotal disk. Epinotum moderately convex lengthwise and transversely, about one-eighth longer than wide at the base, the lateral margins convex; the dorsum is about four times longer than the very oblique declivity, its posterior angles subdentiform. Abdomen narrow, the first tergite about one-seventh longer than wide at the apical margin. First and third abscissae of the radius of equal length, and half as long as the second. The third cubital cell three and twothirds wider on the cubitus than on the radius; both recurrent veins meet the second and third cubital cells a little beyond the middle.

Agogo, Gold Coast (type), 30 January I942; Aburi, Gold Coast, 2I January I94I. 


\section{Anoplius octomaculatus sp. $\mathrm{n}$.}

(FIGS. 62 and 62a)

ㅇ. I $5 \mathrm{~mm}$. long. Black. First four tergites with large yellowish-red maculae on each side. Wings dark fuscous. Clypeus with a sparse grey pubescence, the face with a small patch of silvery pubescence on each side, adjacent to the eyes and at about the level of the antennal sockets, the rest of the face and the temples with a very sparse black pilosity. The posterior corners of the mesopleura, the inner half of the upperside of the middle and hind coxae with dense and brilliant silvery pubescence. The setae on the apical abdominal segment long and black. Clypeus two and a quarter times wider than long, the apical margin feebly convex. The inferior interocular distance a little greater than across the vertex, where it is equal to slightly less than the length of the second joint of the flagellum. Posterior ocelli one-third farther from the eyes than from each other. Antennae slender, the second joint of the flagellum six times longer than wide at the apex and one-third longer than the third joint. Temples half as wide as the eyes. Pronotum three and a half times wider between the posterior angles than long in the middle. Scutellum three-fourths as long as the mesonotum. Disk of the metanotum flat, truncate behind. Postnotum depressed, half as long as the metanotal disk, shining and transversely striate. Dorsum of the epinotum more than twice as wide at the base as long, with a median longitudinal impressed line, the declivity steep, compressed at the sides and not much shorter than the dorsum. Second abscissa of the radius five-eighths longer than the first, the third cubital cell petiolate, the petiole very short, or about one-fifth the length of the first abscissa of the radius. Both recurrent veins meet the cubital cells beyond their middle. Transverse anal vein of the hindwing postfurcal.

Tillembeya, River Niger, French Sudan, 26 September I944, I 9.

Not closely related to any other Ethiopian species, and easily recognized by the silvery pubescence on the mesopleura and coxae and the large red maculae on the tergites.

\section{Anoplius successor Cameron}

I9Iо, Sjöstedt's Kilimandjaro-Meru Exped. 8: 25 I.

A. subfasciatus Arnold, 1937, Ann. Transv. Mus. 19: 63.

River Didessa, May I946, and Debra Sina, Ethiopia, September I945, 2 웅․ The specimen from Debra Sina is a slight variety in which the wings are darker and the pubescence entirely black.

I855, Cat. Hymen. B.M. 3: I40.

\section{Anoplius morosus Smith}

Akaki and Asba Tafari, Ethiopia, February I948, I ㅇ, 2 бో

I76I, Fauna Suec. ed. 2: 4I2.

\section{Anoplius fuscus L.}

Arnold, 1937, Ann. Transv. Mus. 19: 65 .

In my monograph of the Ethiopian Pompilidae I remarked on the variability of this species in the Ethiopian region and named some varieties. There are four specimens in the collection, from different parts of Ethiopia, of which one agrees with the 
var. acutiangulus Cameron, and the others differ only in a minor degree from the varieties montivagus, johannis, and brachcerus Arnold. It would serve no useful purpose to give names to these specimens since the variations grade one into another.

I 787, Mant. Ins. 1: 278 .

\section{Pompilus plumbeus Fabricius}

Labadi, Gold Coast ; Fatick, Senegal; Tillembeya, River Niger, French Sudan, and River Hawash, Ethiopia, I ô, 4 우.

The specimens from Fatick and Hawash represent a slight variety in which the first four joints of the anterior tarsi and the second to fourth of the middle and hind tarsi are yellowish-red.

Pompilus rutilus Klug subsp. lutarius Saussure

I834, Symb. phys. 4: T. 38 .

Saussure, 1891, Mitt. Schweiz. Ent. Ges. 81: 265.

Accra and Labadi, Gold Coast ; Tillembeya, River Niger, French Sudan; Diafarabé, French Sudan, 3 우우, 8 중․

\section{Pompilus cinnamomeus Arnold}

1937, Ann. Transv. Mus. 19: 52 .

Accra, Gold Coast, September I94I, 6 우우.

\section{Pompilus contrarius sp. $n$.}

(FIG. 63)

‥ $8.5 \mathrm{~mm}$. long. Head and thorax black, the anterior half of the clypeus and the neck and lateral margins of the pronotum, flavo-ferruginous. Mandibles ferruginous, the apex black. Abdomen and legs pale ferruginous, antennae fusco-ferruginous. Wings hyaline, tinged with yellow; the forewing beyond the cells, but not including the extreme apical margin, faintly fuscous. Head and thorax with a dull white decumbent pubescence, long and dense on the epinotum where it is arranged in close transverse rows directed laterad on each side of the middle line; below the pubescence there are traces of transverse striae. Clypeus two and a half times wider than long, the apical margin shallowly concave. Inner orbits parallel, slightly convergent on the vertex. Interocular distance at the base of the eyes one-fifth greater than on the vertex, where it is equal to the length of the first two joints of the flagellum plus one-sixth of the third joint. Posterior ocelli three-fifths farther from each other than from the eyes. Flagellum slender, the second joint nearly five and a half times longer than wide at the apex. Pronotum about two and a third times wider than long (measured tangentially), the hind margin arcuate. Postnotum onefourth as long in the middle as the metanotal disk, transversely striate. Epinotum with a fine median longitudinal carina, the dorsum gibbous, merging gradually into the steep declivity which is about twice as long as the dorsum, and flat. The dorsum is three times wider than long. The proportions of the first three abscissae of the radius are as $3: I I: 8$; the third cubital cell is twice as long on the cubitus as on the radius. Transverse anal vein of the hindwing prefurcal. 
Tillembeya, River Niger, French Sudan, I4 August I944, I ㅇ.

Easily recognized by the peculiar arrangement of the pubescence of the epinotum and its flattened and wide declivity.
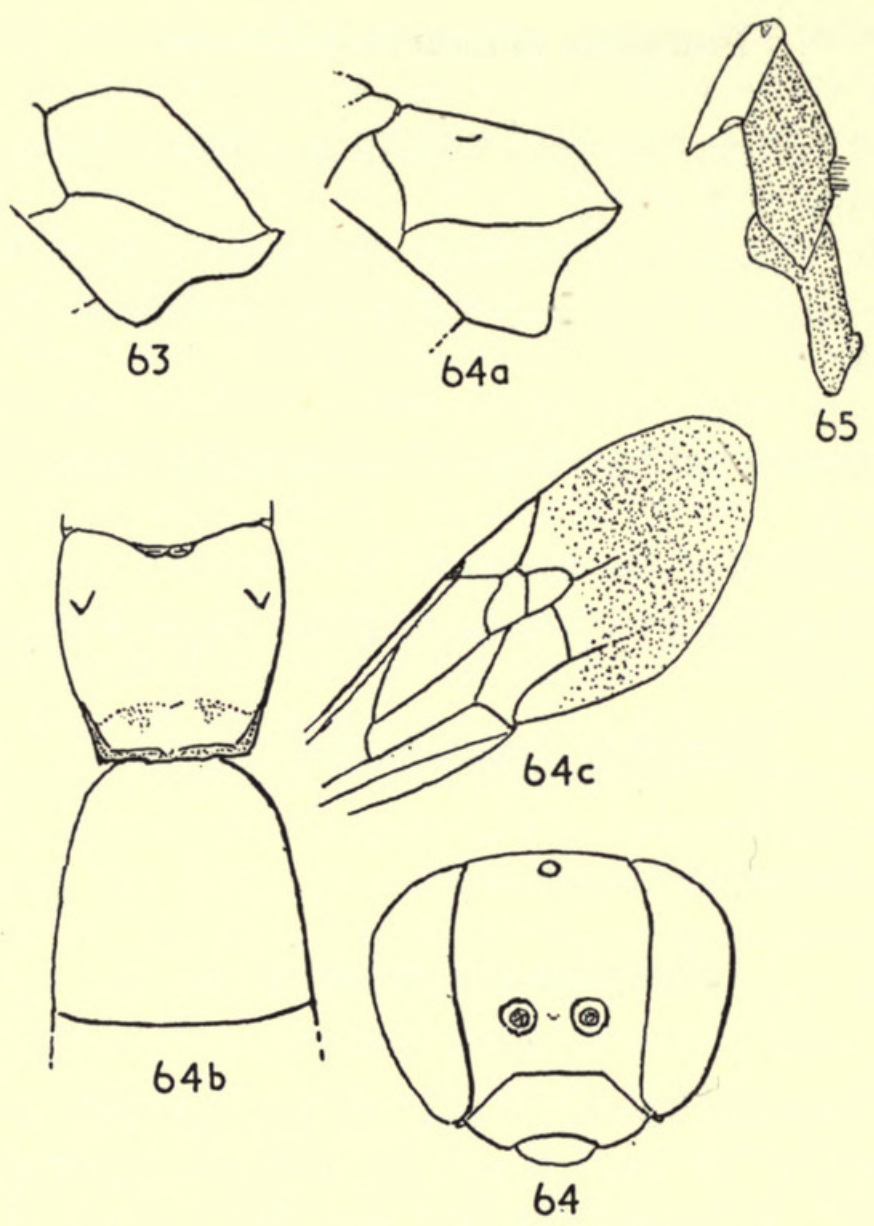

FIg. 63. Pompilus contrarius 우, epinotum, $\times$ c. 15. Fig. 64. P. (Pilompus) levis ㅇ, head, $\times$ c. I5. FIg. 64a. P. (Pilompus) levis, epinotum, $\times$ c. I5. FIg. 64b. P. (Pilompus) levis, epinotum and first tergite, $\times$ c. I5. FIg. 64c. P. (Pilompus) levis, wing, $\times$ I2. FIg. 65. Ceropales variolosus $\hat{\sigma}^{2}$ left stipes, dorsal view, $\times 27$.

\section{Characters}

\section{PILOMPUS subgen. n. (anagram Pompilus)}

ㅇ. Anterior tarsi without a comb, all the claws bifid, the pulvillus small with a comb of about nine cilia. Clypeus not strap-like and much wider than long as in Pompilus, but narrow, more or less hexagonal (Fig. 64), and as wide as the bottom of the face. First tergite wide at the base, not much narrower there than at the apex. Otherwise like Pompilus.

Subgenotype, P. levis Arnold.

\section{Pilompus levis sp. $\mathrm{n}$.}

$$
\text { (FIGs. 64, 64a-c) }
$$

․ $8.5 \mathrm{~mm}$. long. Black. Palpi ochreous. Wings hyaline, the forewing beyond the cells pale fuscous. Head, thorax, and legs with a very fine pruinose pubescence; the 
basal two-thirds of the first tergite and the basal half, more or less, of the second to fourth tergites with a similar pubescence. Clypeus two and a third times wider than long, the anterior margin concave and twice as long as the lateral margins. Palpi short. Inner orbits divergent over the middle third of their length. Interocular distance on the vertex equal to the length of the first two joints of the flagellum plus one-third of the third joint. Posterior ocelli twice as far from each other as from the eyes. Flagellum fairly stout, the second joint barely three times longer than wide at the apex and as long as the third joint.

Occiput nearly flat, its junction with the vertex widely rounded. Pronotum twice as wide behind as long in the middle, the hind margin obtusely angular, the dorsal and anterior face forming an unbroken arc in profile. Mesonotum as long as the pronotum. Postnotum about half as long in the middle as the feebly convex metanotal disk, linear at the sides. Epinotal dorsum widest across the middle, sevenninths wider there than long, nearly twice as long as the oblique declivity which is nearly flat transversely. First tergite as long as wide behind, only three-fourths wider there than at the base. Anterior tarsi with a few short spines on the outside; posterior tibiae with two rows of three spines each on the upperside. Third cubital cell petiolate, the petiole half as long as the second abscissa of the radius; the proportions of the three abscissae are as 6:4: Io. First transverse cubital vein strongly curved inwards, the pterostigma very small, the nervulus postfurcal. Transverse anal vein of the hindwing slightly prefurcal.

Aburi, Gold Coast, December I94I, I 우.

Subfamily Ceropalinae

Ceropales variolosus Arnold

1947, Ann. Transv. Mus. 19: 87, ㅇ.

(FIG. 65)

t. $7.5 \mathrm{~mm}$. long (hitherto undescribed). Sixth and seventh abdominal segments yellow. Puncturation of the face less close than in the $q$, the punctures arranged in transverse rows, the spaces between the rows about twice as wide as the punctures. Clypeus two and a half times wider than long. The proportions of the first three abscissae of the radius are as 5:II:I5. The outer paramera of the genitalia have the shape of a flattened fish-hook, with the acute, triangular, and transparent barb on the inside.

Accra, Gold Coast, September I94I, 2 ડૈరే, I 우 ; Diafarabé, French Sudan, August I944, I 우.

The colour is variable. In the other $\delta$ specimen and in the $q$ from Diafarabe the red parts of the head and thorax are replaced with black.

\section{Ceropales latifasciatus Arnold}

1937, Ann. Transv. Mus. 19: 92.

Lekempti, Haramaia, and Cencia, Ethiopia, April-May r948, 3 ऽేశ.

ENTOM. 2. 3 


\section{$2 \mathrm{BHL}$ Biodiversity Heritage Library}

Arnold, George. 1951. "Sphecidae and Pompilidae (Hymenoptera) collected by Mr. K. M. Guichard in West Africa and Ethiopia, 1941-1948." Bulletin of the British Museum (Natural History) Entomology 2, 95-183.

https://doi.org/10.5962/bhl.part.27752.

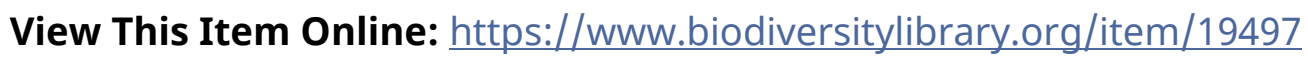

DOI: https://doi.org/10.5962/bhl.part.27752

Permalink: https://www.biodiversitylibrary.org/partpdf/27752

\section{Holding Institution}

Natural History Museum Library, London

\section{Sponsored by}

Natural History Museum Library, London

\section{Copyright \& Reuse}

Copyright Status: In copyright. Digitized with the permission of the rights holder.

Rights Holder: The Trustees of the Natural History Museum, London

License: http://creativecommons.org/licenses/by-nc-sa/4.0/

Rights: http://biodiversitylibrary.org/permissions

This document was created from content at the Biodiversity Heritage Library, the world's largest open access digital library for biodiversity literature and archives. Visit BHL at https://www.biodiversitylibrary.org. 